\title{
Expressão dos antígenos PspA1 e PspA3 de Streptococcus pneumoniae em bactérias lácticas.
}

\author{
Ivana Barros de Campos
}

Dissertação de Mestrado apresentada ao Programa de Pós-Graduação Interunidades em Biotecnologia USP/ Instituto Butantan/ IPT, para obtenção do Título de Mestre em Biotecnologia.

São Paulo 


\title{
Expressão dos antígenos PspA1 e PspA3 de Streptococcus pneumoniae em bactérias lácticas.
}

\author{
Ivana Barros de Campos
}

Dissertação de Mestrado apresentada ao Programa de Pós-Graduação Interunidades em Biotecnologia USP/ Instituto Butantan/ IPT, para obtenção do Título de Mestre em Biotecnologia.

Área de Concentração: Biotecnologia

Orientador:

Dr. Paulo Lee Ho

São Paulo 
DADOS DE CATALOGAÇÃO NA PUBLICAÇÃO (CIP)

Serviço de Biblioteca e Informação Biomédica do

Instituto de Ciências Biomédicas da Universidade de São Paulo

reprodução não autorizada pelo autor

\section{Campos, Ivana Barros.}

Expressão dos antígenos PspA1 e PspA3 de Streptococcus pneumoniae em bactérias lácticas / Ivana Barros Campos. -- São Paulo, 2006.

Orientador: Paulo Lee Ho.

Dissertação (Mestrado) - Universidade de São Paulo. Instituto de Ciências Biomédicas. Programa de Pós-Graduação Interunidades em Biotecnologia USP/Instituto Butantan/IPT. Área de concentração: Biotecnologia. Linha de pesquisa: Desenvolvimento de vacinas.

Versão do título para o inglês: Expression of PspA1 and PspA3 antigens of Streptococcus pneumoniae in lactic bacteria.

Descritores: 1. Lactobacillus 2. Lactococcus 3. Streptococcus 4. Biologia molecular 5. Engenharia genética 6 . Formação de anticorpos I. Ho, Paulo Lee II. Universidade de São Paulo. Instituto de Ciências Biomédicas. Programa de Pós-Graduação em Biotecnologia III. Título. 
Universidade de São Paulo, Instituto Butantan, Instituto de Pesquisas Tecnológicas

Candidato(a): $\quad$ Ivana Barros Campos.

Título da Dissertação: $\quad$ Expressão dos antígenos PspA1 e PspA3 de Streptococcus pneumoniae em bactérias lácticas .

Orientador(a): $\quad$ Paulo Lee Ho.

A Comissão Julgadora dos trabalhos de Defesa da Dissertação de Mestrado, em sessão pública realizada a .$/ \ldots$ considerou
( ) Aprovado(a)
( ) Reprovado(a)

Examinador(a): Assinatura:

Nome:

Instituição:

Examinador(a): Assinatura:

Nome:

Instituição:

Examinador(a): Assinatura:

Nome:

Instituição: 


\section{CERTIFICADO}

Certificamos que o Protocolo para uso de animais em experimentação $n^{\circ} 179 / 04$, sobre o projeto intitulado "Desenvolvimento de vacinas recombinantes contra Pneumococo, DPT e Schistosoma", sob a responsabilidade de Luciana Cezar Cerqueira Leite está de acordo com os Princípios Éticos na Experimentação Animal adotado pelo Colégio Brasileiro (COBEA) e foi aprovado pela COMISSÃO DE ÉTICA NO USO DE ANIMAIS DO INSTITUTO BUTANTAN (CEUAIB) em reunião de $09 / 11 / 2004$.

São Paulo, 17 de novembro de 2004.

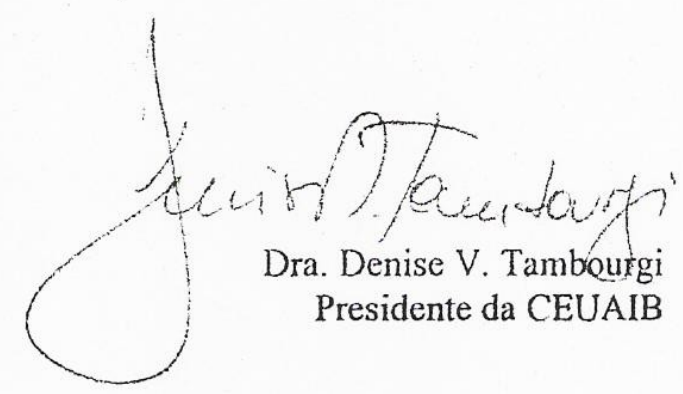




\section{AGRADECIMENTOS}

Ao Dr. Paulo Lee Ho, pela ótima oportunidade de trabalhar neste projeto e no Instituto Butantan, pela amizade e pela confiança em mim depositada.

À Dra. Maria Leonor Sarno Oliveira, pelos ensinamentos, pela paciência e pela indispensável ajuda do começo ao fim do projeto.

À Karina Araújo Aires, pelas inestimáveis “luzes no fim do túnel”.

Aos companheiros de laboratório, pela amizade e alegria de trabalhar a cada dia, mesmo quando algo não dá certo.

À Fapesp, pelo auxílio financeiro.

E não menos importante, à minha família pelo grande apoio, e ao Israel pelo apoio e paciência nos momentos mais difíceis. 


\section{RESUMO}

Campos IB. Expressão dos antígenos PspA1 e PspA3 de Streptococcus pneumoniae em bactérias lácticas (dissertação). São Paulo: Instituto de Ciências Biomédicas da Universidade de São Paulo; 2005.

Streptococcus pneumoniae é um importante patógeno respiratório que causa pneumonia, meningite e otite média. A vacina atualmente utilizada, composta de polissacarídeos capsulares (PS) derivados de 23 sorotipos diferentes, tem pouca eficácia em crianças, idosos e em pacientes imunocomprometidos. Vacinas com PS conjugados à proteína são mais eficientes, mas sua produção tem alto custo para ser amplamente utilizada. Além disso, o aumento de isolados clínicos de S. pneumoniae resistentes à antibióticos suporta o desenvolvimento de uma nova e mais eficiente vacina. $\mathrm{O}$ uso de bactérias ácido-lácticas (LAB) recombinantes vivas, como um sistema de apresentação do antígeno, representa uma estratégia promissora de vacinação de mucosa, já que são bactérias geralmente consideradas seguras (GRAS-status) e capazes de induzir resposta imune sistêmica e de mucosa. Neste trabalho, Lactococcus lactis, Lactobacillus casei e Lactobacillus helveticus foram engenheirados para expressão constitutiva de PspA (proteína A de superfície de pneumococo), um importante fator de virulência de $S$. pneumoniae. As bactérias recombinantes foram capazes de expressar PspA em duas localizações celulares: intracelular ou ancorada à parede celular, como analisado por Western-blot, utilizando anticorpos policlonais produzidos contra PspA recombinante purificada de E. coli. A estimulação humoral do sistema imune foi avaliada em termos de produção de anticorpos anti-PspA do tipo IgG no soro ou do tipo IgA na saliva, após administração intranasal de LABs recombinantes em camundongos.

Palavras-chave: Streptococcus pneumoniae; PspA; bactérias lácticas; lactobacilos; imunização de mucosa. 


\begin{abstract}
Campos IB. Expression of Streptococcus pneumoniae PspA1 and PspA3 antigens in lactic bacteria (dissertation). São Paulo: Instituto de Ciências Biomédicas da Universidade de São Paulo; 2005.

Streptococcus pneumoniae is an important respiratory pathogen that causes pneumonia, meningitis and otitis media. The current vaccine in use is composed of capsular polysaccharides (PS) derived from 23 different serotypes, and has little efficacy in young children, elderly and in patients with immunodeficiencies. PS-protein conjugate vaccines are more effective, but their production is expensive for widespread use. Moreover, the increase in antibiotic-resistant S. pneumoniae clinical isolates supports the development of new and more effective vaccines. The use of live recombinant lactic acid bacteria (LAB) as antigen delivery and presentation systems represents a promising strategy for mucosal vaccination, since they are generally regarded as safe bacteria (GRAS-status) and are able to elicit both systemic and mucosal immune responses. In this work, Lactococcus lactis, Lactobacillus casei and Lactobacillus helveticus were engineered for constitutive expression of PspA (Pneumococcal Surface Protein A), an important S. pneumoniae virulence factor. Recombinant bacteria were able to express PspA in two cellular locations: intracellular or cell-surface exposed, as analyzed by Western-blot, using polyclonal antibodies produced against recombinant PspA purified from E. coli. Stimulation of humoral immune system was evaluated in terms of production of anti-PspA IgG in the sera or IgA in saliva, after intranasal administration of recombinant LAB in mice.
\end{abstract}

Key-words: Streptococcus pneumoniae; PspA; lactic bacteria; lactobacillus; mucosal immunization. 


\section{LISTA DE ABREVIATURAS E SIGLAS}

$\mathrm{AB}$ - fragmento de PspA correspondente à região $\mathrm{AB}$

Abs - Absorbância

$\mathrm{bp}$ - pares de base

BSA - Albumina de soro bovino

CBP - Proteínas ligadoras de colina

CDC - (“Centers for Disease Control and Prevention”) Centros de controle e prevenção de doenças dos Estados Unidos

CFU - Unidade formadora de colônia

CWH - hidrolase de parede celular

DNA - Ácido desoxiribonucleíco

dNTP - deoxinucleotídeos trifosfato

DO - Densidade óptica

E. coli-Escherichia coli

ELISA - "Enzyme Linked Immunosorbent Assay"

FB - Fator B do complemento

Forw - (“Forward") Oligonucleotídeo que se anela no sentido 5' do gene

GRAS-status - (“Generally Recognized As Safe”) Bactérias geralmente consideradas seguras

H. pylori-Helicobacter pylori

HIV - Vírus da imunodeficiência humana

Ig - Imunoglobulina

IFN - Interferon

IL - Interleucina

$\mathrm{kDa}$ - Kilo Dalton

L. acidophilus - Lactobacillus acidophilus

L. brevis - Lactobacillus brevis

L. casei-Lactobacillus casei

L. delbrueckii-Lactobacillus delbrueckii

L. fermentum - Lactobacillus fermentum

L. helveticus - Lactobacillus helveticus

L. johnsonii - Lactobacillus johnsonii 
L. lactis - Lactococcus lactis

L. plantarum - Lactobacillus plantarum

L. reuteri-Lactobacillus reuteri

L. rhamnosus - Lactobacillus rhamnosus

LAB - Bactérias ácido-lácticas

LB - Meio de cultura Luria-Bertani para E. coli

LC-Lactobacillus casei

LH - Lactobacillus helveticus

LL - Lactococcus lactis

M17 - Meio de cultura para lactococos

MIC - Concentração mínima inibitória

MRS - Meio de cultura para lactobacilos

OPD - o-fenilenodiamina

PCR - Reação em cadeia da polimerase

$\mathrm{PdB}$ - toxóide genético da pneumolisina

"pellet" - precipitado após centrifugação

Ply - Pneumolisina

PsaA - Adesina A de superfície de pneumococo

PspA - Proteína A de superfície de pneumococo

S. pneumoniae - Streptococcus pneumoniae

SDS - Dodecil sulfato de sódio

SDS-PAGE - Eletroforese em gel de poliacrilamida com SDS

TTFC - Fragmento $\mathrm{C}$ da toxina tetânica

WHO - (“World Health Organization”) Organização Mundial da Saúde 


\section{LISTA DE ILUSTRAÇÕES E TABELAS}

\section{Figuras}

Figura 1 - Esquema de PspA na superfície de pneumococo .............................................. 09

Figura 2 - Esquema das regiões de $p s p A$ correspondentes à estrutura da proteína PspA .... 11

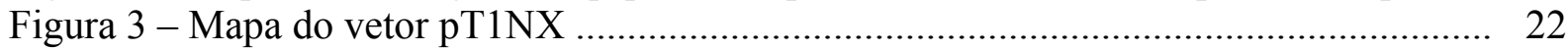

Figura 4 - Mapa do vetor pT1NxssAnch ....................................................................... 22

Figura 5 - Foto do gel de agarose com os fragmentos $p s p A 1$ ' e $p s p A 3$ ' para construção

intracelular

Figura 6 - Foto do gel de agarose com os fragmentos $p s p A 1$ ' e $p s p A 3$ ' para construção de

ancoramento à parede

Figura 7 - Foto do gel de agarose com o fragmento $a b 1$

Figura 8 - Foto do gel de agarose com o fragmento $a b 3$

Figura 9 - Foto do gel de agarose das reações de digestão dos vetores de clonagem para

obtenção dos fragmentos $p s p A 1$ ' e $p s p A 3$ ' para construção intracelular

Figura 10 - Foto do gel de agarose das reações de digestão dos vetores de clonagem para

obtenção dos fragmentos abl e ab3

Figura 11 - Foto do gel de agarose das reações de digestão do vetor de expressão e dos

vetores de clonagem para obtenção dos fragmentos $p s p A 1$ ' e $p s p A 3$ ' para

construção de ancoramento à parede

Figura 12 - Foto do gel de agarose dos PCRs de clones de L. lactis portando os genes

pspA1' e $p s p A 3$ ' para expressão intracelular

Figura 13 - Foto do gel de agarose dos PCRs de clones de L. lactis portando os genes abl

e $a b 3$

Figura 14 - Foto do gel de agarose dos PCRs de clones de L. lactis portando os genes

pspA1' e $p s p A 3$ ' para expressão de ancoramento à parede

Figura 15 - Western-blot dos lisados de todas as bactérias transformadas expressando as

proteínas PspA1' e AB1 no meio intracelular....

Figura 16 - Western-blot dos lisados de todas bactérias transformadas expressando as

proteínas PspA3' e AB3 no meio intracelular

Figura 17 - Western-blot dos lisados dos clones de L. lactis expressando as proteínas

PspA1' e PspA3' ancoradas à parede celular

Figura 18 - Western-blot dos lisados dos clones de L. casei expressando as proteínas

PspA1' e PspA3' ancoradas à parede celular

Figura 19 - Western-blot do meio de cultura de L. lactis expressando as proteínas

heterólogas no meio intracelular

Figura 20 - Western-blot do meio de cultura de L. lactis expressando as proteínas

heterólogas ancoradas à parede celular

Figura 21 - Western-blot do meio de cultura de L. casei expressando as proteínas

heterólogas no meio intracelular

Figura 22 - Western-blot do meio de cultura de L. casei expressando as proteínas 
heterólogas ancoradas à parede celular

Figura 23 - Western-blot do meio de cultura de L. helveticus expressando as proteínas

heterólogas ancoradas à parede celular

Figura 24 - Gráfico da análise da exposição das proteínas de interesse em L. lactis .....

Figura 25 - Gráfico da análise da exposição das proteínas de interesse em $L$. casei ........... 45

Figura 26 - Gráfico das curvas de crescimento de L. lactis recombinantes ......................... 46

Figura 27 - Gráfico das curvas de crescimento de $L$. casei recombinantes ........................ 46

Figura 28 - Gráfico das curvas de crescimento de L. helveticus recombinantes .................. 47

Figura 29 - Gráfico das diluições seriadas de L. lactis recombinantes em diferentes DOs .. 48

Figura 30 - Gráfico das diluições seriadas de L. casei recombinantes em diferentes DOs ... 48

Figura 31 - Gráfico das diluições seriadas de L. helveticus recombinantes em diferentes

DOs

Figura 32 - Western-blot da quantificação de AB3 e PspA3' em L. helveticus .

Figura 33 - Avaliação de anticorpos anti-PspA1' do tipo IgG induzidos por L. lactis

recombinantes

Figura 34 - Avaliação de anticorpos anti-PspA1' do tipo IgG induzidos por L. casei recombinantes

Figura 35 - Avaliação de anticorpos anti-PspA1' do tipo IgG induzidos por L. helveticus

recombinantes

Figura 36 - Avaliação de anticorpos anti-PspA1' do tipo IgG induzidos pelas bactérias

lácticas recombinantes

\section{Tabelas}

Tabela 1 - Quantificação de PspA produzida nas bactérias recombinantes 


\section{LISTA DE TAMPÕES}

Tampão de amostra para SDS-PAGE 10X - 1M Tris $\mathrm{HCl} \mathrm{pH}$ 6,8, 10\% SDS, 0,5\% azul de bromofenol, 50\% glicerol, 14,3M $\beta$-mercaptoetanol;

Tampão carbonato-bicarbonato - $50 \mathrm{mM} \mathrm{Na}_{2} \mathrm{CO}_{3}, 50 \mathrm{mM} \mathrm{NaHCO}_{3}$, ajustado para $\mathrm{pH} 9$,6;

Tampão citrato-fosfato $0,1 \mathrm{M}-0,1 \mathrm{M}$ citrato de sódio, $0,2 \mathrm{M}$ fosfato de sódio monobásico, ajustado para $\mathrm{pH} 5,0$;

Tampão de eletroporação para L. casei - 0,3M sacarose, $5 \mathrm{mM}$ fosfato de sódio pH7,4 e 1mM $\mathrm{MgCl}_{2}$;

Tampão de eletroporação para L. helveticus - $1 \mathrm{M}$ sacarose e $2,5 \mathrm{mM} \mathrm{CaCl}_{2}$;

Tampão de eletroporação para L. lactis - 0,5M sacarose e 10\% glicerol;

Tampão Ficoll - 0,02\% azul de bromofenol, 0,04\% xileno cianol e 5\% glicerol;

Tampão GTE - 50mM glicose, 25mM Tris pH8 e 10mM EDTA pH8;

Tampão de ligação de DNA - 80mM Tris- $\mathrm{HCl}$ pH7,6, $8 \mathrm{mM} \mathrm{MgCl} 2,1 \mathrm{mM}$ DTT, $1 \mathrm{mM}$ ATP e 5\% PEG;

Tampão PBS - 10mM tampão fosfato de sódio e 0,15M cloreto de sódio - pH7,2;

Tampão PBS-T - 10mM tampão fosfato de sódio, $0,15 \mathrm{M}$ cloreto de sódio - pH7,2 e 0,1\% Tween 20;

Tampão TAE 1X - 40mM Tris-Acetato pH 7,6 e 1mM EDTA;

Tampão Tris-glicina $1 \mathrm{X}-25 \mathrm{mM}$ Tris base, $250 \mathrm{mM}$ glicina e $0,1 \%$ SDS;

Tampão utilizado na lise mecânica - 100mM Tris-HCl pH8, com adição de coquetel de inibidores de proteases (Sigma). 


\section{SUMÁRIO}

1 INTRODUÇÃO ..................................................................................................... 01

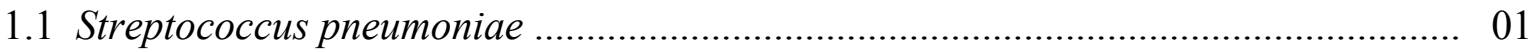

1.1.1 Fatores de virulência ........................................................................................ 03

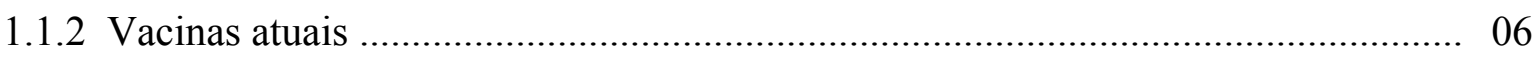

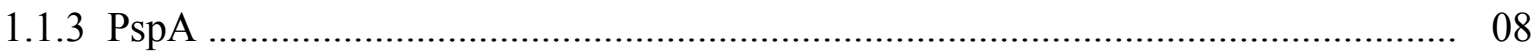

1.2 Lactobacillus ssp ……………………………………………………………... 13

1.2.1 Lactobacilos como probióticos .......................................................................... 14

1.2.2 Vacinas de mucosa ................................................................................ 16

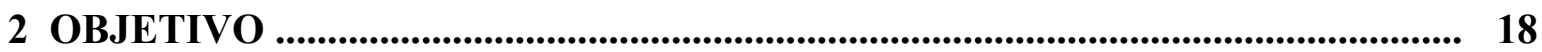

3 MATERIAIS E MÉTODOS ............................................................................. 19

3.1 Plasmídios, linhagens de bactérias e condições de crescimento ............................... 19

3.2 Amplificação dos fragmentos pspA1', pspA3', $a b 1$ e $a b 3$...................................... 19

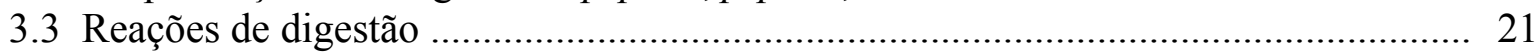

3.4 Reações de ligação ............................................................................................. 21

3.5 Preparação de Lactococcus lactis competente e transformação ................................. 23

3.6 Análise dos clones recombinantes de Lactococcus lactis por PCR ........................... 23

3.7 Preparação de DNA plasmidial em pequena escala ................................................... 24

3.8 Preparação de Lactobacillus casei competente e transformação ................................ 24

3.9 Preparação de Lactobacillus helveticus competente e transformação ......................... 24

3.10 Análise da expressão constitutiva das proteínas heterólogas em Lactococcus lactis, Lactobacillus casei e Lactobacillus helveticus, por Western-blot ............... 25

3.11 Análise da exposição das proteínas heterólogas nas bactérias lácticas íntegras ...... 26

3.12 Curva de crescimento das bactérias recombinantes .............................................. 27

3.13 Quantificação de PspA produzida pelas bactérias recombinantes ........................... 27

3.14 Imunização de camundongos ........................................................................... 28

3.15 Análise preliminar da produção de anticorpos anti-PspA' em camundongos após

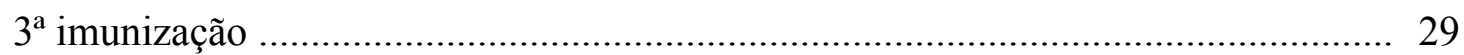

4 RESULTADOS E DISCUSSÕES ................................................................. 30

4.1 Amplificação dos fragmentos $p s p A 1$ ' e $p s p A 3^{\prime}$................................................... 30

4.2 Amplificação dos fragmentos $a b 1$ e $a b 3$............................................................... 31

4.3 Reações de digestão ......................................................................................... 32

4.4 Transformação de Lactococcus lactis, Lactobacillus casei e Lactobacillus

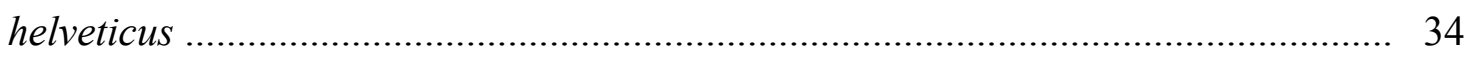

4.5 Análise dos clones recombinantes de Lactococcus lactis por PCR ......................... 35

4.6 Análise da expressão constitutiva das proteínas heterólogas em Lactococcus lactis,

Lactobacillus casei, e Lactobacillus helveticus por Western-blot ............................ 37

4.7 Análise da exposição das proteínas heterólogas nas bactérias lácticas íntegras ........ 44

4.8 Curva de crescimento das bactérias recombinantes ................................................ 45

4.9 Quantificação de PspA produzida pelas bactérias recombinantes ............................. 49

4.10 Análise preliminar da produção de anticorpos anti-PspA' em camundongos após

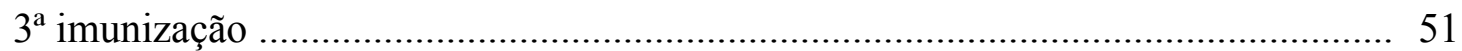

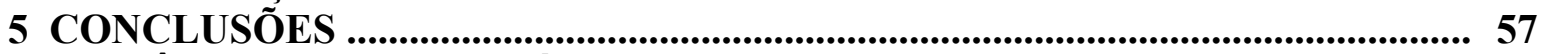

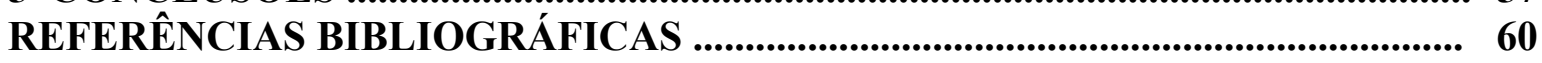

ANEXOS ............................................................................................................................ 71 


\section{INTRODUÇÃO}

\subsection{Streptococcus pneumoniae}

S. pneumoniae (pneumococo) caracteriza-se por ser um coco gram-positivo encapsulado, não produtor de catalase, anaeróbico facultativo, mas que cresce melhor em atmosfera rica em $\mathrm{CO}_{2}(5 \%)$ ou anaerobiose. Possui metabolismo fermentativo, que tem como produto final o ácido láctico. É auxotrófico para colina, e formador de colônias $\alpha$-hemolíticas em meio agar-sangue, e é sensível a optoquina (Teixeira e Trabulsi, 2004). Este patógeno humano causa uma variedade de doenças, incluindo pneumonia, meningite, septicemia, ou infecções locais como otite média aguda e sinusite. Comparando com as doenças invasivas, as doenças não invasivas são menos severas, porém são as mais freqüentes (World Health Organization - WHO, 1999). O pneumococo é a maior causa de morbidade e mortalidade no mundo, particularmente em crianças, idosos e pacientes imunocomprometidos, sendo que este último grupo tem 40 vezes mais chance de desenvolver algumas das doenças descritas acima (Bogaert et al., 2004a). Nos Estados Unidos e Canadá, há entre 15.000 e 30.000 casos anualmente de doenças pneumocócicas invasivas em idosos, sendo que um caso em cinco resulta em morte (Butler e Schuchar, 1999). Dados baseados na população com doenças invasivas sugerem uma incidência anual nos países desenvolvidos de 15 a 20 por 100.000 pessoas de todas as idades, e mais de 50 casos por 100.000 idosos acima de 65 anos (Fedson e Scott, 1999a). Em relação às crianças, pelo menos um milhão, menores de 5 anos, morrem de doenças pneumocócicas todos os anos, a maioria destas em países em desenvolvimento (WHO, 1999). O Brasil tem uma incidência de 10 casos de meningite pneumocócica a cada 100.000 crianças, acima de um ano de idade, sendo que $27,5 \%$ destes casos são fatais (Brandileone et al., 2003).

O pneumococo faz parte da flora microbiana normal da nasofaringe de humanos assintomáticos, sendo que para sua colonização é requerida a aderência no epitélio do trato respiratório. Esta aderência é obtida através dos carboidratos da superfície celular do epitélio não inflamado com proteínas associadas à parede celular do pneumococo. Além disso, as proteínas de superfície contribuem nas características hidrofóbicas e eletrostáticas da superfície do pneumococo, que podem facilitar a aderência nas células do hospedeiro, através de interações físico-químicas não-específicas (Bogaert et al., 2004b). Contudo diferentes razões podem levar o patógeno a desencadear a doença. Dentre estas, existem: 
- as condições ambientais como o tempo, condições atmosféricas e a poluição do ar (Kim et al., 1996);

- a competição entre bactérias do mesmo nicho, sendo que, esta dinâmica de populações varia com fatores sociais, como em multidões, em fumantes, ou de acordo com a idade;

- infecções virais ou outras doenças, no trato respiratório ou não, como por exemplo, infecções por HIV (Bogaert et al., 2004b).

- competição entre diferentes sorotipos de pneumococos, porém apenas evidenciada em modelo animal (Lipsitch et al., 2000).

Alguns autores propõem que a conversão da colonização assintomática para doença invasiva requer a liberação local de fatores inflamatórios, como interleucina 1 (IL-1) e fator de necrose tumoral, como visto na presença de infecção viral. Esta cascata inflamatória muda a quantidade e tipos de receptores nas células-alvo epiteliais e endoteliais. Proteínas pneumocócicas de parede celular mostram maior afinidade por estes receptores, e a ligação nestes receptores induz a internalização do pneumococo e promove a migração através do epitélio respiratório e endotélio vascular, resultando na invasão da bactéria (Bogaert et al., 2004b).

Com o advento do antibiótico, as doenças bacterianas têm sido vencidas, entretanto o rápido desenvolvimento e disseminação de mecanismos de resistência bacteriana estão tornando os antibióticos obsoletos. O aumento de cepas de pneumococo resistentes à importantes drogas, incluindo $\beta$-lactâmicos e macrolídios, tem sido observado em países desenvolvidos e em desenvolvimento. Mecanismos de resistência podem envolver a introdução de mutações em genes codificadores de proteínas ligadoras de penicilina, reduzindo então a afinidade por este antibiótico. Foi descrito que, entre cepas suscetíveis, estes genes diferem apenas $0,4 \%$, enquanto que as cepas resistentes diferem em 7 a $18 \%$ dos nucleotídeos das cepas suscetíveis, cerca de 27 a 86 aminoácidos (Laible et al., 1991).

Entretanto, um estudo nos Estados Unidos mostrou que as variações geográficas da proporção de resistência das cepas são explicadas pelas diferentes pressões seletivas regionais, mostrando também uma tendência do rápido aumento de cepas duplamente resistentes para penicilina e eritromicina (McCormicK et al., 2003). Outro estudo mostrou a associação entre a diminuição de susceptibilidade à penicilina e o alto uso de $\beta$-lactâmicos (Diekema et al., 2000). Porém, em animais, mostraram a eficiência de $\beta$-lactâmicos em infecções pneumocócicas causadas por cepas de diferentes níveis de susceptibilidade à 
penicilina, inclusive às de alta resistência (MIC $\leq 2 \mathrm{mg} / \mathrm{L}$ ), exceto para infecções do sistema nervoso central, em função da baixa penetração de $\beta$-lactâmicos (Pichardo et al., 2005).

Além disso, atualmente, existe um grande esforço no desenvolvimento de novas drogas para tratamento de infecções pneumocócicas, particularmente contra pneumococos multi-drogas resistentes (Hoffman-Roberts et al., 2005). Portanto, o surgimento de pneumococos resistentes a drogas, e as limitadas opções terapêuticas seguras para tratamento com sucesso de infecções causadas por este patógeno acentuam a necessidade de alternativas eficazes contra estas doenças.

\subsubsection{Fatores de virulência}

A importância global do $S$. pneumoniae justifica as pesquisas para solucionar questões pendentes sobre os pneumococos, principalmente sobre seus fatores de virulência. Os fatores de virulência do pneumococo mais importantes são: (1) a cápsula polissacarídica, que teve um papel importante na descoberta do "princípio de transformação", onde o DNA e a informação genética foram pela primeira vez conectados (Avery et al.,1944); e (2) várias proteínas associadas à parede celular, dentre elas a família das proteínas ligadoras de colina (CBPs), que são proteínas que têm em comum um domínio de ligação à colina e são alvos potenciais de novas terapias.

A cápsula de pneumococos é composta por unidades repetidas de oligossacarídeos expostos para fora da parede celular, que permanecem presas, possivelmente de forma covalente, à superfície das bactérias. Ela pode funcionar como adesina, e favorecer a camuflagem da bactéria contra a resposta imune do hospedeiro, como a fagocitose. Ela parece ser dispensável à viabilidade da célula, entretanto a cápsula dos pneumococos é absolutamente requerida para virulência, conforme demonstrado por Frederick Griffith em 1928 (apud Lopez e Garcia, 2004). Um estudo mostrou também a incapacidade de colonização em camundongos por certas cepas, quando estas apresentavam mutações no lócus da cápsula, ou seja, na ausência de cápsula. Entretanto, com $20 \%$ da cápsula parental, a colonização foi eficiente, sugerindo que a presença de uma quantidade mínima de cápsula é essencial para colonização. A virulência intraperitoneal não foi diminuída na ausência da cápsula, diferente da intravenosa e intranasal que foi diminuída, sugerindo um papel adicional da cápsula na patogênese do S. pneumoniae (Magee e Yother, 2001). Por outro lado, cepas na fase transparente, ou seja, com menor expressão da cápsula polissacarídica e maior expressão 
de certas proteínas e carboidratos contidos na parede celular, mostraram ter melhor aderência nas células epiteliais do que cepas na fase opaca, ou seja, com maior expressão da cápsula (Bogaert et al., 2004b).

A cápsula também apresenta uma composição complexa, é altamente variável na estrutura química, e freqüentemente contém alguns componentes não sacarídicos, explicando a alta variabilidade antigênica destes polímeros (Lopez e Garcia, 2004). Com base nesta alta variabilidade, foram tipados, até 1995, 90 sorotipos diferentes (Henrichsen, 1995). A epidemiologia destes sorotipos varia de acordo com a idade, a localidade geográfica, e fatores ambientais como doenças, hospitalização, etc. (Hausdorff et al., 2005). Existem sorogrupos que diminuem a colonização da nasofaringe com o passar da vida, como o sorogrupo 1, enquanto que outros aumentam, como o 3 e o 8; os sorogrupos 7 e 23 são os mais comuns na terceira década de vida (Scott et al., 1996). No Brasil, os sorotipos mais prevalentes $(74,4 \%)$ estão associados com as doenças invasivas, sendo que estes variam com a região do país, com a idade e com a doença do paciente amostrado. Os sorotipos mais prevalentes no Brasil são 14, 1, 6B, 5, 18C, 6A, 3, 23F, 19F, 9V, 4, 19A, 10A (Brandileone et al., 2003), variando a ordem de prevalência conforme a região (Sessegolo et al., 1994; Mantese et al., 2003).

Outro fator de virulência, abaixo da cápsula polissacarídica, é a parede celular que consiste de peptideoglicano, polissacarídeos associados a ele (ácido teicóico), polissacarídeos associados à membrana (ácido lipoteicóico), e várias proteínas associadas. A parede celular é responsável pela intensa reação inflamatória que acompanha as infecções pneumocócicas, pois ela estimula o fluxo de células inflamatórias, ativa a cascata do complemento, e a produção de citocinas (Bogaert et al., 2004a). Os polissacarídeos, presentes na parede celular, possuem sítios de fosfocolina, onde se ligam as CBPs. A variabilidade na composição, expressão, ou exposição das proteínas associadas à superfície pode explicar as diferenças na capacidade de colonização e invasão entre as cepas. Esforços para determinar o papel de várias proteínas pneumocócicas, na colonização e na patogenicidade como uma oportunidade futura de controle da infecção, estão atualmente sendo feitos. Além disso, estas proteínas estão sendo estudadas como potenciais novos candidatos vacinais, e algumas estão resumidamente descritas a seguir:

- 4 CWHs (hidrolase de parede celular) foram identificadas no genoma do pneumococo, sendo que estas também pertencem ao conjunto de mais de 15 CBPs. As CWHs estudadas são: a LytA (a mais importante autolisina desta bactéria) cujo papel é de liberar toxinas intracelulares, como a Pneumolisina (Ply) e também o DNA; LytB que parece ser a única murino-hidrolase com função na separação celular do pneumococo, quando este está se 
dividindo, sendo que foi relatado que anticorpos contra esta proteína protegeram significativamente camundongos contra desafio letal com algumas cepas; LytC (uma lisozima) que também pode contribuir na liberação do DNA no meio ambiente, o que facilita a troca de DNA entre cepas; e por último, PcE (também conhecida como $\mathrm{CbpE}$ ) pode ter um papel fundamental na regulação do número de resíduos de colina presentes nos ácidos teicóicos (Lopez e Garcia, 2004);

- IgA1 protease, que além da clivagem de IgA1, aumenta a aderência do pneumococo em células epiteliais na presença de IgA1 humana anti-cápsula. Este efeito ocorreu somente quando houve a clivagem de IgA por esta protease, que resultou em uma mudança de carga na superfície e um aumento da proximidade física da colina da parede celular de pneumococo aos receptores do epitélio. Isto sugere que este patógeno se apropria de componentes antígeno-específico da resposta imune adquirida para promover colonização (Weiser et al., 2003);

- NanA (Neuraminidase), que diminui a viscosidade do muco e expõe receptores das células epiteliais, clivando também glicolipídios, glicoproteínas e oligossacarídios (Bogaert et al., 2004b);

- PsaA (adesina A de superfície de pneumococo), uma lipoproteína ligadora de metal, que sabidamente está envolvida no transporte de manganês para o interior do pneumococo, e na colonização assintomática. Os primeiros estudos de imunização com esta proteína mostraram alta proteção contra colonização e limitada ou modesta proteção contra doenças invasivas (Bogaert et al., 2004b; Briles et al., 2000a);

- PspC (proteína C de superfície de pneumococo - também conhecida como CbpA, Hic, SpsA) interage com a via do complemento, através de ligação com o componente $\mathrm{C} 3$ e fator H. Tem sido demonstrado também que ela age como adesina e tem um papel importante na colonização nasofaringeal e na ligação das células do epitélio ativado por citocinas (Balachandran et al., 2002). Cepas mutadas no gene $p s p C$ foram atenuadas na capacidade de colonizar, e foram incapazes de infectar e se multiplicar no pulmão, sendo que na bacteremia estas cepas comportaram-se como as cepas selvagens. Foi demonstrado também que o gene $p s p C$ é ativamente transcrito in vivo, quando a bactéria está crescendo na cavidade nasal e nos pulmões (Balachandran et al., 2002). Estudos de imunização também foram feitos, mostrando alta proteção contra ensaios de desafio intraperitoneal (Ogunniyi et al., 2001) e intranasal (Balachandran et al., 2002);

- Pneumolisina (Ply) tem propriedades citotóxicas mediadas por diferentes domínios da toxina, que inibem resposta imune específica e não-específica, bem como estimulam a 
liberação de citocinas pelas células do hospedeiro. Ply também ativa o sistema complemento, que é resultado da ligação com a região $\mathrm{Fc}$ da $\mathrm{IgG}$, o que contribui para inflamação e depleção de opsonização (Ogunniyi et al., 2001). O toxóide genético PdB foi capaz de induzir altos índices de anticorpos em experimentos de imunização de camundongos, entretanto, estes índices foram menores quando comparados com outros antígenos protéicos pneumocócicos. Além disso, o tempo médio de sobrevivência destes camundongos após o desafio foi maior nos que receberam PdB combinado com PspA (Ogunniyi et al., 2000; Briles DE et al., 2000a) ou combinado com PspC (Ogunniyi et al., 2001), quando comparados com os que receberam $\mathrm{PdB}$ sozinho. Isto sugere, em teoria, uma proteção melhor contra colonização e infecção do pneumococo após imunização com proteínas que possuem papéis distintos na virulência da bactéria (Ogunniyi et al., 2000);

- PspA (proteína A de superfície de pneumococo) é o antígeno escolhido para ser utilizado neste trabalho, que será descrito mais adiante.

\subsubsection{Vacinas atuais}

As vacinas atualmente comerciais são produzidas a partir da purificação dos polissacarídios das cápsulas dos pneumococos. A primeira a ser produzida contém os polissacarídios das cápsulas de 23 sorotipos diferentes, que teoricamente cobrem 85 a 90\% das cepas circulantes nos Estados Unidos (Centers for Disease Control and Prevention - CDC, 1997). Ela é eficaz em adultos imunologicamente competentes (Fedson, 1999b), mas nos grupos que apresentam maior risco como crianças, idosos e imunocomprometidos, sua eficácia é menor.

Diferentes níveis de anticorpos foram obtidos em crianças após a administração da vacina 23-valente, de acordo com o sorotipo, porém os índices diminuíram rapidamente após ambas as $1^{\mathrm{a}}$ e $2^{\mathrm{a}}$ doses (Koskela et al., 1986). Em imunocomprometidos, um estudo na Dinamarca mostrou um significante aumento dos níveis de anticorpos em $67 \%$ dos pacientes testados, após um mês de imunização com esta vacina, porém 12 meses depois os títulos de anticorpos específicos não foram significativamente diferentes dos pré-imunizados (Nielsen et al., 1998). Recentemente na África, além de mostrarem sua ineficácia em adultos infectados por HIV-1, pois significativamente mais casos de pneumonia foram vistos em pacientes que receberam a vacina do que no grupo controle, também constataram efeitos colaterais deletérios (French et al., 2000). 
Em idosos, a vacina 23-valente é estimada ser 50-80\% efetiva, porém a indução de proteção declina 3 a 5 anos depois, com níveis de anticorpos similares aos pré-imunes, sugerindo uma revacinação antes de 3 anos (Fedson, 1999b; Sankilampi et al., 1997). Dados na literatura mostraram que os idosos já possuem níveis detectáveis de anticorpos antes da vacinação, portanto presume-se que estes foram obtidos durante a vida, como resultado de prévia colonização ou infecção por pneumococos. Mostraram também, que a vacina foi capaz de induzir anticorpos para os 23 sorotipos no grupo de estudo, mas quando analisados individualmente, os níveis de anticorpos contra todos os 23 sorotipos dobraram apenas em $3,7 \%$ dos idosos (Rubins et al., 1999).

Apesar de no Brasil a vacina 23-valente proporcionar uma cobertura aproximada de $82,6 \%$ dos sorotipos (Mantese et al., 2003), o problema da resposta humoral fraca, de curta duração e sem memória no grupo de risco torna-a pouco eficiente para seu uso no sistema público de saúde, embora ela esteja em uso desde 1999 para idosos.

Como polissacarídios não requerem células $\mathrm{T}$ para induzir resposta imune, o que implica na ausência de células B de memória, e portanto um limitado período de proteção, a tecnologia de vacinas conjugadas, onde antígenos carboidratos são ligados quimicamente à um carreador protéico, tem auxiliado a superar estas limitações. A vacina conjugada atualmente utilizada, desenvolvida contra o pneumococo, é composta por polissacarídios de 7 sorotipos diferentes conjugados com toxóide diftérico. Este é uma variante inerte mas imunogênica da toxina diftérica, que também é usado como molécula carreadora na vacina conjugada contra Haemophilus influenza tipo b.

Esta vacina conjugada heptavalente proporciona uma cobertura de $85 \%$ para os Estados Unidos, 60-70\% para Europa e cerca de 55\% para Ásia, contra as cepas invasivas, com uma eficácia de $97,4 \%$ contra as doenças invasivas causadas pelos sorotipos da vacina (Bogaert et al., 2004a). Além disso, foi considerado que a diminuição de carreadores nasofaringiais pode conduzir à redução da disseminação dos sorotipos mais freqüentemente associados a doenças e resistência a antibióticos (Bogaert et al., 2004a). No Brasil, a cobertura da vacina heptavalente é estimada em 58,2\%, entre crianças de 7 meses a 5 anos, para as doenças pneumocócicas invasivas (Brandileone et al., 2003). Portanto, a substituição de alguns sorotipos presentes na vacina, por outros também prevalentes no Brasil, é requerida para aumentar sua cobertura.

Foi demonstrado que a vacina 7-valente é imunogênica em crianças. Ela foi capaz de reduzir as doenças pneumocócicas invasivas em $87 \%$ das crianças menores de um ano, 58\% para menores de 2 anos, e em 62 \% para menores de 5 anos. Entretanto a incidência de otite 
média aguda não foi reduzida significativamente, provavelmente porque não foi causada pelos sorotipos presentes na vacina, já que a incidência destes diminuiu (Pai et al., 2002). O CDC avaliou, nos Estados Unidos, um declínio substancial anual das doenças pneumocócicas invasivas em crianças, no período de 2001 a 2003, referente às cepas presentes na vacina. Foi detectado também, um aumento nas doenças causadas por sorotipos de pneumococos não inclusos na vacina, mas não significativo quando comparado ao declínio das doenças causadas por sorotipos presentes na vacina (CDC, 2005). Em crianças infectadas por HIV, a vacina mostrou ser segura e imunogência (Pai et al., 2002; Nachmen et al., 2003).

Alguns grupos sugerem que a interferência no balanço existente entre hospedeiro e patógeno, causada pela vacinação, pode induzir a substituição de cepas pneumocócicas (Bogaert et al., 2004a). Embora a vacina conjugada seja altamente protetora contra doenças pneumocócicas, ela falha na limitada cobertura dos sorotipos, conseqüentemente, o risco da indução de doenças causadas por cepas substituídas é potencialmente real. Além disso, a vacina tem alto custo, e deve ser administrada em 4 doses por criança, aos 2, 4, 6, e 12 a 15 meses (American Academy of Pediatrics, 2000), limitando a implementação na maioria dos países subdesenvolvidos.

\subsubsection{PspA}

PspA é uma proteína com 67 a $99 \mathrm{kDa}$, localizada em todos os pneumococos descobertos até o momento. É uma CBP, portanto está ligada aos resíduos de colina dos ácidos teicóico e lipoteicóico da parede celular de forma não covalente (Fig 1). Ela possui 5 diferentes domínios: um peptídeo sinal; uma região N-terminal exposta na superfície celular, em forma de $\alpha$-hélice altamente carregada, com uma forte periodicidade de 7 aminoácidos, típica de proteínas “coiled-coill” (regiões A e B); uma região rica em prolina (região C); um domínio de ligação à colina altamente conservado com 10 repetições de 20 aminoácidos; e uma região C-terminal com 17 aminoácidos hidrofóbicos (vide figura 2) (Jedrzejas, 2001). Como ilustrado na figura 1, estudos estruturais mostraram que PspA tem carga altamente polarizada: a região eletropositiva resulta na estabilização da carga negativa da cápsula, e a região eletronegativa da molécula provavelmente previne a ligação de $\mathrm{C} 3$ do sistema complemento (Jedrzejas, 2001). 


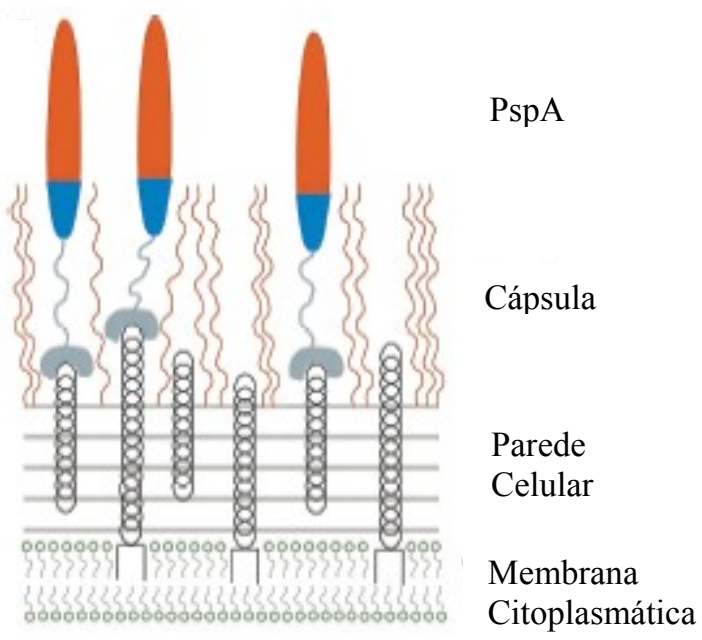

Fig. 1 - Esquema do arranjo das moléculas de PspA na superfície de Streptococcus pneumoniae: As interações de PspA na superfície com os ácidos teicóicos $(\infty \infty \infty)$ e com a cápsula, e a exposição da região altamente eletronegativa da porção N-terminal para fora da bactéria. As cores codificam o potencial eletrostático da porção N-terminal: azul é eletropositivo; vermelho é eletronegativo (Extraído de Jedrzejas, 2001).

Foi sugerido que PspA aumenta a virulência do pneumococo através da inibição da ativação do complemento, pois inibe a deposição de $\mathrm{C} 3 b$ e/ou redução do processamento da cadeia $\alpha$ de C3b. Foi observada a depleção de C3 no soro de camundongos desafiados com pneumococo PspA; , o que não foi observado com o soro dos camundongos desafiados com a cepa selvagem, ou seja, houve o consumo de C3 na ausência de PspA. Camundongos C3- ou Fator B- deficientes, tiveram bacteremia para pneumococo PspA', tão intensa quanto para o pneumococo selvagem. Portanto, nestas duas condições na ausência de C3, a bactéria sem PspA também causou a doença. Porém, em camundongos C5-deficientes não houve virulência para cepa PspA', assim como foi visto nos camundongos selvagens. Ou seja, em ambos os camundongos, houve a deposição de C3, devido a ausência de PspA. Outra observação foi in vitro, que mais moléculas de $\mathrm{C} 3 \mathrm{~b}$ foram depositadas no pneumococo PspA opsonizado, do que na cepa selvagem (Tu et al., 1999). Em contraste, estudos mais recentes de citometria de fluxo mostraram que, na ausência de FB, a intensidade de deposição de C3 na bactéria $\operatorname{PspA}^{-}$é reduzida, mas não é eliminada. Isto sugere que, a via alternativa é importante para a amplificação da ativação do complemento e deposição na superfície do pneumococo, mas a via clássica é absolutamente requerida. Foi demonstrado também que PspA inibiu a deposição de C3, mesmo na presença de anticorpos anti-cápsula, que iniciam a via clássica do complemento. Por outro lado, a deposição foi maior na presença de anticorpos anti-PspA (Ren et al., 2004).

Outra importante atividade de PspA é de ligação à lactoferrina humana, que é uma glicoproteína monomérica ligadora de ferro predominante nas secreções de mucosa, onde o 
nível de ferro livre é muito baixo, não suficiente para o crescimento bacteriano. Secretada por células inflamatórias na fase aguda, ela pode funcionar como bactericida para muitos patógenos. Foi mostrada a capacidade de PspA purificado de se ligar a lactoferrina, e de inibir competitivamente a ligação desta proteína no pneumococo. Análise por Western-blot indicou que o domínio de ligação a lactoferrina localiza-se na região $\mathrm{N}$-terminal, região que não tem homologia com outras proteínas pneumocócicas. Outras proteínas ligadoras de colina (autolisina e PspC), que possuem homologia com PspA em outras regiões, foram testadas e não foram capazes de ligar a lactoferrina. Portanto, sugere-se que a interação de PspA com lactoferrina humana no pneumococo seja para superar a limitação de ferro na mucosa, podendo representar um mecanismo potencial de virulência (Hammerschmidt et al., 1999).

Com base no seqüenciamento dos alelos $p s p A$ de 24 cepas de pneumococos isolados, a porção N-terminal da proteína PspA foi dividida em três janelas: A, B e C (fig 2). As regiões mais conservadas de todos os genes $p s p A$ estão na porção 5' do gene (que codifica o início da região N-terminal) e na região 3' do gene (que codifica o domínio de ligação à colina). A região B foi escolhida para dividir os PspAs em 6 clados, que podem ser classificados em três famílias. Estudos de mapeamento indicaram que é nesta região de 100 aminoácidos da $\alpha$ hélice, adjacente a região rica em prolina, que residem os principais epítopos de proteção cruzada: Família 1 (clados 1 e 2), Família 2 (clados 3, 4 e 5), Família 3 (clado 6) (Hollingshead et al., 2000). As famílias 1 e 2 representam cada uma aproximadamente 50\% dos pneumococos, e a família 3 representa menos de 1\% (Briles et al.,2000a). Por exemplo, no Brasil, foi demonstrado que 50,5\% das cepas apresentaram PspA da família 1, 43,2\% PspA da família 2, e 6,2\% não foram tipadas. Entretanto, das cepas resistentes à penicilina, 83,8\% tinham PspA da família 2, enquanto que da família 1 eram apenas 10,3\% (Brandileone et al., 2004).

A média da distância interclado é cerca de $28 \%$ quando os genes comparados são da mesma família, e normalmente excedem a 50\% quando os genes são de famílias diferentes de PspA. Entretanto, PspA é notavelmente imunogênico e anticorpos anti-PspA apresentam reação cruzada. Estudos de proteção cruzada em camundongos mostraram que PspAs do clado 1 ao 4 foram capazes de induzir anticorpos protetores contra pneumococos que possuem PspA diferente em mais de 50\% dos aminoácidos da porção $\alpha$-hélice (Hollingshead et al., 2000). Por isso, os antígenos utilizados neste trabalho constituem-se de fragmentos da região N-terminal de PspA1 (clado 1, família 1) e PspA3 (clado 3, família 2). Sendo denominados PspA1' e PspA3' (para os que compreendem as janelas ABC) e AB1 e AB3 (para os que compreendem as janelas $\mathrm{AB}$ ), conforme esquema da figura 2. Assim, uma vacina composta 
por PspAs da família 1 e da família 2 pode, teoricamente, proteger contra a grande maioria dos sorotipos de pneumococos, já que estas 2 famílias abrangem 99\% dos sorotipos existentes.

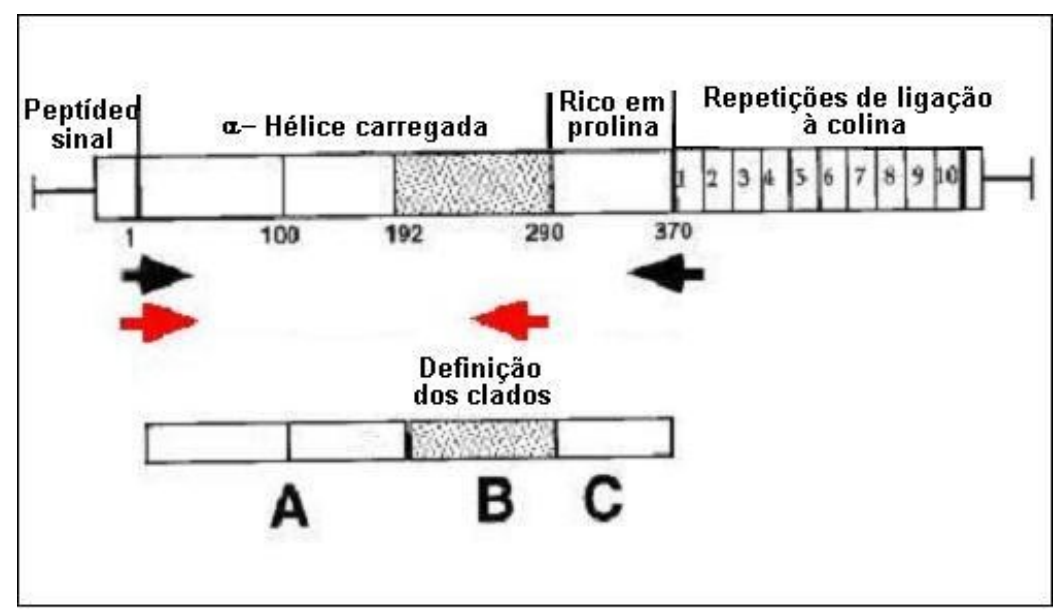

Fig. 2 - Esquema das regiões da proteína PspA, mostrando as janelas das seqüências amplificadas (AB e $\mathrm{ABC}$ ). Os números fora dos quadros indicam os resíduos de aminoácidos. As setas indicam os oligonucleotídeos usados para PCR. (Figura adaptada de Hollingshead ., 2000).

Indução de anticorpos anti-PspA e proteção em ensaios de desafio foram mostrados através de diferentes vias de imunização (subcutânea, intraperitoneal, intranasal, oral) com diferentes porções de PspA (recombinante ou obtido após purificação de pneumococo), junto com diferentes adjuvantes (Briles et al., 2001; Yamamoto et al.,1997; Areas et al.,2005). Estes anticorpos foram melhores protetores contra as doenças invasivas (bacteremia/septicemia ou infecção pulmonar) e pouco protetores contra colonização da nasofaringe. Entretanto, quando combinado com outros antígenos pneumocócicos, como o PdB ou PsaA, a proteção foi melhorada para as doenças invasivas e para colonização (Briles et al., 2000a). Contudo, em alguns trabalhos, a indução de anticorpos foi melhor obtida para os do tipo IgG, e apenas baixos níveis de IgA foram obtidos (Briles et al., 2000b e 2001). Vacinas de DNA, com vetores portando diferentes fragmentos do gene $p s p A$, também induziram resposta imune humoral, e reatividade cruzada entre $p s p A s$ pertencentes à mesma família. Entretanto, a reatividade de anticorpos não foi refletida na proteção cruzada, somente foram protegidos os animais desafiados com cepa de pneumococo contendo PspA pertencente ao mesmo clado (Miyaji et al., 2002a).

Atualmente, foi realizada a fase I dos testes em humanos com PspA recombinante pertencente ao clado 2, que mostrou ser altamente imunogênico e dose dependente. Após duas doses de imunização intramuscular acompanhado do adjuvante alumínio $\left(\mathrm{Al}(\mathrm{OH})_{3}\right)$, com intervalo de 30 dias, observou-se, após 60 dias da primeira dose, um aumento de 6,5 vezes 
dos níveis de anticorpos para os indivíduos imunizados com $5 \mu \mathrm{g}$ de proteína, um aumento de 9,7 vezes naqueles imunizados com $25 \mu \mathrm{g}$ de proteína, e 24 vezes naqueles imunizados com $125 \mu \mathrm{g}$. Estes anticorpos foram capazes de se ligar a diferentes cepas de pneumococos, expressando diferentes tipos de PspA e portando diferentes tipos de cápsula (Nabors et al., 2000). Estes anticorpos também foram capazes de proteger camundongos, após imunização passiva, contra infecção fatal com cepas portando o mesmo tipo de cápsula, mas com PspA da família 1 ou 2, ou seja, houve proteção cruzada entre famílias. No soro de humanos, foram produzidos 100 vezes mais anticorpos por mililitro requeridos para esta proteção em camundongos (1,3 $\mu \mathrm{g} /$ dose) (Briles et al., 2000c).

Portanto, devido à boa caracterização deste antígeno, foram escolhidos os fragmentos PspA1', PspA3', AB1 e AB3 para expressão em bactérias lácticas, o que permitiu a análise da eficácia deste sistema para a indução da produção de anticorpos anti-PspA em camundongos, após os ensaios de imunização. 


\subsection{Lactobacillus ssp}

Lactobacilos são bactérias gram-positivas, anaeróbicas facultativas (microaerofílicas), sem motilidade, sem formação de esporo, catalase negativas, não possuem citocromo, e como outras bactérias ácido-lácticas (LAB) são ácido-tolerantes, com melhor crescimento em torno de $\mathrm{pH} 5$ e 6 . Possuem um estrito metabolismo fermentativo de carboidrato, com ácido láctico como principal produto metabólico final. A capacidade de crescer em fontes específicas de energia e as vias de fermentação podem variar entre as espécies de lactobacilos (Somkuti, 2000). O gênero lactobacilos compreende mais de 50 espécies amplamente diferenciadas nas propriedades bioquímicas, imunológicas e genéticas. Esta grande variação é refletida na grande diferença da quantidade de G-C em seus DNAs, por exemplo, em Lactobacillus helveticus (L. helveticus) é de 36\% e em Lactobacillus fermentum (L. fermentum) é de mais de $50 \%$. O controle de transcrição e tradução também pode diferir muito de uma espécie para outra, implicando que o conhecimento obtido para um organismo pode não ser transferido para outro. Além disso, muitas diferenças nas propriedades e na estrutura da superfície têm sido vistas entre as espécies de lactobacilos, o que contribui em diferenças na capacidade de sobreviver e aderir na mucosa de diferentes hospedeiros (Pouwels et al., 1998). Por isso, apenas algumas cepas de lactobacilos são encontradas como comensais naturais do trato gastrintestinal, cavidade oral e trato urogenital, o que difere também entre animais e humanos.

Durante séculos, as LABs têm sido amplamente utilizadas no processamento e na preservação de gêneros alimentícios, como lacticínios (queijo, iogurte), embutidos, dentre outros (Pouwels et al., 1998). Certas espécies de LABs têm características probióticas, ou seja, são microorganismos, que após ingestão de certa quantidade, exercem efeitos benéficos para a saúde do hospedeiro, além de formar uma flora microbiana intestinal balanceada.

Os lactobacilos podem conferir proteção ao seu hospedeiro, pelo aumento da resistência contra colonização de patógenos no intestino, através de uma barreira de mucosa reforçada e restauração da flora normal após diarréia, além de poderem competir com patógenos por sítios de ligação e substratos disponíveis. Deste modo, a efetiva colonização e adesão em superfície de mucosa humana são freqüentemente consideradas importantes para os efeitos probióticos dos lactobacilos (Meurman, 2005). Além disso, podem produzir diferentes componentes antimicrobianos como ácidos orgânicos, peróxido de hidrogênio, peróxido de carbono, diacetil, bacteriocinas e inibidores de adesão (Meurman, 2005). 
Outras características fazem dos lactobacilos bons candidatos vacinais, como por exemplo:

- resistência a ácido e sais biliares, no caso da administração por via oral, pois necessita passar pelo trato gastrintestinal superior para posterior adesão no intestino. Entretanto, esta característica varia entre as espécies de lactobacilos (Pereira e Gibson, 2002). Além disso, a resistência a microbicidas vaginais pode ser requerida no caso da ação desejada ser no trato urogenital;

- persistência no local de atuação, pois sugere-se que quanto maior o tempo de permanência, maior é a estimulação do sistema imune. Utilizando duas espécies de lactobacilos que apresentaram propriedades similares in vitro, mas diferenças quanto à capacidade de colonização in vivo, Ibnou-Zekri e colaboradores (2003) demonstraram maior indução de anticorpos, do tipo IgG e IgA, pela espécie capaz de permanecer em maior quantidade e por maior tempo no intestino;

- ser seguro (GRAS-status - bactérias geralmente consideradas seguras), ou seja, não invasivo, não carcinogênico, e não patogênico (Reid, 1999).

Outra interessante característica dos lactobacilos é o seu potencial adjuvante, ou seja, seu potencial de estimular o sistema imune. Os lactobacilos podem interagir com células $\mathrm{M}$ das placas de Peyer ou células do epitélio intestinal e com isso aumentar células $\mathrm{B} \operatorname{IgA}^{+}$e $\mathrm{T}$ $\mathrm{CD}^{+}$locais, além de aumentar a migração destas células para outras mucosas como o trato respiratório. Entretanto, este efeito é dependente da espécie de LAB e da dose fornecida. Foi demonstrado que Lactobacillus casei (L. casei) e Lactobacillus plantarum (L. plantarum) foram mais eficientes em estimular as células imunes das placas de Peyer no intestino, do que Lactococcus lactis (L. lactis), e outras bactérias lácticas (Perdigon et al., 1999). Outras comparações entre diferentes cepas quanto à capacidade de estimular o sistema imune, e o padrão de citocinas estimuladas, mostraram que L. reuteri e L. brevis foram os melhores indutores, pois eles estimularam respostas imunes inata, celular e humoral (Maassen et al., 2000).

\subsubsection{Lactobacilos como probióticos}

Com base em suas propriedades probióticas, inúmeros estudos sobre o potencial bioterapêutico e profilático têm sido realizados, com alguns exemplos descritos a seguir: 
- diferentes espécies de lactobacilos foram capazes de prolongar a vida de camundongos imunodeficientes (atímicos) colonizados por Candida albicans no trato gastrintestinal. Além de diminuir a incidência de candidíase sistêmica, quando comparado com o grupo controle na presença apenas de Candida albicans. Nenhuma das espécies foi capaz de prevenir completamente a candidíase, mas foram capazes de modular resposta imune celular e humoral contra ela. Esta resposta foi mais eficiente em camundongos normais, inoculados com $L$. casei. Além de demonstrar que lactobacilos não são patogênicos em camundongos imunodeficientes, este trabalho demonstrou o potencial bioterapêutico destas bactérias para profilaxia e terapia contra esta doença fúngica (Wagner et al., 1997);

- a mistura de duas espécies de lactobacilos (L. reuteri e L. rhamnosus), previamente caracterizadas quanto o potencial probiótico in vitro e em humanos saudáveis, foi capaz de diminuir a diarréia aguda em crianças causada por rotavírus. No final do tratamento, o antígeno de rotavírus foi encontrado em $12 \%$ dos pacientes que ingeriram os lactobacilos contra $46 \%$ dos pacientes que receberam placebo (Rosenfeldt et al., 2002);

- redução de Helicobacter pylori (H. pylori), agente causal de gastrite e úlcera, além da redução dos efeitos colaterais da terapia de antibiótico (Meurman, 2005);

- redução da ocorrência de colonização nasal com patógenos potenciais em humanos, incluindo Staphylococcus aureus e S. pneumoniae, após administração oral de LABs, incluindo L. rhamnosus e L. acidophilus, demonstrando também a ligação entre o tecido linfóide do intestino e do trato respiratório superior (Gluck e Gebbers, 2003). Outro exemplo foi a administração nasal de 4 doses com $10^{7}$ CFUs (unidades formadoras de colônia) de $L$. fermentum em camundongos que promoveu uma grande redução de $S$. pneumoniae no trato respiratório, após desafio com $10^{9} \mathrm{CFUs}$. Isto ocorreu talvez devido à produção de antagonistas contra o pneumococo, que podem ter diminuído sua capacidade de aderir. Além disso, L. fermentum foi capaz de diminuir a inflamação do tecido causada por esta bactéria, e demonstrou alta resposta imune não específica contra o pneumococo, através do alto número de macrófagos ativados e alto número de linfócitos (Gutierrez et al., 2001);

- ensaios em humanos mostraram a redução da incidência de infecções no trato urogenital e restauração da microflora vaginal após inoculação local de uma suspensão de L. rhamnosus ou L. fermentum, além da ausência de infecção por levedura que freqüentemente ocorre como efeito colateral de antibióticos (Reid, 1999);

- redução dos problemas associados com intolerância ou má digestão de lactose, provavelmente devido auxílio da lactase microbiana, porém esta propriedade varia entre os gêneros de LAB (Chandran, 1999; deVrese et al., 2001); 
- redução da resposta inflamatória de colite induzida em ratos e recuperação de tecido inflamado após administração de L. fermentum (Peran et al., 2005), e melhora na inflamação crônica abdominal em camundongos, associados com diminuição de citocinas proinflamatórias como IL-6 e IFN- $\gamma$, induzidos por L. casei (Matsumoto et al., 2005).

\subsubsection{Vacinas de mucosa}

As mucosas têm atualmente emergido como promissoras rotas de imunização, devido às muitas vantagens que apresentam. Uma delas é que este tipo de imunização pode induzir resposta imune local e sistêmica, além de indução de resposta imune em tecidos de mucosa distantes. Outra vantagem é que, devido à superfície de mucosa ser a principal via de entrada de muitos patógenos, o desenvolvimento de vacinas protetoras de mucosa seria um eficiente método de prevenir a infecção inicial e a replicação do patógeno, e portanto muitos tipos de doenças infecciosas. Além disso, elas podem ser administradas via nasal ou oral, e portanto não necessitam de profissionais altamente qualificados para sua aplicação. Também não necessitam de agulhas, o que diminui o risco de contaminação, além de ter seu custo diminuído, quando comparado com vacinas injetáveis. Com base nisto, o desenvolvimento de bactérias vivas carreando antígenos de interesse tem sido amplamente estudado, a fim de se obter uma vacina que induza eficientemente resposta imune local. Muitos grupos estudam patógenos vivos atenuados como carreadores, porém um dos problemas deste sistema é a necessidade de reduzir a patogenicidade sem interferir em sua imunogenicidade, além da preocupação quanto à segurança deste sistema para uso em humanos. Por isso, lactobacilos, com inúmeras vantagens já descritas neste trabalho, além da vantagem de sua produção em larga escala ser fácil e barata, tornam-se atrativos candidatos como veículos vacinais.

Desta forma, lactobacilos recombinantes têm sido construídos, para análise do seu potencial de indução de resposta imune contra diferentes antígenos. $\mathrm{O}$ antígeno mais estudado em LABs é o fragmento $C$ da toxina tetânica (TTFC), que mostrou ser altamente imunogênico em camundongos, após diferentes vias de administração (nasal, oral, e subcutânea), veiculado por diferentes bactérias como L. plantarum, L. lactis e L. casei (resumido por Seegers, 2002). Estas bactérias foram capazes de induzir altos títulos de anticorpos protetores do tipo IgG e IgA. Como outros exemplos, temos: 
- L. plantarum expressando UreB, uma subunidade da urease de H. pylori, que após imunização oral, foi capaz de induzir altos títulos de anticorpos do tipo $\operatorname{IgA}$ e $\operatorname{IgG}$ em camundongos (Corthesy, et al., 2005);

- L. casei secretando a glicoproteína $\mathrm{S}$ de coronavírus de gastroenterite, um vírus enteropatogênico de porcos, que após imunização oral de camundongos, induziu altos títulos de anticorpos quando comparado com o controle negativo (Ho et al., 2005);

- L. johnsonii recombinante, expressando na parede celular subunidades que mimetizam epítopos de IgE humana, após imunização subcutânea e nasal em camundongos, foi capaz de induzir IgG sistêmica contra IgE humana. Isto representa um novo modelo de vacinação para indução de resposta anti-IgE, como uma nova estratégia de prevenir doenças alérgicas (Scheppler et al., 2005);

- L. lactis secretando IL-10, uma IL com resultados promissores no tratamento de doenças inflamatórias do abdômen, que após administração intragástrica, reduziu em $50 \%$ colite induzida em camundongos, além de prevenir a doença em camundongos "knock-out" para IL10 (Steidler et al., 2000);

- L. casei, L. helveticus e L. plantarum recombinantes, todos expressando PsaA de $S$. pneumoniae, foram capazes de induzir a produção de anticorpos anti-PsaA em camundongos, além de diminuir a colonização deste patógeno em ensaios de desafio (Oliveira et al., 2006 in press - vide Anexos). 


\section{OBJETIVOS}

Avaliação de diferentes bactérias lácticas quanto à capacidade de expressão, de forma constitutiva, de diferentes fragmentos de PspA, tanto na porção intracelular como ancorado à parede celular.

Avaliação das bactérias recombinantes produzidas na indução de anticorpos antiPspA, após imunização nasal de camundongos.

\section{Etapas:}

- Amplificação de diferentes fragmentos da porção N-terminal de $p s p A$;

- Clonagem nos vetores de expressão constitutiva;

- Expressão intracelular e ancorada à parede em diferentes bactérias lácticas: Lactococcus lactis (L. lactis)

Lactobacillus casei (L. casei)

Lactobacillus helveticus (L. helveticus)

- Imunização nasal de camundongos;

- Avaliação dos títulos de anticorpos específicos.

Em um trabalho anterior, nosso grupo mostrou a expressão de PspA em L. casei, utilizando um sistema de expressão baseado no operon da lactose desta bactéria (Oliveira et al., 2003). Entretanto, este sistema se demonstrou ineficaz na indução de anticorpos após imunização de mucosa contra este e outros antígenos expressos (Aires et al., 2006 e dados não publicados). Estes resultados levantaram dúvidas quanto ao sistema de expressão e a bactéria láctica utilizada. Por este motivo, decidiu-se utilizar o sistema de expressão constitutiva, descrito neste trabalho, que permite a expressão de antígenos em diferentes bactérias lácticas.

Após a construção dos diferentes vetores portando os genes de interesse, L. lactis e diferentes espécies de lactobacilos foram transformadas, e a expressão de PspA foi avaliada por Western-blot. Após obtenção dos clones recombinantes, eles foram testados em camundongos através de imunização nasal, para análise da indução de resposta imune humoral. Esta rota foi escolhida devido ser a via de entrada do pneumococo, o que poderia levar a uma possível proteção contra colonização e infecção por anticorpos produzidos no local. Além disso, alguns trabalhos evidenciam que a rota nasal induz maiores títulos de anticorpos em relação à imunização por via oral (Reveneau et al., 2002; Shaw et al., 2000). 


\section{MATERIAIS E MÉTODOS}

\subsection{Plasmídios, linhagens de bactérias e condições de crescimento}

O plasmídio utilizado para clonagem dos genes foi o pGEM-T (Promega), que foi utilizado para transformar E. coli DH5 $\alpha$ (Life Technologies), com o seguinte genótipo: $\left[F^{-} \phi\right.$ 80lacZAM15 $\Delta\left(\right.$ lacZYA-argF)U169 recA1 endA1 hsdR17( $\left.\mathrm{r}_{\mathrm{k}}^{-}, \mathrm{m}_{\mathrm{k}}{ }^{+}\right)$phoA supE44 thi-1 gyrA96 relA1 $\lambda^{-}$]. Esta bactéria foi crescida em meio Luria-Bertani (LB), à $37^{\circ} \mathrm{C}$ sob agitação, e conservada em $15 \%$ de glicerol à $-80^{\circ} \mathrm{C}$. Os plasmídios utilizados para expressão em LABs foram pT1NX e pT1NXssANCH, que possuem um forte promotor constitutivo (P1) isolado de L. lactis (Waterfield et al., 1995), para expressão da proteína no meio intracelular ou ancorada à parede, respectivamente. O vetor pT1NX continha a seqüência sinal $u s p S$, que foi previamente retirada para produzir as construções intracelulares. As linhagens de bactérias utilizadas para transformação com estes plasmídios foram L. lactis (MG1363), crescido em meio M17 (Difco) com adição de $0,5 \%$ de glicose à $30^{\circ} \mathrm{C}$ sem agitação; L. casei (CECT 5275) e L. helveticus (ATCC 15009), crescidos em meio MRS (Difco) à $37^{\circ} \mathrm{C}$ sem agitação, e conservados com $15 \%$ de glicerol à $-80^{\circ} \mathrm{C}$.

\subsection{Amplificação dos fragmentos pspA1', pspA3', ab1 e ab3}

Os fragmentos $p s p A 1$ ' e $p s p A 3^{\prime}$ foram amplificados por PCR a partir dos vetores pTG-pspA1 e pTG-pspA3 (Miyaji et al., 2002b) cedidos pela Dra. Eliane N. Miyaji. As reações foram realizadas com as seguintes concentrações finais de seus constituintes: $5 \mathrm{U}$ da enzima Taq DNA polimerase, 0,4mM de cada dNTP, 40pmol de cada oligonucleotídeo, $1,5 \mathrm{mM}$ de $\mathrm{MgCl}_{2}$, tampão de reação $1 \mathrm{X}$, e aproximadamente 10ng DNA molde.

- Para amplificação de $p s p A 1^{\prime}$ e $p s p A 3^{\prime}$ para posterior expressão intracelular, foram utilizados os seguintes oligonucleotídeos (clonagem no vetor pT1NX):

“Forw" - 5' ATGCATC GATATC A GAA GAA GCG CCC GTA GCT 3' Nsi I Cla I EcoR V

pspAl' Reverso - 5' TAG TTA TCT AGA TGG TTG TGG TGC TGA AG 3' (com stop códon) pspA3' Reverso - 5' TAG TTA TCT AGA TTT TGG TGC AGG AGC TGG 3' (com stop códon)

- Para amplificação de $p s p A l^{\prime}$ ' e $p s p A 3^{\prime}$ para posterior expressão ancorada à parede celular, foram utilizados os seguintes oligonucleotídeos (clonagem no vetor pT1NXssANCH):

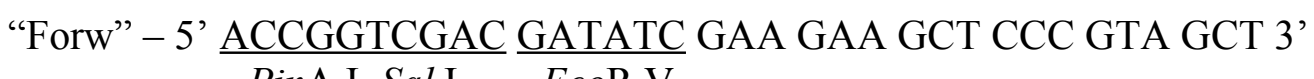
PinA I Sal I EcoR V 


\section{pspA1' Reverso - 5' GGATCC TGG TTG TGG TGC TGA AGC 3' (sem stop códon) BamH I

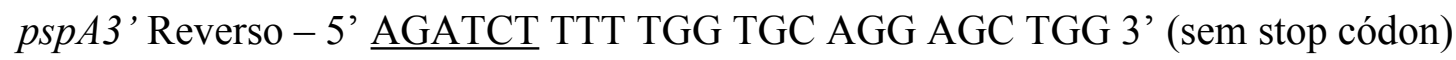 $B g l$ II}

As condições do termociclador para estas reações foram: $94^{\circ} \mathrm{C}$ por $5 \mathrm{~min},\left(94^{\circ} \mathrm{C}\right.$ por 1 $\min , 45^{\circ} \mathrm{C}$ por $45 \mathrm{seg}, 72^{\circ} \mathrm{C}$ por $\left.1,5 \mathrm{~min}\right) \times 30$ ciclos, $72^{\circ} \mathrm{C}$ por $7 \mathrm{~min}$. Após o término, foi adicionado tampão Ficoll nas reações, que foram submetidas à eletroforese em gel 1\% agarose com tampão TAE $1 \mathrm{X}$.

A amplificação dos fragmentos $a b 1$ e $a b 3$ foi feita a partir dos mesmos DNAs moldes e com o mesmo oligonucleotídeo "Forw" para expressão intracelular, porém as condições foram diferentes. As reações foram realizadas com as seguintes concentrações finais de seus constituintes: $5 \mathrm{U}$ da enzima Taq DNA polimerase, $1 \mathrm{mM}$ de cada dNTP, 60pmol de cada oligonucleotídeo, tampão de reação $1 \mathrm{X}$, e aproximadamente 10ng DNA molde. Foram feitas duas reações para cada gene variando a concentração de $\mathrm{MgCl}_{2}$. Para $a b 1$ foram feitas reações com 3 e $7 \mathrm{mM}$ de $\mathrm{MgCl}_{2}$ e para ab3 foram feitas reações com 1,5 e $5 \mathrm{mM}$. Os oligonucleotídeos reversos utilizados foram:

$a b 1: 5^{\prime}$ GGT ACC TTA TTC TGG CTC ATT AAC TGC 3' (com stop códon) Kpn I

ab3: 5' GGT ACC TTA TTC TTC TTC ATC TCC ATC AGG 3' (com stop códon) Kpn I

As condições do termociclador para estas reações foram: $94^{\circ} \mathrm{C}$ por $5 \mathrm{~min},\left(94^{\circ} \mathrm{C}\right.$ por 1 $\min , 45^{\circ} \mathrm{C}$ por $50 \mathrm{seg}, 72^{\circ} \mathrm{C}$ por $\left.1,5 \mathrm{~min}\right) \mathrm{x} 30$ ciclos, $72^{\circ} \mathrm{C}$ por $7 \mathrm{~min}$. Após o término, foi adicionado tampão Ficoll nas reações, que foram submetidas a eletroforese em gel 1\% agarose com tampão TAE $1 \mathrm{X}$.

Todos os fragmentos amplificados foram purificados, ligados ao vetor de clonagem pGEM-T (Promega) e utilizados para transformar E. coli DH5 $\alpha$ competentes, por choque térmico $\left(42^{\circ} \mathrm{C}\right.$ por $\left.2 \mathrm{~min}\right)$. Após choque térmico as bactérias foram incubadas no gelo por 5 min, diluídas em $450 \mu \mathrm{L}$ de meio $\mathrm{LB}$ e incubadas a $37^{\circ} \mathrm{C}$ por $1 \mathrm{~h}$. O volume total foi plaqueado em 3 placas LB-ágar contendo $100 \mu \mathrm{g}$ ampicilina $/ \mathrm{mL}$, que foram incubadas a $37^{\circ} \mathrm{C}$ por aproximadamente $18 \mathrm{~h}$. Dos clones positivos foram extraídos os plasmídeos, que foram preparados utilizando o kit "GFX Micro Plasmid Prep Kit" (GE Helthcare), que depois foram confirmados por sequenciamento. 


\subsection{Reações de digestão}

Após confirmação por sequenciamento, os insertos foram digeridos com as enzimas de restrição apropriadas, por 1 hora nas temperaturas adequadas a cada enzima:

- Os insertos para serem utilizados nas construções de expressão intracelular foram digeridos com a enzima Nde I utilizando o tampão apropriado, e depois foram tratados com a enzima Klenow para preenchimento da extremidade coesiva formando uma extremidade abrupta ("blunt”). Depois, o fragmento obtido foi digerido com a enzima Nsi I, utilizando o tampão apropriado.

- O vetor pT1NX foi preparado previamente para digestão. Para isto, foram retirados os múltiplos sítios de Pst I que existiam no vetor, através de PCR, gerando mutações pontuais nos sítios de restrição. Depois a seqüência sinal uspS (vista na figura 3) foi retirada por PCR (dados não mostrados). Este vetor modificado foi digerido no sítio BamH I utilizando o tampão apropriado, e depois tratamento com a enzima Klenow para preenchimento da extremidade coesiva formando uma extremidade abrupta ("blunt"). Após purificação, o vetor foi digerido com Pst I (dados não mostrados).

- Os insertos para serem utilizados nas construções de ancoramento à parede foram digeridos com as enzimas PinA I e BamH I para $p s p A 1$ '; PinA I e $B g l$ II para $p s p A 3$, utilizando os tampões apropriados.

- O vetor pT1NXssANCH foi digerido nos sítios NgoM IV e BamH I, utilizando o tampão apropriado. A figura 4 mostra o mapa do vetor utilizado.

Após o término das reações, foi adicionado o tampão Ficoll nas amostras, que foram submetidas a eletroforese em gel 1\% agarose com tampão TAE 1X. Os fragmentos de DNA foram excisados e purificados com o kit "GFX PCR DNA and Gel purification kit" (GE Helthcare).

\subsection{Reações de ligação}

Após a digestão e purificação, os diferentes fragmentos de $p s p A$ foram clonados nos vetores pT1NX e pT1NXssANCH. Para todas as construções, as reações de ligação foram feitas a $16^{\circ} \mathrm{C}$, por $18 \mathrm{~h}$, em tampão de ligação, com $5 \mathrm{U}$ de T4 DNA ligase, e em volume final de $20 \mu \mathrm{L}$. Após estas reações, os produtos de ligação foram precipitados com $\mathrm{NaAc} 0,3 \mathrm{M}$ e etanol $75 \%$, a $20^{\circ} \mathrm{C}$ por $18 \mathrm{~h}$. Os precipitados foram lavados em etanol $70 \%$, centrifugados a $14.000 \mathrm{rpm}$ por $5 \mathrm{~min}$, e após a retirada do etanol do "pellet" a $37^{\circ} \mathrm{C}$, eles foram ressuspendidos em $5 \mu \mathrm{L}$ de água. O volume total foi utilizado para transformação de L. lactis. 


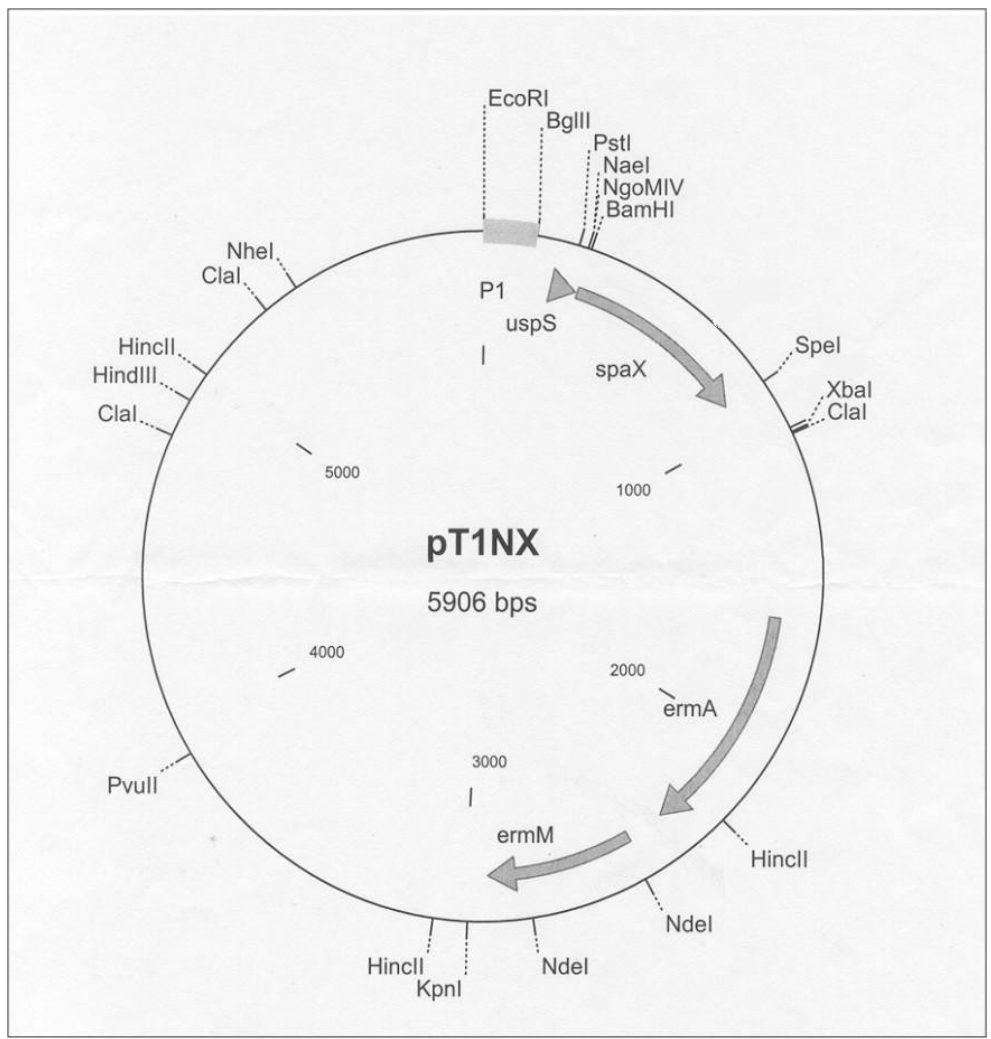

Fig. 3 - Mapa do vetor pT1NX para expressão intracelular. Neste esquema está simbolizado o gene uspS, referente o peptídeo sinal, que foi retirado previamente.

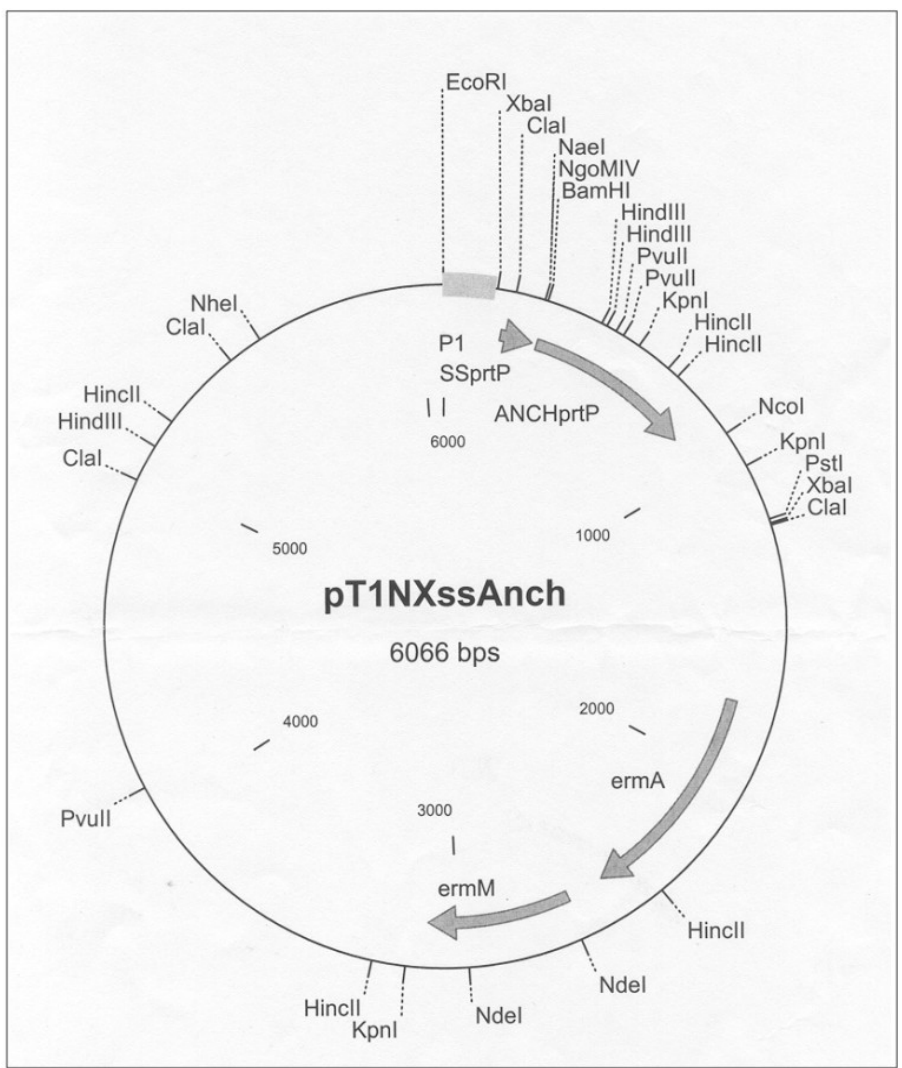

Fig. 4 - Mapa do vetor pT1NXssAnch para expressão da proteína ancorada à parede celular. 


\subsection{Preparação de Lactococcus lactis competente e transformação}

A partir de uma cultura crescida por aproximadamente $18 \mathrm{~h}$, preparou-se uma diluição 1:30 do cultivo, em meio GM17, que corresponde ao meio M17 (Difco) com 0,5\% de glicose, contendo $1 \%$ glicina. A cultura foi mantida a $30^{\circ} \mathrm{C}$ até atingir a $\mathrm{DO}_{600}$ (Densidade óptica à $600 \mathrm{~nm}$ ) entre 0,5 e 0,7 . As células foram coletadas por centrifugação a $10.000 \mathrm{rpm}, 10 \mathrm{~min}$. O "pellet" foi lavado $2 \mathrm{X}$ com tampão de eletroporação para lactococos e ressuspenso em um volume equivalente a 1:100 do volume original da cultura. Todo o processo foi feito no gelo. As células foram divididas em alíquotas de $50 \mu \mathrm{L}$ e congeladas a $-80^{\circ} \mathrm{C}$, sendo que a viabilidade da bactéria é de um mês. O produto da reação de ligação, após a lavagem, foi colocado em cubetas de $0,2 \mathrm{~cm}$ junto com uma das alíquotas de células. A eletroporação foi realizada a $2500 \mathrm{~V}, 200 \mathrm{Ohm}$ e $25 \mu \mathrm{F}$. O material foi ressuspendido em $5 \mathrm{~mL}$ de GM17 contendo $0,5 \mathrm{M}$ de sacarose $+20 \mathrm{mM} \mathrm{MgCl}_{2}+1 \mathrm{mM} \mathrm{CaCl}_{2}$ e incubado a $30^{\circ} \mathrm{C}$ por $2 \mathrm{~h}$. Depois, foi centrifugado a $4.000 \mathrm{rpm}$ por $20 \mathrm{~min}$ e ressuspendido em $500 \mu \mathrm{L}$ do mesmo meio. O volume total foi dividido em duas placas de GM17 contendo $0,5 \mathrm{M}$ de sacarose e $5 \mu \mathrm{g}$ eritromicina $/ \mathrm{mL}$. Após um dia, observa-se o aparecimento de colônias resistentes. Os clones obtidos após as transformações foram crescidos em meio líquido GM17 com $5 \mu \mathrm{g}$ eritromicina $/ \mathrm{mL}$ a $30^{\circ} \mathrm{C}$ por 18h, para posterior congelamento e análise da expressão da proteína heteróloga.

\subsection{Análise dos clones recombinantes de Lactococcus lactis por PCR}

Alguns clones resistentes ao antibiótico, para todas as construções realizadas, foram crescidos em $1 \mathrm{~mL}$ de meio GM17 com $5 \mu \mathrm{g}$ eritromicina/mL por $18 \mathrm{~h}$, para serem analisados quanto à presença do gene de interesse por PCR. Para isso, centrifugou-se $150 \mu \mathrm{L}$ de cultura, e o "pellet" de bactérias foi ressuspendido em $5 \mu \mathrm{L}$ de água. Neste material foram acrescentados os constituintes da PCR para uma concentração final de: $0,3 \mathrm{mM}$ de cada dNTP, 0,4 pmol de cada oligonucleotídeo, $1,5 \mathrm{mM}$ de $\mathrm{MgCl}_{2}$, tampão de reação $1 \mathrm{X}$ e 7,5U da enzima Taq DNA polimerase. Os oligonucleotídeos utilizados foram:

P1 "Forw": 5' AGA TAT GTT ATA ATA CAA GTA TCA GAT C 3', que se liga no promotor P1 dos vetores pT1NX e pT1NXssANCH;

Reverso: o mesmo utilizado para a amplificação de cada gene.

As condições do termociclador para estas reações foram: $95^{\circ} \mathrm{C}$ por $4 \mathrm{~min},\left(95^{\circ} \mathrm{C}\right.$ por 30 seg, $45^{\circ} \mathrm{C}$ por $30 \mathrm{seg}, 72^{\circ} \mathrm{C}$ por $1,5 \mathrm{~min}$ )x 35 ciclos, $72^{\circ} \mathrm{C}$ por $3 \mathrm{~min}$. Após o término, foi adicionado tampão Ficoll nas reações, que foram submetidas à eletroforese em gel 1\% agarose com tampão TAE $1 \mathrm{X}$. 


\subsection{Preparação de DNA plasmidial em pequena escala}

Um clone de L. lactis positivo no PCR, para cada construção realizada, foi inoculado em $5 \mathrm{ml}$ de meio GM17 contendo $5 \mu \mathrm{g}$ eritromicina/mL e incubado a $30^{\circ} \mathrm{C}$ por aproximadamente $18 \mathrm{~h}$. As bactérias foram coletadas por centrifugação a $14.000 \mathrm{rpm}$ por $5 \mathrm{~min}$, e depois foram ressuspendidas em um volume equivalente a 1:10 do volume original da cultura com uma solução de $20 \mathrm{mg} / \mathrm{mL}$ de lisozima (Sigma) em tampão GTE. O material foi incubado por 1 hora a $37^{\circ} \mathrm{C}$, depois centrifugado novamente. $\mathrm{O}$ "pellet" foi utilizado para preparação dos plasmídios utilizando o kit "GFX Micro Plasmid Prep Kit" (GE Healthcare) de acordo com as instruções do fabricante.

\subsection{Preparação de Lactobacillus casei competente e transformação}

A partir de uma cultura crescida por aproximadamente $18 \mathrm{~h}$, preparou-se uma diluição 1:30 do cultivo, em MRS (Difco) contendo 1\% glicina. A cultura foi mantida a $37^{\circ} \mathrm{C}$ até atingir a $\mathrm{DO}_{550}$ entre 0,4 e 0,6 . As células foram coletadas por centrifugação a $10.000 \mathrm{rpm}$, 10min. O "pellet" foi lavado $2 \mathrm{X}$ com tampão de eletroporação para $L$. casei e ressuspenso em um volume equivalente a 1:100 do volume original da cultura. Todo o processo foi feito no gelo. As células foram divididas em alíquotas de $50 \mu \mathrm{L}$ e misturadas com $5 \mu \mathrm{L}$ de mini-prep de cada construção. A eletroporação foi realizada em cubetas de $0,2 \mathrm{~cm}, 1500 \mathrm{~V}, 200 \mathrm{Ohm}$ e $25 \mu \mathrm{F}$. Depois, foram adicionados $950 \mu \mathrm{L}$ de meio MRS contendo $0,3 \mathrm{M}$ sacarose; $20 \mathrm{mM} \mathrm{MgCl}_{2} \mathrm{e}$ $2 \mathrm{mM} \mathrm{CaCl} \mathrm{Cl}_{2}$ e incubou-se as células a $37^{\circ} \mathrm{C}$ por $1,5 \mathrm{~h}$. Diferentes alíquotas do volume total de cada transformação foram plaqueadas em três placas de MRS contendo $5 \mu \mathrm{g}$ eritromicina $/ \mathrm{mL}$. Após 3 dias observa-se o aparecimento de colônias resistentes. Os clones obtidos após as transformações foram crescidos em meio líquido MRS com $5 \mu \mathrm{g}$ eritromicina/mL a $37^{\circ} \mathrm{C}$ por 18h, para posterior congelamento e análise da expressão da proteína heteróloga.

\subsection{Preparação de Lactobacillus helveticus competente e transformação}

O mesmo DNA plasmidial utilizado para transformação de $L$. casei foi utilizado para transformação de L. helveticus, conforme protocolo a seguir:

A partir de uma cultura de $2 \mathrm{~mL}$ crescida por $24 \mathrm{~h}$ a $37^{\circ} \mathrm{C}$, acrescentou-se meio MRS para $5 \mathrm{~mL}$ e incubou-se por mais $24 \mathrm{~h}$. Depois esta mesma cultura foi completada para $20 \mathrm{~mL}$ com o mesmo meio, contendo $1 \%$ glicina, até atingir a $\mathrm{DO}_{660}$ entre 0,5 e 0,6 . As células foram coletadas por centrifugação a $10.000 \mathrm{rpm}, 10 \mathrm{~min}$. O "pellet" foi lavado $2 \mathrm{X}$ com $20 \mathrm{~mL}$ do tampão de eletroporação para L. helveticus, $1 \mathrm{X}$ com $5 \mathrm{~mL}$ do mesmo tampão, e foi 
ressuspenso em um volume equivalente a 1:100 do volume original da cultura. Todo o processo foi feito no gelo. As células foram divididas em alíquotas de $60 \mu \mathrm{L}$ e misturadas com $10 \mu \mathrm{L}$ de mini-prep de cada construção. A eletroporação foi realizada em cubetas de $0,2 \mathrm{~cm}$, $2500 \mathrm{~V}, 200 \mathrm{Ohm}$ e $25 \mu \mathrm{F}$. Após o choque, foram adicionados $950 \mu \mathrm{L}$ de meio MRS contendo $0,3 \mathrm{M}$ sacarose; $20 \mathrm{mM} \mathrm{MgCl}_{2}$ e $2 \mathrm{mM} \mathrm{CaCl}_{2}$ e incubou-se as células a $37^{\circ} \mathrm{C}$ por $2 \mathrm{~h}$. Em duas placas de MRS contendo $5 \mu \mathrm{g}$ eritromicina $/ \mathrm{mL}$ foram plaqueados $500 \mu \mathrm{L}$ de cada cultura. Após 4 a 6 dias observou-se o aparecimento de poucas colônias resistentes. Estas colônias foram crescidas em meio líquido MRS com $5 \mu \mathrm{g}$ eritromicina $/ \mathrm{mL}$ a $37^{\circ} \mathrm{C}$ por 2 a 3 dias, para posterior congelamento e análise da expressão da proteína heteróloga.

\subsection{Análise da expressão constitutiva das proteínas heterólogas em Lactococcus lactis, Lactobacillus casei e Lactobacillus helveticus, por Western-blot}

Algumas colônias resistentes obtidas após a transformação de cada bactéria foram crescidas em seus respectivos meios líquidos com antibiótico, e depois foram aliquotadas para conservação a $-80^{\circ} \mathrm{C}$ com glicerol. O restante da cultura foi centrifugado a 4.000rpm por 20 min para a análise da expressão da proteína heteróloga. O "pellet", contendo as bactérias, foi ressuspendido em 1:10 do volume inicial com 100mM Tris- $\mathrm{HCl} \mathrm{pH} 8$ contendo coquetel de inibidores de proteases (Sigma). Depois, o material foi transferido para um tubo contendo o mesmo volume de "contas" de vidro (glass beads -106 microns, Sigma), e as bactérias foram lisadas mecanicamente neste tubo, por agitação em aparelho "Bead-beater". Posteriormente, coletou-se o lisado em outro tubo para conservação a $-20^{\circ} \mathrm{C}$. Para cada lisado, separaram-se $20 \mu \mathrm{L}$ onde foram acrescentados $5 \mu \mathrm{L}$ de tampão de amostra $5 \mathrm{X}$ para SDS-PAGE.

Para a análise do meio de cultura, foram aliquotados $200 \mu \mathrm{L}$ do sobrenadante após centrifugação das culturas bacterianas, que foram secados em "Speed-Vac", e ressuspendidos em $20 \mu \mathrm{L}$ de tampão de amostra $1 \mathrm{X}$ para SDS-PAGE. As amostras dos lisados e dos sobrenadantes do meio de cultura foram aquecidas a $98^{\circ} \mathrm{C}$ por $10 \mathrm{~min}$, e após a preparação, foram separadas por SDS-PAGE 10\%, em tampão Tris-glicina $1 \mathrm{X}$.

Os géis de poliacrilamida foram transferidos para membranas de nitrocelulose a uma corrente de 350mA por 1,5h. Estas membranas foram bloqueadas com 10\% leite diluído em tampão PBS-T a $4^{\circ} \mathrm{C}$ por $18 \mathrm{~h}$. Após o bloqueio, as membranas foram incubadas com anticorpos específicos (anti-PspA1' ou anti-PspA3') diluídos em 2\% leite PBS-T, por 1,5h em temperatura ambiente, sob agitação. Estes anticorpos foram obtidos a partir de soro de 
camundongos, após administração intraperitoneal das proteínas recombinantes produzidas neste laboratório, que foram previamente purificadas de E. coli. Depois, foram feitas 3 lavagens de 10min sob agitação com PBS-T. O segundo anticorpo (anti-IgG de camundongo conjugado a peroxidase), também diluído em 2\% leite PBS-T, foi incubado por $1 \mathrm{~h}$ em temperatura ambiente, sob agitação. Foram feitas 3 lavagens novamente com PBS-T, para que as membranas fossem reveladas com o Kit ECL utilizando o filme de Raio X "hyper film" (ambos da GE Healthcare).

\subsection{Análise da exposição da proteína heteróloga nas bactérias lácticas íntegras.}

Clones de L. lactis e L. casei foram avaliados quanto a exposição da proteína heteróloga na parede celular. Para isso, cresceu-se um clone de cada construção (intracelular e de ancoramento à parede), de cada bactéria láctica, em seu respectivo meio com antibiótico, além do clone controle que só possui o vetor sem os genes de interesse. As culturas foram crescidas até atingir DO entre 1,5 e 1,7 (600nm para L. lactis e 550nm para L. casei). Foram coletadas duas alíquotas de $1 \mathrm{~mL}$ para cada clone, que foram centrifugadas a 4000rpm, por 20min. Os "pellets" foram lavados com tampão PBS 1X para retirada do meio de cultura, e centrifugados novamente nas mesmas condições. A seguir, os "pellets" foram ressuspendidos com $500 \mu \mathrm{L}$ de uma solução de PBS 1X com 1\% BSA (Albumina de soro bovino - Fisher) e os anticorpos específicos (anti-PspA1' ou anti-PspA3'). Agitou-se por 1,5h a $2 \mathrm{~h}$ em temperatura ambiente, depois centrifugou-se a 10000rpm por 6min, e os "pellets" foram lavados $2 \mathrm{X}$ com $500 \mu \mathrm{L}$ de PBS $1 \mathrm{X}$. O segundo anticorpo (anti-IgG de camundongo conjugado a peroxidase), também diluído em PBS 1X com 1\% BSA, foi adicionado aos "pellets" de células lavadas em volume final de $500 \mu \mathrm{L}$. As amostras foram incubadas por $1 \mathrm{~h}$ à temperatura ambiente, sob agitação. Centrifugou-se nas mesmas condições, e depois foram feitas 2 lavagens novamente com PBS 1X. Foram colocados $100 \mu \mathrm{L}$ de cada suspensão bacteriana em placa de ELISA com 96 poços e depois adicionou-se $100 \mu \mathrm{L}$ de uma solução de $20 \mathrm{~mL}$ de tampão citrato-fosfato $0,1 \mathrm{M}$, com $8 \mathrm{mg}$ de $\mathrm{OPD}$ (o-fenilenodiamina) e $10 \mu \mathrm{L}$ de $\mathrm{H}_{2} \mathrm{O}_{2}$ em cada poço. Incubou-se por 40min no escuro. Após este período, as placas foram centrifugadas por $2 \mathrm{~min}$ a $4000 \mathrm{rpm}$, e coletou-se $100 \mu \mathrm{L}$ de cada poço que foram passados para poços de uma nova placa. Nestes poços foram adicionados $50 \mu \mathrm{L}$ de $\mathrm{H}_{2} \mathrm{SO}_{4} 8 \mathrm{~N}$ para interromper a reação. A leitura foi feita em leitor de ELISA a 492nm. 


\subsection{Curva de crescimento das bactérias recombinantes}

Algumas bactérias portando os genes de interesse ou os vetores vazios foram crescidas em meio líquido, a fim de se acompanhar a curva de crescimento das mesmas. Para isso, foi feito um inóculo inicial, até a cultura 1 chegar à sua DO máxima de crescimento. L. lactis foi crescido em meio GM17 (meio Difco com adição de glicose), enquanto que $L$. casei e $L$. helveticus foram crescidos em meio MRS (Difco), todos com $5 \mu \mathrm{g} / \mathrm{mL}$ do antibiótico eritromicina. Depois, aliquotou-se destas culturas um volume suficiente para produzir novos inóculos com DO igual a 0,1. Então, acompanhou-se a DO destas novas culturas pelo tempo, até a fase estacionária das bactérias. Em algumas DOs, foram feitas diluições seriadas das bactérias. Para isso, aliquotou-se $10 \mu \mathrm{L}$ de cada cultura, e seguiu-se com diluições seriadas de 1:10 em salina. Estas diluições foram plaqueadas nos respectivos meios-ágar de cada bactéria, com antibiótico. As placas foram, posteriormente, incubadas a $30^{\circ} \mathrm{C}$ por 1dia para L. lactis, a $37^{\circ} \mathrm{C}$ por 2 dias para L. casei, e por 3 a 4 dias para L. helveticus, para posterior contagem do número de CFU.

\subsection{Quantificação de PspA produzida pelas bactérias recombinantes}

As bactérias expressando as proteínas heterólogas foram avaliadas quanto à quantidade de proteína produzida. Para L. casei, as culturas foram crescidas até uma DO de aproximadamente 1,5 , que correspondia a aproximadamente $10^{8} \mathrm{CFU} / \mu \mathrm{L}$. Foram aliquotados $1 \mathrm{~mL}$ de cada cultura, e centrifugou-se a 4000rpm por 20min. Os "pellets" foram ressuspendidos com $1 \mathrm{~mL}$ do tampão utilizado na lise mecânica (vide item 3.10). No gel de poliacrilamida, foram aplicados apenas $10 \mu \mathrm{L}$ de cada lisado, que correspondem a $10^{9}$ bactérias. Ao lado dos lisados, aplicou-se uma curva de PspA recombinante purificada de $E$. coli, obtida após diluição seriada de 1:2.

Para L. helveticus, as culturas foram crescidas até uma DO de aproximadamente 1,4. Foram aliquotados $1 \mathrm{~mL}$ de cada cultura, e centrifugou-se a 4000rpm por 20min. Os "pellets" foram ressuspendidos com $70 \mu \mathrm{L}$ do tampão utilizado na lise mecânica. No gel de poliacrilamida, foram aplicados $40 \mu \mathrm{L}$ de cada lisado, que correspondem a aproximadamente $10^{7}$ bactérias. Ao lado dos lisados, também se aplicou uma curva de PspA recombinante, obtida após diluição seriada de 1:2.

As quantidades das proteínas de interesse das bactérias recombinantes foram estimadas no aparelho "Eagle-Eye", que utilizou como padrão as curvas de PspA purificadas de E. coli. 


\subsection{Imunização de camundongos}

Para avaliação da resposta imune humoral de camundongos contra o antígeno PspA, camundongos C57Bl/6 fêmeas, de 5 a 7 semanas de vida, foram imunizados por via intranasal, com as bactérias lácticas expressando PspA1'. Estes experimentos foram realizados como um teste inicial, para avaliar o potencial destas bactérias de induzir o sistema imune dos animais. As condições controle dos experimentos correspondem aos animais imunizados com as mesmas bactérias portando o vetor vazio, ou apenas salina estéril. Os controles foram realizados nas mesmas condições das bactérias recombinantes portando PspA1'. Para estes testes, as bactérias foram crescidas até DO máxima de crescimento (em média), ou seja, foram coletadas em sua fase estacionária. Os volumes aliquotados por animal foram centrifugados a 10000rpm por 6min, e os "pellets" foram lavados $2 \mathrm{X}$ com solução salina estéril, e então ressuspendidos em $10 \mu \mathrm{L}$ de solução salina para cada animal.

Cada grupo continha seis animais, que receberam via intranasal $10 \mu \mathrm{L}$ das suspensões bacterianas, ou apenas solução salina para o controle negativo, após administração de um coquetel de anestésicos $(0,2 \%$ xilazina $+0,5 \%$ quetamina $)$ injetado via intraperitoneal. $\mathrm{O}$ protocolo utilizado foi o mais comumente utilizado na literatura, composto de 3 imunizações a cada 14 dias, sendo que cada uma era constituída de 2 doses em dias consecutivos. Entre 11 e 14 dias após a última imunização, o sangue e a saliva foram coletados dos animais. $\mathrm{O}$ sangue foi coletado individualmente pelo plexo retrorbital. Após a coleta do sangue, as amostras foram incubadas por $30 \mathrm{~min}$ a $37^{\circ} \mathrm{C}$ e por $10 \mathrm{~min}$ a $4^{\circ} \mathrm{C}$ para retrair o coágulo formado. Então, foram centrifugadas a $2000 \mathrm{rpm}$ por $10 \mathrm{~min}$ a $4^{\circ} \mathrm{C}$ para a coleta do sobrenadante que corresponde ao soro. A saliva dos animais foi coletada em "pool" de um mesmo grupo, após a estimulação com injeção intraperitoneal de $500 \mu \mathrm{L}$ de salina contendo 40 $\mu \mathrm{g}$ de pilocarpina por animal.

Em um ensaio preliminar, os animais C57B1/6, 2 dias após a coleta do material, foram desafiados. Para isso, a cepa de S. pneumoniae 491/00 (Instituto Adolfo Lutz, São Paulo), cuja proteína PspA pertence ao clado 1, foi crescida em meio THY líquido (Todd Hewitt Broth contendo $0,5 \%$ de extrato de levedura) até atingir a fase exponencial $\left(\mathrm{OD}_{660}=0.4\right.$ a 0.6$)$. As bactérias foram centrifugadas a 4000rpm, por 20min, e depois foram suspensas em 1:10 do volume inicial, em meio contendo $15 \%$ de glicerol. Alíquotas de $100 \mu \mathrm{L}$ foram mantidas a $-80^{\circ} \mathrm{C}$. Após o congelamento, um dos tubos foi descongelado e diluições foram plaqueadas em ágar-sangue, para a análise da viabilidade celular. As alíquotas podem ser mantidas a $-80^{\circ} \mathrm{C}$ 
por meses. Sempre que necessário, a viabilidade celular é testada novamente. Os camundongos $\mathrm{C} 57 \mathrm{Bl} / 6$ foram inoculados com $2 \times 10^{6} \mathrm{CFU}$ em $500 \mu \mathrm{L}$ pela via intraperitoneal. Estes animais foram acompanhados por 15 dias para observação da sobrevivência pósdesafio.

\subsection{Análise preliminar da produção de anticorpos anti-PspA' em camundongos após $3^{\mathrm{a}}$ imunização}

Placas de ELISA foram sensibilizadas com $1 \mu \mathrm{g}$ por poço da proteína PspA1' recombinante purificada de E. coli neste laboratório. Para isso, as proteínas foram diluídas em tampão $0,05 \mathrm{M}$ carbonato-bicarbonato, e incubadas por $18 \mathrm{~h}$ a $4^{\circ} \mathrm{C}$. Após a incubação as placas foram lavadas $3 \mathrm{X}$ com PBS-T. Depois, foi feito o bloqueio com 10\% leite diluído em PBS-T por $1 \mathrm{~h}$ a $37^{\circ} \mathrm{C}$, e novamente, 3 lavagens com PBS-T. Para a incubação do soro dos animais, adicionou-se $10 \mu \mathrm{L}$ por poço do soro de cada animal em $190 \mu \mathrm{L}$ de PBS-T com $1 \%$ BSA contidos em cada poço, iniciando portanto com uma diluição de 1:20 e seguiu-se com diluições seriadas de 1:2. Para a saliva, adicionou-se $25 \mu \mathrm{L}$ de cada amostra (referente a cada condição) por poço em $75 \mu \mathrm{L}$ da solução de PBS-T com 1\% BSA contidos em cada poço, iniciando portanto com uma diluição de 1:4 e seguiu-se com diluições seriadas de 1:2. Todas as placas foram incubadas por $1,5 \mathrm{~h}$ a $37^{\circ} \mathrm{C}$.

Após 3 lavagens com PBS-T, foi feita a incubação por $1 \mathrm{~h}$ a $37^{\circ} \mathrm{C}$ do segundo anticorpo (anti-IgG ou anti-IgA de camundongo conjugado a peroxidase), que foi diluído em

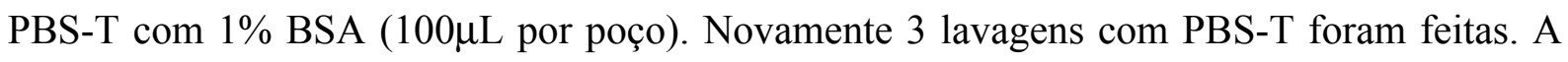
revelação foi feita com $100 \mu \mathrm{L}$ por poço de uma solução de $20 \mathrm{~mL}$ de tampão citrato-fosfato $0,1 \mathrm{M}$, contendo $8 \mathrm{mg}$ de $\mathrm{OPD}$ e $10 \mu \mathrm{L}$ de $\mathrm{H}_{2} \mathrm{O}_{2}$. Incubou-se por $15 \mathrm{~min}$ no escuro e adicionouse $50 \mu \mathrm{L}$ de $\mathrm{H}_{2} \mathrm{SO}_{4} 8 \mathrm{~N}$ para interromper a reação. A leitura foi feita em leitor de ELISA a 492nm. Depois, as diferenças nos títulos de anticorpos foram analisados pelo teste estatístico Mann-Whitney $U$. 


\section{Resultados e Discussão}

\subsection{Amplificação dos fragmentos $p \operatorname{spA1}$ ' e $p s p A 3$ '}

Os genes $p s p A 1$ ' e $p s p A 3$ ' foram amplificados por PCR utilizando os vetores pTGpspA1 e pTG-pspA3 como molde. A figura 5 mostra o gel de agarose $1 \%$ com a amplificação dos genes utilizando os oligonucleotídeos para construção intracelular. Pode-se observar uma banda específica, nas duas reações, correspondendo ao tamanho esperado dos fragmentos de aproximadamente $975 \mathrm{pb}$ para $p s p A 1$ ' e de $1050 \mathrm{pb}$ para $p s p A 3$ '.

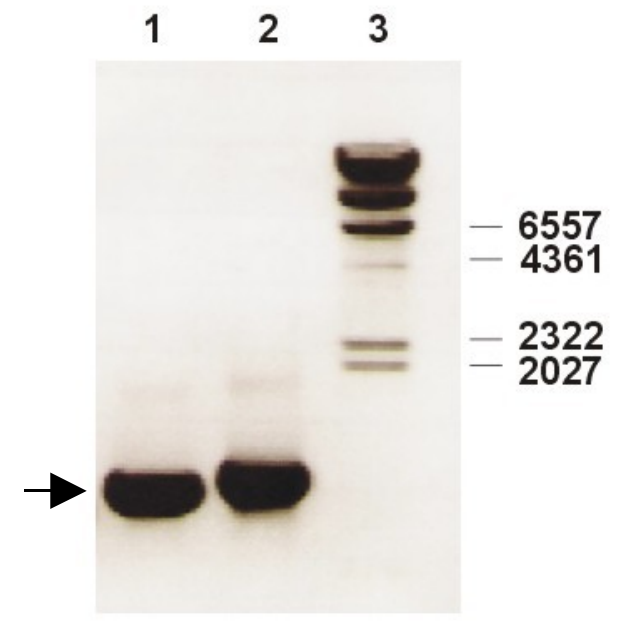

Fig. 5 - Produtos de PCR dos fragmentos para expressão intracelular: (1) pspAl'; (2) pspA3'; (3) marcador molecular $\lambda /$ Hind III; A seta indica as bandas correspondentes aos genes amplificados.

A figura 6 mostra a foto do gel de agarose 1\% com a amplificação por PCR dos fragmentos $p s p A 1$ ' e $p s p A 3$ ' para as construções de ancoramento à parede. Este PCR teve como DNA molde os mesmos vetores utilizados para a construção intracelular, porém foram utilizados oligonucleotídeos diferentes para estas construções. Da mesma forma que na amplificação dos genes para a construção intracelular, obteve-se uma banda específica, correspondendo ao tamanho esperado de aproximadamente $975 \mathrm{pb}$ para $p s p A 1$ ' e 1050pb para pspA3'. 


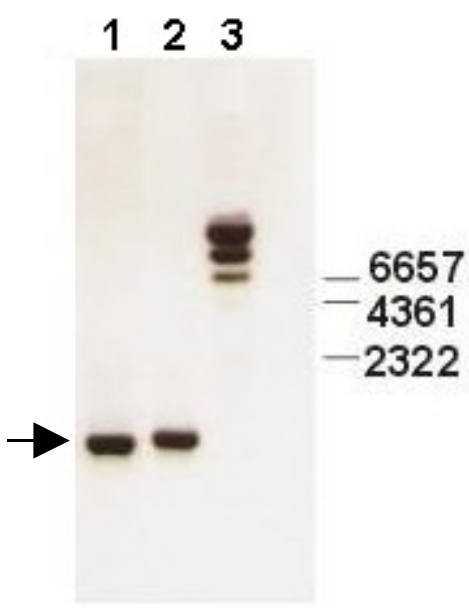

Fig. 6 - Produtos de PCR dos fragmentos para expressão da proteína ancorada à parede: (1) pspA1'; (2) pspA3'; (3) marcador molecular $\lambda /$ Hind III; A seta indica as bandas correspondentes aos genes amplificados.

\subsection{Amplificação dos fragmentos $a b 1$ e $a b 3$}

A amplificação do fragmento $a b 1$ por PCR também foi feita a partir do vetor pTGpspA1. O oligonucleotídeo utilizado no sentido de leitura do gene ("forward") foi o mesmo para a construção intracelular do $p s p A 1$, , sendo que o reverso foi o oligonucleotídeo que se anela à janela $\mathrm{B}$ do gene, excluindo a região de prolina (janela $\mathrm{C}$ ), vide figura 2. A figura 7 mostra o gel de agarose $1 \%$ com a amplificação de uma banda específica, que corresponde ao tamanho esperado para $a b 1$ de aproximadamente $860 \mathrm{pb}$. Duas condições de PCR foram testadas (3 e $7 \mathrm{mM}$ de $\mathrm{MgCl}_{2}$ ), entretanto, o produto só foi obtido na condição de maior concentração de sal, conforme visto no canal 1 da figura 7 .

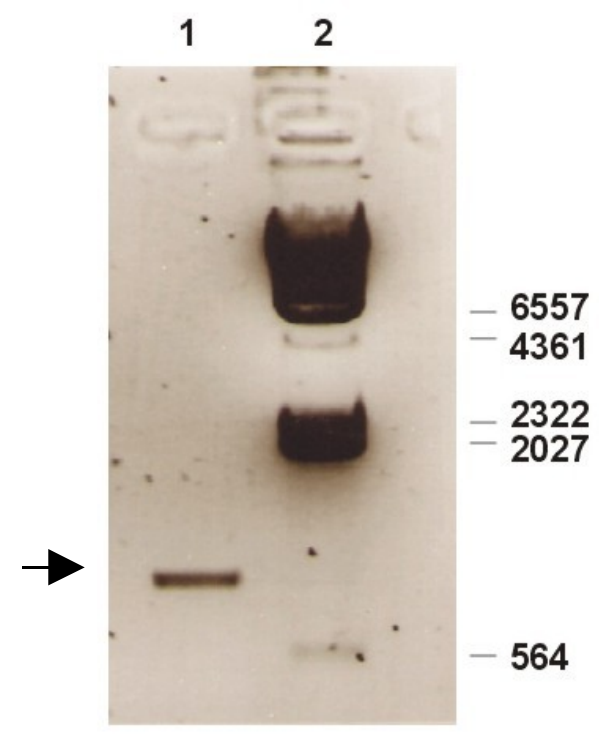

Fig. 7 - Produto de PCR do fragmento para expressão intracelular: (1) $a b 1$; (2) marcador molecular $\lambda /$ Hind III; A seta indica a banda correspondente a amplificação do gene. 
O gene $a b 3$ foi amplificado com o mesmo DNA molde e oligonucleotídeo utilizados para a construção intracelular de $p s p A 3$ ', exceto o oligonucleotídeo reverso, pois ele também se anela na janela $\mathrm{B}$ do gene, assim como para $a b 1$. A figura 8 mostra o gel de agarose $1 \%$ das duas reações de PCR testadas, de 1,5 e $5 \mathrm{mM}$ de $\mathrm{MgCl}_{2}$. Ambas as reações promoveram a amplificação do gene, que teve o tamanho esperado de 980pb aproximadamente.

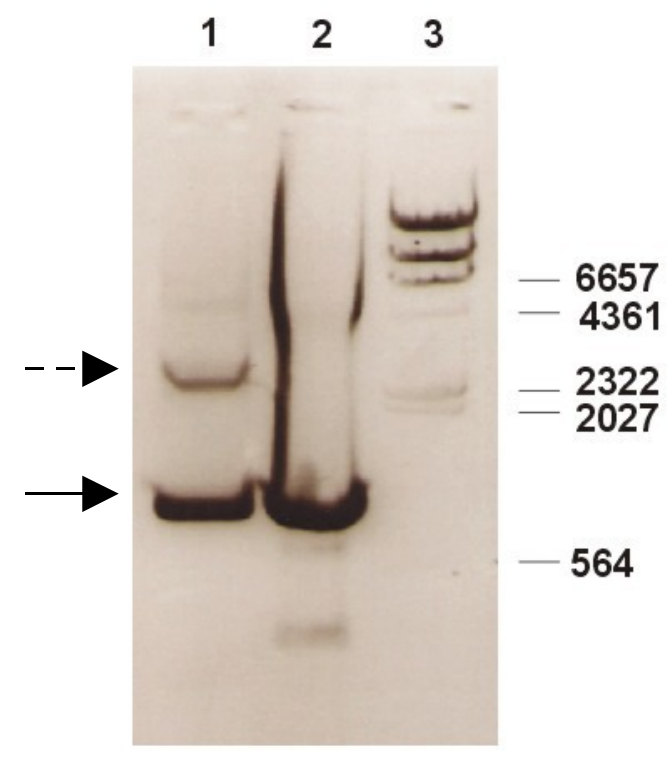

Fig. 8 - Produto de PCR do fragmento para expressão intracelular: (1) ab3 na condição de 1,5mM de $\mathrm{MgCl}_{2}$; (2) ab3 na condição de $5 \mathrm{mM}$ de $\mathrm{MgCl}_{2}$; (3) marcador molecular $\lambda /$ Hind III; A seta cheia indica as bandas específicas correspondentes às amplificações do gene; A seta tracejada indica a banda do vetor utilizado para amplificação.

\subsection{Reações de digestão}

Após confirmação por sequenciamento, os fragmentos pspA1' e pspA3', correspondentes às construções de expressão intracelular, foram obtidos por digestão dos vetores pGEM-T-pspA1' e pGEM-T-pspA3'. Foi utilizada a enzima de restrição Nde I, e depois tratamento com a enzima Klenow para formar a extremidade abrupta ("blunt"). Esta extremidade é compatível com a extremidade 3' não coesiva do vetor de expressão pT1NX, após a digestão do mesmo (foto não mostrada). Após a purificação da primeira digestão, o produto foi digerido com a enzima $N s i$ I, e foram obtidos fragmentos do tamanho esperado de pspA1' de 975pb e $p s p A 3$ ' de 1050pb, aproximadamente, conforme mostra a figura 9 do gel de agarose $1 \%$. A enzima Nsi I, cujo sítio está localizado à 5 ' do gene, foi utilizada na digestão dos fragmentos para todas as construções de expressão intracelular. Ela foi escolhida por formar extremidade compatível com Pst I, que é o sítio escolhido no vetor de expressão intracelular (pT1NX) para a ligação dos genes de interesse. 


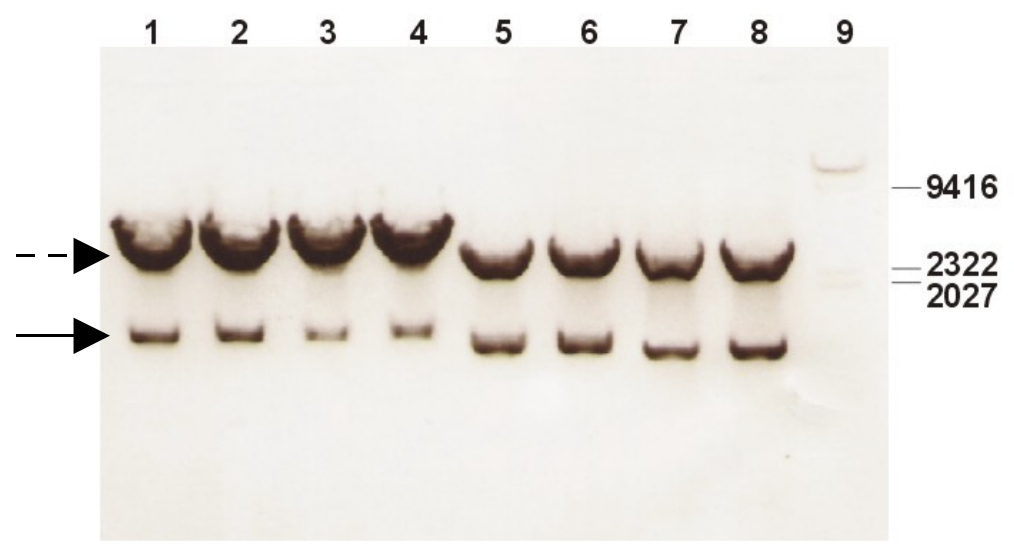

Fig. 9 - Digestão dos vetores pGEM-T-pspA3' e pGEM-T-pspA1' para obtenção dos fragmentos para construção intracelular: (canais 1 a 4) pspA3'; (canais 5 a 8) pspA1'; (canal 9) marcador molecular $\lambda /$ Hind III; A seta cheia indica as bandas do fragmento de $p \operatorname{sp} A$ '; A seta tracejada indica as bandas do vetor após retirada do inserto.

Os fragmentos $a b 1$ e $a b 3$ para a construção de expressão intracelular, também foram obtidos por digestão dos vetores pGEM-T-ab1 e pGEM-T-ab3 com enzima de restrição Nde I, e tratamento com a enzima Klenow para formar a extremidade abrupta ("blunt”). Após a purificação da primeira digestão, o produto foi digerido com a enzima $N s i$ I, obtendo fragmentos dos tamanhos esperados de aproximadamente $860 \mathrm{pb}$ para $a b 1$ e $980 \mathrm{pb}$ para $a b 3$, conforme mostra a figura 10 do gel de agarose $1 \%$.
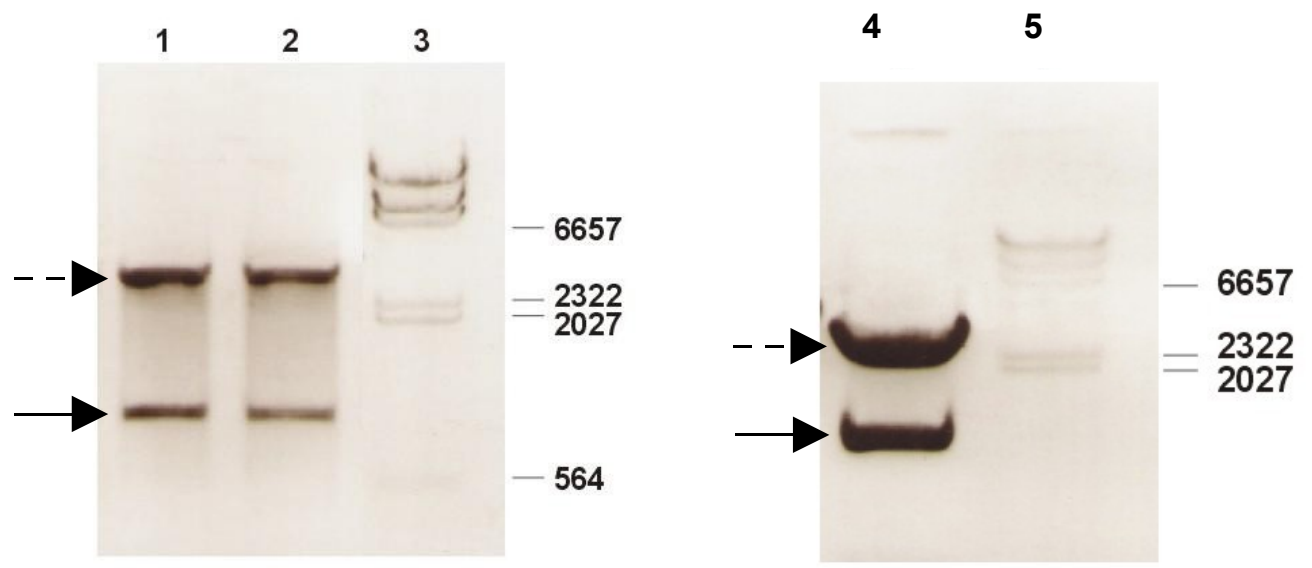

Fig. 10 - Digestão dos vetores pGEM-T-ab1 e pGEM-T-ab3 para construção intracelular: (canais 1 e 2) ab1; (canal 4) ab3; (canais 3 e 5) marcador molecular $\lambda / H i n d ~ I I I$; As setas cheias indicam as bandas dos fragmentos $a b$; As setas tracejadas indicam as bandas dos vetores após retirada do inserto.

Para a clonagem dos genes $p s p A 1$ ' e $p s p A 3$ ', visando a expressão da proteína ancorada à parede, o vetor pT1NXssANCH foi digerido nos sítios $N g o \mathrm{M}$ IV e $B a m \mathrm{H}$ I. A figura 11 mostra uma banda única do vetor do tamanho esperado de aproximadamente 6000pb. A digestão com a enzima $N g o \mathrm{M}$ IV forma uma extremidade compatível com a extremidade 
produzida pela digestão com a enzima $\operatorname{PinA} \mathrm{I}$, que foi utilizada como sítio de restrição à 5', dos genes de interesse quando estes foram amplificados. A enzima Bam $\mathrm{H}$ I foi utilizada para a extremidade 3' do vetor, pois forma extremidades compatíveis com as extremidades produzidas por BamH I e $B g l$ II na digestão dos genes de interesse.

Os genes $p s p A 1$ ' e $p s p A 3$ ' para a construção de expressão da proteína ancorada à parede, após confirmação por sequenciamento, foram obtidos por digestão dupla dos vetores pGEM-T-pspA1' e pGEM-T-pspA3'. Foram utilizadas as enzimas de restrição PinA I e BamH I para $p s p A 1$ ' e PinA I e Bgl II para $p s p A 3$ '. Conforme mostra a figura 11 do gel de agarose $1 \%$, obteve-se fragmentos dos tamanhos esperados de pspA1' (975pb) e pspA3' $(1050 \mathrm{pb})$ aproximadamente.

3

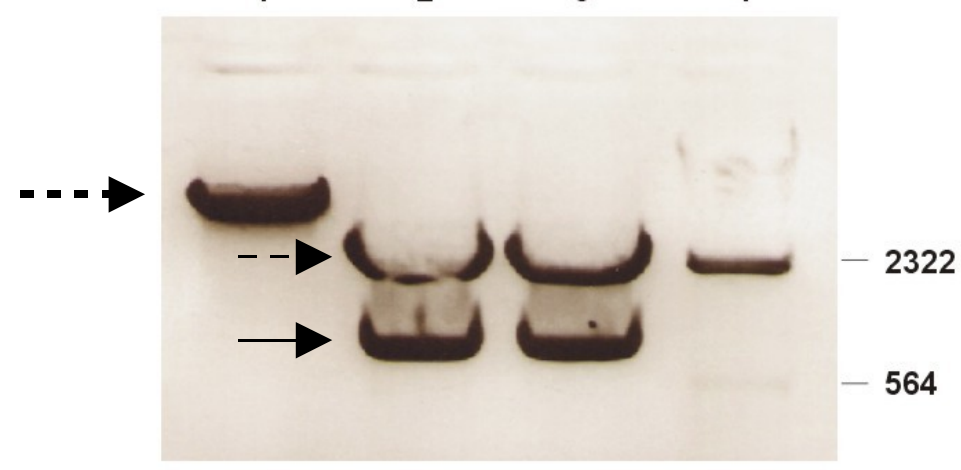

5

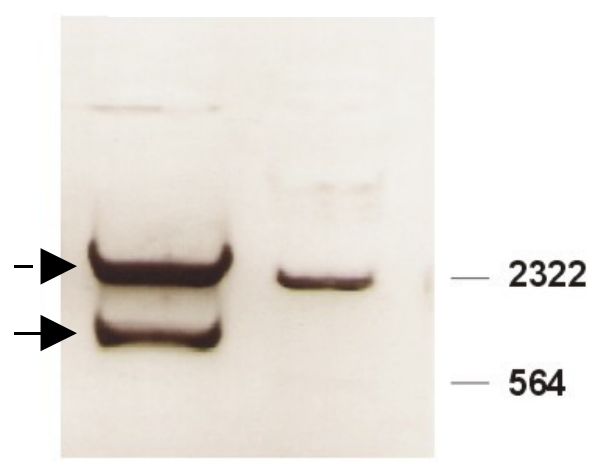

Fig. 11- Digestão dos vetores pGEM-T-pspA1' e pGEM-T-pspA3' para a construção de ancoramento das proteínas à parede: (canal 1) vetor pT1NXssANCH digerido com $N g o M$ IV e BamH I; (canais 2 e 3) pspA1'; (canal 5) pspA3'; (canais 4 e 6) marcador molecular $\lambda / H i n d$ III; As setas cheias indicam as bandas dos fragmentos de $p s p A$ '; As setas tracejadas indicam as bandas do vetor de clonagem após retirada do inserto; A seta pontilhada indica a banda do vetor de expressão linearizado.

\subsection{Transformação de Lactococcus lactis, Lactobacillus casei e Lactobacillus helveticus.}

Para L. lactis e L. casei, foram obtidas várias colônias isoladas, todas resistentes a eritromicina, de coloração branca com bordas definidas para L. lactis; e de coloração amarelada, estrelada, sem bordas definidas para L. casei. Já para L. helveticus, tentou-se transformar as construções intracelulares e as construções das proteínas ancoradas à parede celular, e após inúmeras tentativas, apenas os recombinantes expressando as proteínas intracelulares foram obtidos. Para esta bactéria, o protocolo de transformação não foi muito eficiente, pois poucos clones foram obtidos após vários dias de incubação, além de terem um crescimento muito lento mesmo em meio líquido. As colônias são opacas e sem bordas definidas. 


\subsection{Análise dos clones recombinantes de Lactococcus lactis por PCR}

Para a confirmação dos clones positivos, foram realizados PCRs utilizando $150 \mu \mathrm{L}$ de cultura crescida por $18 \mathrm{~h}$, e os oligonucleotídeos reversos específicos para cada gene. O oligonucleotídeo utilizado no sentido de leitura do gene foi o mesmo para todas as construções, pois ele se anela na região do promotor P1 do vetor. Neste protocolo, o DNA molde é o plasmídeo que está dentro da bactéria, sendo que esta sofre lise térmica no termociclador. A figura 12 mostra a amplificação específica dos genes de interesse inseridos no vetor pT1NX, e a obtenção de bandas dos tamanhos esperados de aproximadamente $975 \mathrm{pb}$ para $p s p A 1$ ' e 1050pb para $p s p A 3$ '. Como controle positivo da técnica utilizada, foi feita a mesma preparação para um clone de L. lactis portando também o vetor pT1NX, porém com o gene psaA (Oliveira et al., 2006 in press, vide Anexos). Neste caso o oligonucleotídeo reverso utilizado foi específico para $p s a A$.

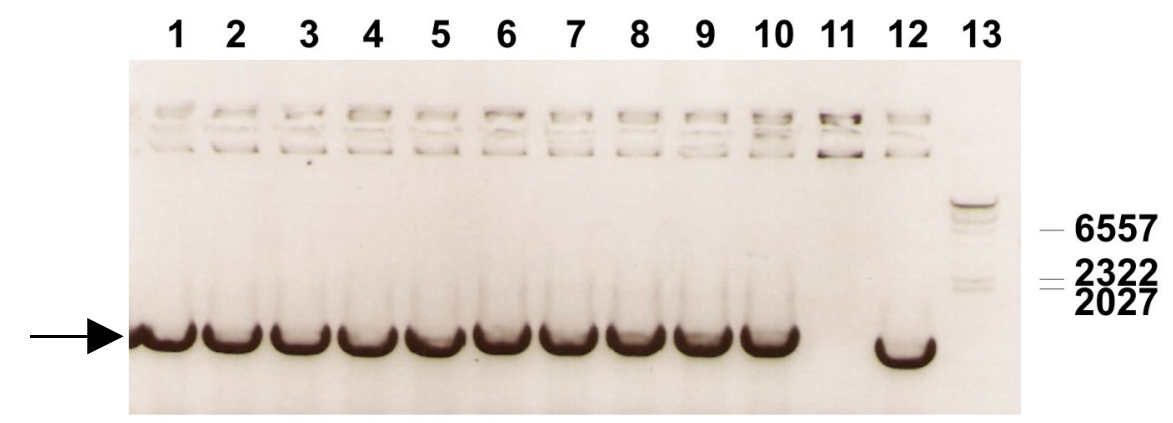

Fig. 12 - Análise por PCR das colônias resistentes de L. lactis para a construção intracelular: (canais 1 a 5) diferentes clones com vetor pT1NX-pspA1'; (canais 6 a 10) diferentes clones com vetor pT1NX-pspA3'; (canal 11) bactéria com vetor pT1NX - controle negativo do PCR; (canal 12) bactéria com vetor pT1NX-psaA - controle positivo do PCR; (canal 13) marcador molecular $\lambda /$ Hind III; A seta cheia indica as bandas específicas referentes às amplificações dos genes.

Clones de L. lactis positivos contendo os plasmídios pT1NX-ab1 ou pT1NX-ab3 podem ser observados nos resultados das PCRs mostrados na figura 13. Utilizando os oligonucleotídeos específicos, pode-se observar bandas únicas para cada reação nos tamanhos esperados de aproximadamente $860 \mathrm{pb}$ para $a b 1$ e de $980 \mathrm{pb}$ para $a b 3$. 

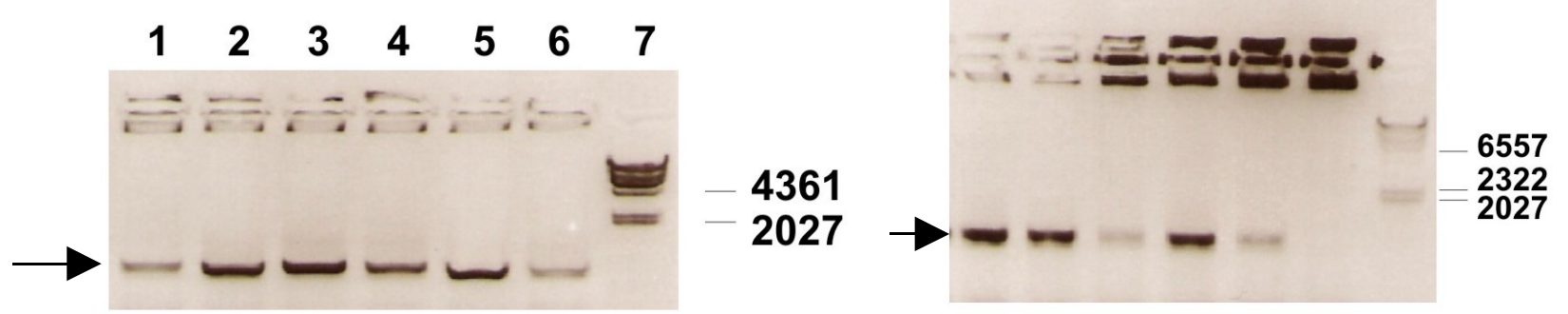

Fig. 13 - Análise por PCR das colônias resistentes de L. lactis para a construção intracelular: (canais 1 a 5) diferentes clones com vetor pT1NX-ab1; (canais 8 a 12) diferentes clones com vetor pT1NX-ab3; (canal 13) bactéria com vetor pT1NX - controle negativo do PCR; (canal 6) bactéria com vetor pT1NX-psaA - controle positivo do PCR; (canais 7 e 14) marcador molecular $\lambda /$ Hind III; As setas cheias indicam as bandas específicas referentes às amplificações dos genes.

Os clones de L. lactis recombinantes, obtidos após a transformação com os vetores de expressão das proteínas ancoradas à parede, também foram analisados por PCR com oligonucleotídeos específicos para os genes de interesse. A figura 14 mostra a amplificação de bandas específicas dos genes de interesse inseridos no vetor pT1NXssANCH. Obteve-se uma bandas dos tamanhos esperados de $975 \mathrm{pb}$ para $p s p A 1^{\prime}$ e de 1050pb para pspA3', aproximadamente.

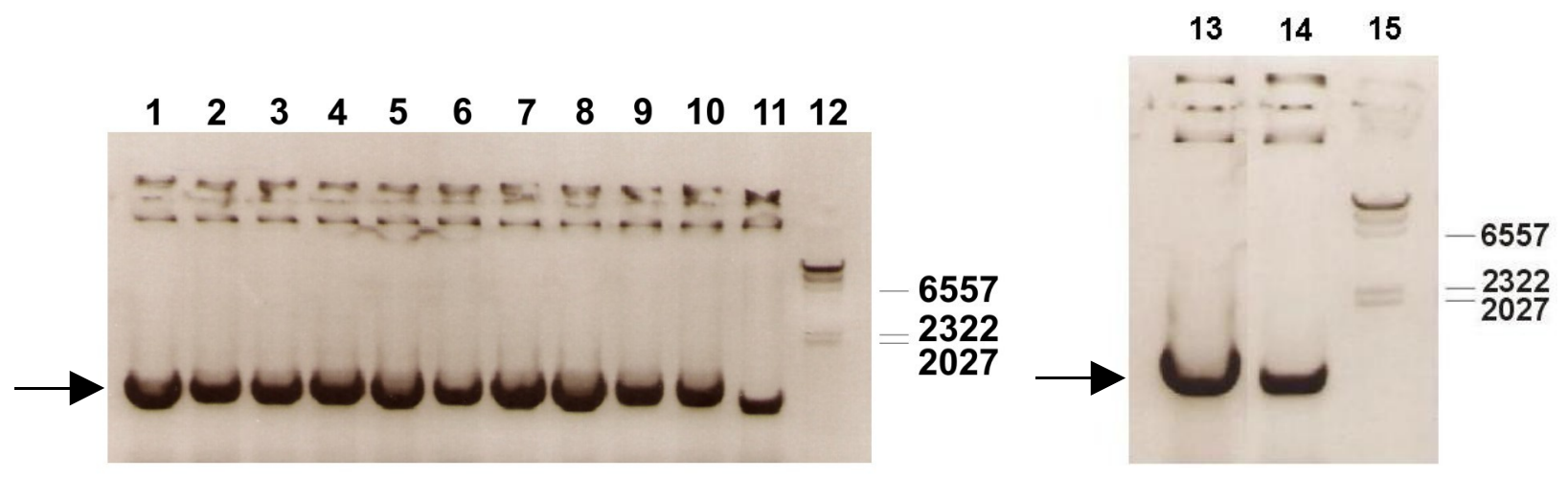

Fig. 14 - Análise por PCR das colônias resistentes de $L$. lactis para as construções de ancoramento à parede: (canais 1 a 10) diferentes clones com vetor pT1NXssANCH-pspA1'; (canal 13) clone com vetor pT1NXssANCH-pspA3'; (canais 11 e 14) bactéria com vetor pT1NX-psaA controle positivo do PCR; (canais 12 e 15) marcador molecular $\lambda /$ Hind III; As setas cheias indicam as bandas específicas referentes às amplificações dos genes. 


\subsection{Análise da expressão constitutiva das proteínas heterólogas em}

Lactococcus lactis, Lactobacillus casei, e Lactobacillus helveticus por Western-blot.

\section{Expressão intracelular}

Os DNAs plasmidiais dos clones recombinantes de L. lactis escolhidos para cada construção foram extraídos e purificados para a transformação de $L$. casei e $L$. helveticus. Alguns clones de L. lactis (LL), de L. casei (LC), e de L. helveticus (LH), obtidos após a transformação, foram analisados quanto à expressão das proteínas de interesse por Westernblot, e todos se mostraram positivos.

A figura 15 mostra a revelação da reação do anticorpo com as proteínas PspA1'e AB1, que estavam presentes nos lisados celulares. Cada canal do gel apresenta o lisado de um clone de cada bactéria transformada com os vetores pT1NX-pspA1'e pT1NX-ab1. Pode-se observar uma proteína de aproximadamente $50 \mathrm{kDa}$, tamanho esperado de PspA1', nos canais 2 (LLpT1NX-pspA1'), 4 (LC-pT1NX-pspA1') e 6 (LH-pT1NX-pspA1'). Nos canais 1 (LLpT1NX-ab1), 3 (LC-pT1NX-ab1) e 5 (LH-pT1NX-ab1) observa-se uma banda de 35kDa, tamanho esperado de AB1. Porém, além desta banda, ainda são observadas bandas minoritárias maiores, muito próximas às bandas majoritárias. Este padrão de bandas para PspA1' e AB1 foi visto para todos os clones analisados. Todas as bactérias recombinantes carregando os vetores vazios não apresentaram bandas reativas com o soro anti-PspA1' utilizado, visto em inúmeros ensaios (dados não mostrados).

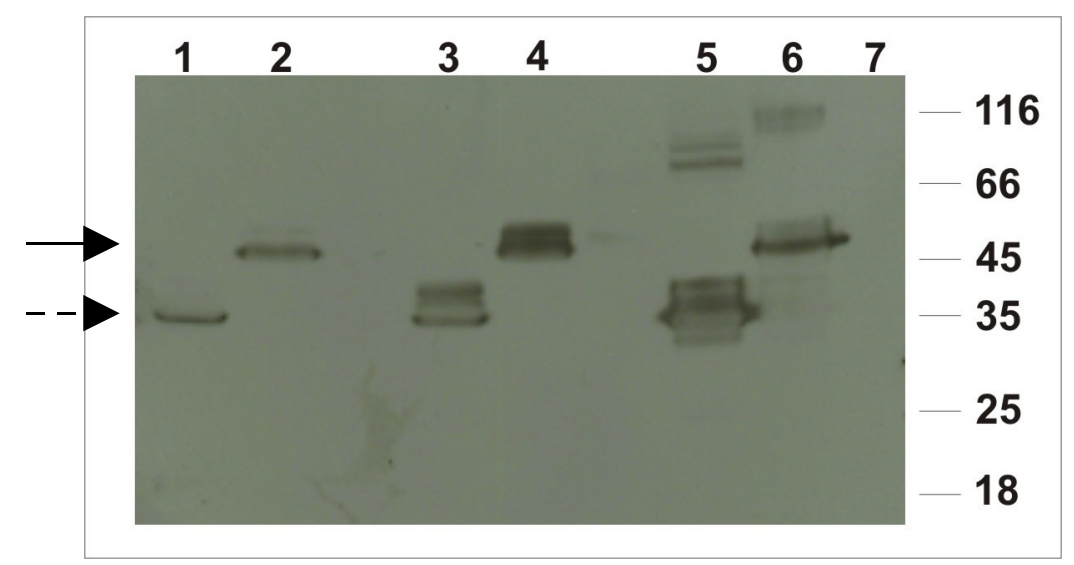

Fig. 15 - Expressão intracelular de AB1 e PspA1' em diferentes bactérias lácticas: (canais 1 e 2 ) $L$. lactis expressando AB1 e PspA1' respectivamente; (canais 3 e 4) L. casei expressando AB1 e PspA1' respectivamente; (canais 5 e 6) L. helveticus expressando AB1 e PspA1' respectivamente; (canal 7) marcador de massa molecular de proteínas; A seta cheia indica as bandas de PspA1'; A seta tracejada indica as bandas de AB1. 
Para PspA3' e AB3, também foram analisados vários clones de todas as bactérias. A figura 16 mostra o Western-blot dos lisados celulares de um clone representante de cada bactéria transformada com os vetores pT1NX-pspA3' e pT1NX-ab3. Observa-se a expressão de uma proteína de aproximadamente $50 \mathrm{kDa}$, tamanho esperado de PspA3', nos canais 2 (LLpT1NX-pspA3'), 4 (LC-pT1NX-pspA3') e 6 (LH-pT1NX-pspA3'). Nos canais 1 (LLpT1NX-ab3), 3 (LC-pT1NX-ab3) e 5 (LH-pT1NX-ab3) observa-se a expressão de uma proteína de 38kDa, tamanho esperado de AB3. Para PspA3' e AB3 foram observadas bandas únicas e específicas da proteína de interesse nos lisados das três bactérias lácticas utilizadas, diferentemente do padrão visto para PspA1' e AB1. Todas as bactérias recombinantes carregando os vetores vazios também não apresentaram bandas reativas com o soro antiPspA3' utilizado, visto em inúmeros ensaios (dados não mostrados), um exemplo pode ser visto no canal 1 da figura 32.

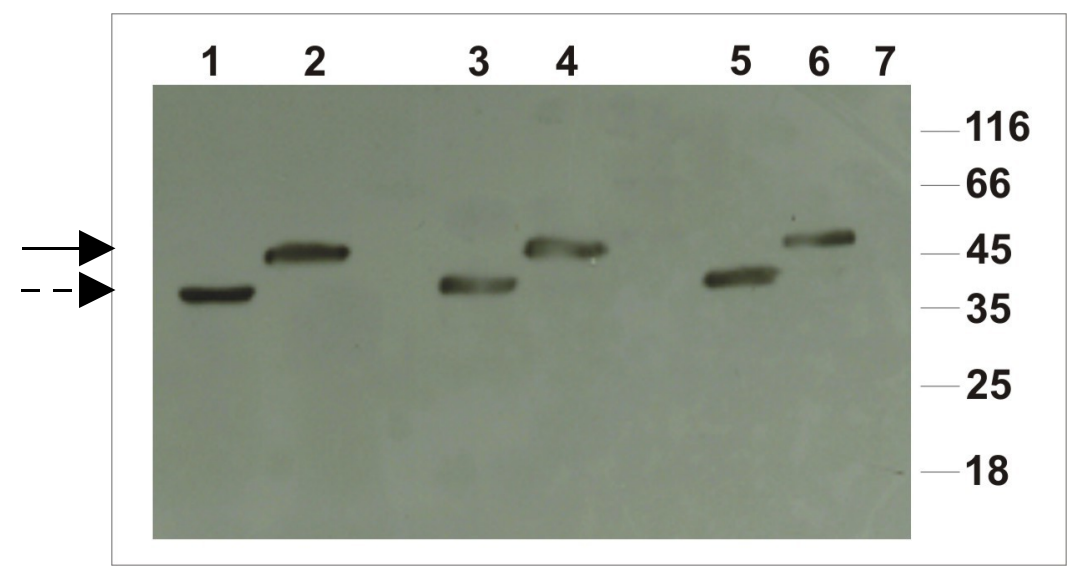

Fig. 16 - Expressão intracelular de AB3 e PspA3' em diferentes bactérias lácticas: (canais 1 e 2) $L$. lactis expressando AB3 e PspA3' respectivamente; (canais 3 e 4) $L$. casei expressando AB3 e PspA3' respectivamente; (canais 5 e 6) $L$. helveticus expressando AB3 e PspA3' respectivamente; (canal 7) marcador de massa molecular de proteínas; A seta cheia indica as bandas de PspA3'; A seta tracejada indica as bandas de AB3.

\section{Expressão de proteínas ancoradas à parede}

Foram analisados alguns clones resistentes de L. lactis, que foram positivos na análise por PCR, quanto à expressão da proteína ancorada à parede. Para isso, foi feito Western-blot dos lisados não centrifugados, para que os constituintes da parede celular estivessem presentes nas amostras aplicadas no SDS-PAGE. A figura 17 mostra a análise de dois clones transformados com o vetor pT1NXssANCH-pspA1', que apresentaram bandas muito próximas na altura do tamanho esperado de $70 \mathrm{kDa}$, que corresponde a proteína PspA1' mais o peptídeo de ancoramento presente no vetor. Estas bandas sugerem que a proteína pode estar 
sofrendo processamento do peptídeo sinal, como esperado para este caso, já que a sua seqüência foi mantida inteira nesta construção, para que a proteína fosse direcionada para a parede celular. Abaixo desta, observa-se uma banda de menor intensidade (seta tracejada) que pode indicar a degradação da proteína.

Para PspA3', o único clone resistente obtido de L. lactis transformado com o vetor pT1NXssANCH-pspA3', que foi positivo por PCR, também foi analisado quanto à expressão da proteína de interesse na parede celular, por Western-blot. A figura 17 mostra uma banda única e específica referente à expressão da proteína PspA3' mais o peptídeo de ancoramento, que corresponde com o tamanho esperado de $70 \mathrm{kDa}$.
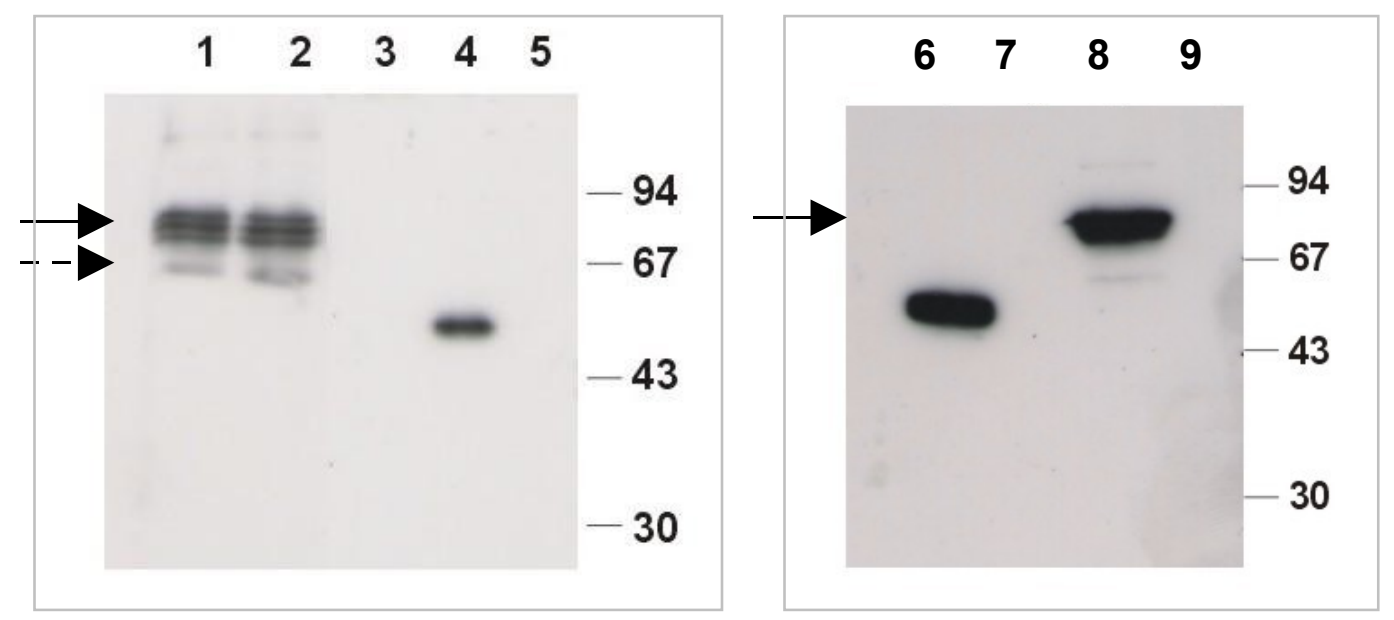

Fig. 17 - Expressão de PspA1' e PspA3' na parede celular de L. lactis: (canais 1 e 2) diferentes clones com vetor pT1NXssANCH-pspA1'; (canal 8) clone com vetor pT1NXssANCH-pspA3'; (canal 3 e 7) bactéria com vetor pT1NXssANCH - controle negativo do Western-blot; (canal 4 e 6) lisado de L. lactis expressando PspA1' e PspA3' intracelular, respectivamente - controle positivo do Western-blot; (canal 5 e 9) marcador de massa molecular de proteínas; As setas cheias indicam as bandas das proteínas de interesse; A seta tracejada indica possível degradação da proteína.

Um clone positivo no PCR de L. lactis, de cada uma das duas construções de ancoramento das proteínas heterólogas na parede, foi escolhido para preparação dos plasmídios, que foram utilizados para transformar L. casei. A figura 18 mostra a análise de alguns clones de L. casei resistentes a eritromicina após transformação, que foram escolhidos aleatoriamente, para verificação da expressão das proteínas de interesse. Todos os lisados apresentaram bandas de massa molecular correspondente ao tamanho esperado de $70 \mathrm{kDa}$, referente às proteínas PspA1' ou PspA3' com o peptídeo de ancoramento. Além disso, os clones de L. casei apresentaram bandas do tamanho de PspA1' ou PspA3' (50kDa), indicando que houve processamento de parte das proteínas e provável retirada da seqüência de 
ancoramento. Nestes Western-blots também são visualizadas bandas de degradação das proteínas não processada.
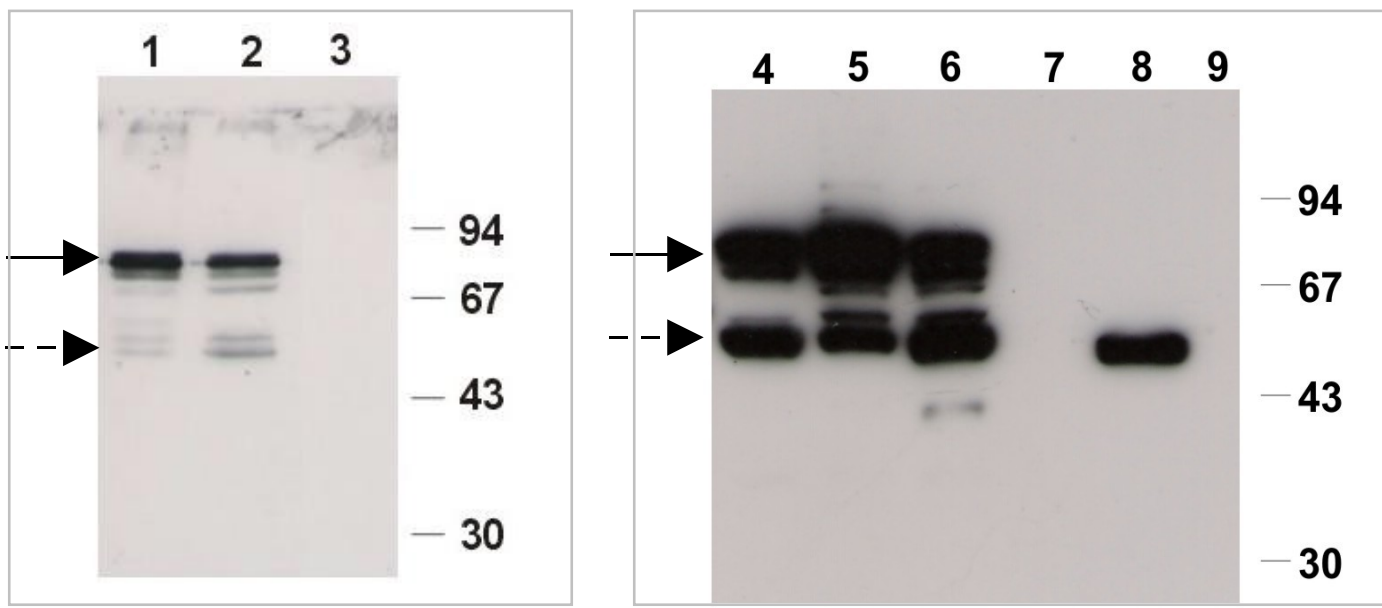

Fig. 18 - Expressão de PspA1' e PspA3' na parede celular de L. casei: (canais 1 e 2) diferentes clones com vetor pT1NXssANCH-pspA1'; (canais 4, 5 e 6) diferentes clones com vetor pT1NXssANCH-pspA3'; (canal 7) bactéria com vetor pT1NXssANCH - controle negativo do Western-blot; (canal 8) lisado de L. casei expressando PspA3' intracelular - controle positivo do Western-blot; (canais 3 e 9) marcador de massa molecular de proteínas; As setas cheias indicam as bandas específicas das proteínas PspA1' ou PspA3' fusionadas ao peptídeo de ancoramento; As setas tracejadas indicam as bandas das proteínas processadas sem 0 peptídeo de ancoramento.

\section{Análise do sobrenadante do meio de cultura}

Os sobrenadantes dos meios de cultura de L. lactis, L. casei e L. helveticus, referentes a todas as construções intracelulares e de ancoramento à parede, foram analisados para confirmação da ausência de secreção das proteínas de interesse. Para isso, foi crescido um clone de cada construção para cada bactéria, e após centrifugação, o meio de cultura foi coletado e concentrado para análise por Western-blot.

Os meios de cultura dos clones de L. lactis transformados com os vetores pT1NXpspA1', pT1NX-ab1, pT1NX-pspA3' e pT1NX-ab3, foram analisados como mostra a figura 19, após crescimento em meio líquido até $\mathrm{DO}_{600}$ de 1,5. Estes clones transformados com as construções intracelulares apresentaram pouca quantidade das proteínas no meio de cultura. As bandas que aparecem no Western-blot correspondem ao tamanho esperado de aproximadamente 50kDa para PspA1' (canal 3A) e PspA3' (canal 3B), de 35kDa para AB1 (canal 2A) e 38kDa para AB3 (canal 2B). A presença destas proteínas no meio de cultura pode corresponder a um pouco de lise celular durante o crescimento, ou algum tipo de escape intracelular. Como controle positivo do Western-blot, foram aplicados os extratos celulares 
dos mesmos clones (canais 4A e B referente $\mathrm{AB} 1$ e $\mathrm{AB} 3$, respectivamente; canais $5 \mathrm{~A}$ e $\mathrm{B}$ referente PspA1' e PspA3', respectivamente).

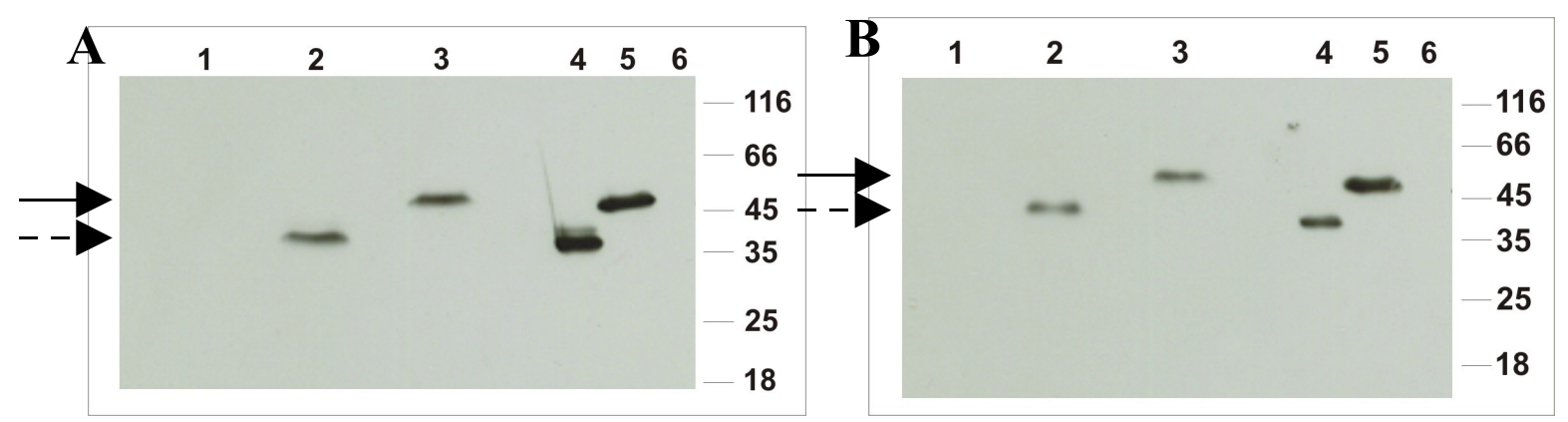

Fig. 19 - Análise dos meios de cultura de $L$. lactis transformados com as construções intracelulares: (canais 1A e B) pT1NX; (canais 2) pT1NX-ab1 (A) e pT1NX-ab3 (B); (canais 3) pT1NXpspA1' (A) e pT1NX-pspA3' (B); (canais 4) lisados dos clones com vetor pT1NX-ab1 (A) e pT1NX-ab3 (B); (canais 5) lisados dos clones com vetor pT1NX-pspA1' (A) e pT1NX-pspA3' (B); (canais 6A e B) marcador de massa molecular de proteínas; As setas cheias indicam as bandas específicas das proteínas PspA1' (A) e PspA3' (B); As setas tracejadas indicam as bandas das proteínas AB1 (A) e AB3 (B).

Os sobrenadantes de cultura das bactérias portando as construções de ancoramento foram analisados para possível secreção da proteína de interesse. Para isso, foram crescidos os clones de L. lactis, portando os vetores pT1NXssANCH-pspA1' e pT1NXssANCH-pspA3', em meio líquido até $\mathrm{DO}_{600}$ de 1,5. Após o preparo do sobrenadante, o que se observou no Western-blot, como mostra a figura 20, foi uma pequena quantidade da proteína PspA1' e PspA3' no meio de cultura. As bandas eram do tamanho esperado de aproximadamente $50 \mathrm{kDa}$, correspondentes às proteínas sem o peptídeo de ancoramento. Portanto, pode-se inferir que a quantidade de proteína vista refere-se a um pouco de lise celular durante o crescimento, ou ainda à instabilidade e portanto quebra do peptídeo de ancoramento liberando a proteína na forma processada.

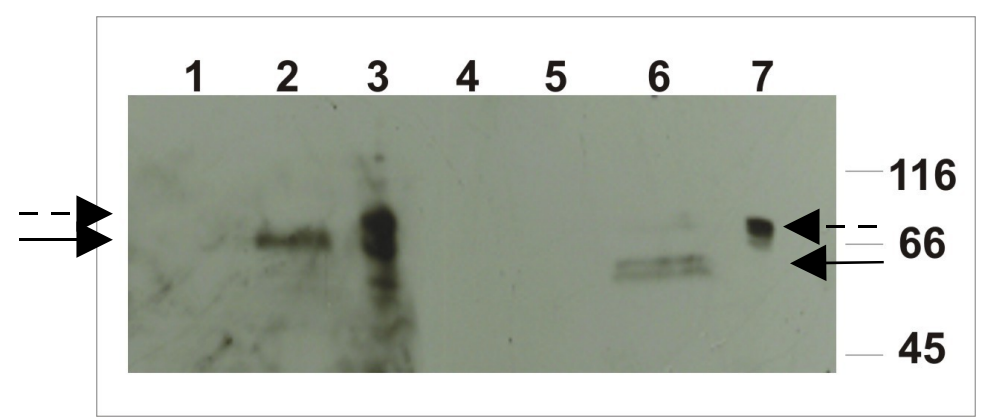

Fig. 20 - Análise do meio de cultura de L. lactis transformados com as construções das proteínas ancoradas à parede celular: (canal 1) pT1NXssAnch; (canal 2) pT1NXssAnch-pspA1'; (canal 3) lisado do clone com vetor pT1NXssAnch-pspA1'; (canal 4) marcador de massa molecular de proteínas; (canal 5) pT1NxssAnch; (canal 6) pT1NXssAnch-pspA3'; (canal 7) lisado do clone com vetor pT1NXssAnch-pspA3'; As setas cheias indicam as bandas específicas das proteínas processadas; As setas tracejadas indicam as bandas das proteínas não processadas. 
Os meios de cultura dos clones de L. casei também foram analisado por Western-blot. Para isso, após o crescimento dos clones escolhidos até aproximadamente $\mathrm{DO}_{550}$ de 1,6 e posterior centrifugação, os sobrenadantes dos meios de cultura foram coletados e concentrados para análise. A figura 21 mostra que os clones com as construções intracelulares pT1NX-pspA1' (canal 3), pT1NX-pspA3' (canal 7), pT1NX-ab1 (canal 2) e pT1NX-ab3 (canal 6) apresentaram pouca quantidade da proteína no meio de cultura, com os tamanhos esperados de aproximadamente 50kDa para PspA1' e PspA3', de 35kDa para AB1 e 38kDa para AB3. É possível sugerir também, assim como para L. lactis, que a presença destas proteínas nos meios de cultura podem corresponder a um pouco de lise celular durante o crescimento, ou algum tipo de escape intracelular, já que estas construções não possuem seqüência sinal para sinalização de secreção.
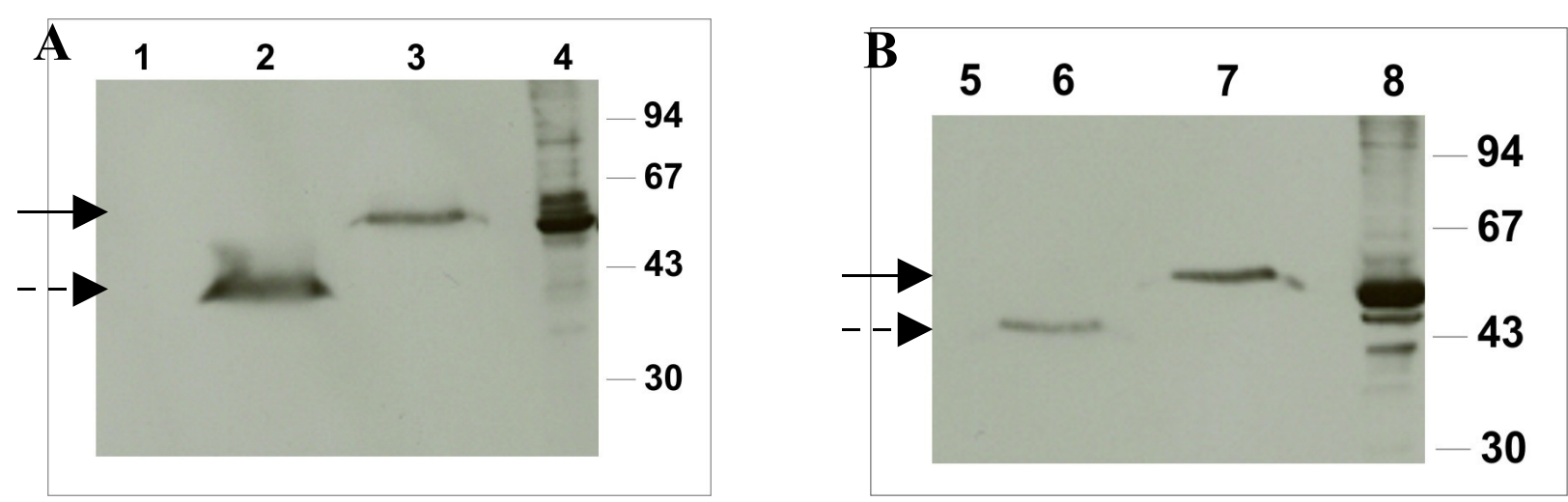

Fig. 21 - Análise dos meios de cultura de $L$. casei transformados com as construções intracelulares: (canais 1 e 5) marcador de massa molecular de proteínas; (canais 2 e 6) pT1NX-ab1' e pT1NX-ab3', respectivamente; (canais 3 e 7) pT1NX-pspA1' e pT1NX-pspA3', respectivamente; (canais 4 e 8) lisados dos clones com vetor pT1NX-pspA1' e pT1NX-pspA3', respectivamente; As setas cheias indicam as bandas específicas das proteínas PspA1' (A) e PspA3' (B); As setas tracejadas indicam as bandas das proteínas AB1 (A) e AB3 (B).

Os clones de L. casei, portando as construções de ancoramento das proteínas de interesse na parede celular, também foram analisados por Western-blot. Para isso, após crescimento e centrifugação dos clones escolhidos, os sobrenadantes dos meios de cultura foram coletados e concentrados para análise. A figura 22 mostra que os clones com as construções pT1NXssAnch-pspA1' e pT1NXssAnch-pspA3' não estão secretando as proteínas PspA1' e PspA3', respectivamente, pois a pouca quantidade das proteínas vista no sobrenadante dos meios de cultura está na forma não processada, o que provavelmente corresponde à lise de bactérias durante o crescimento que liberaram um pouco das proteínas para o meio extracelular. 

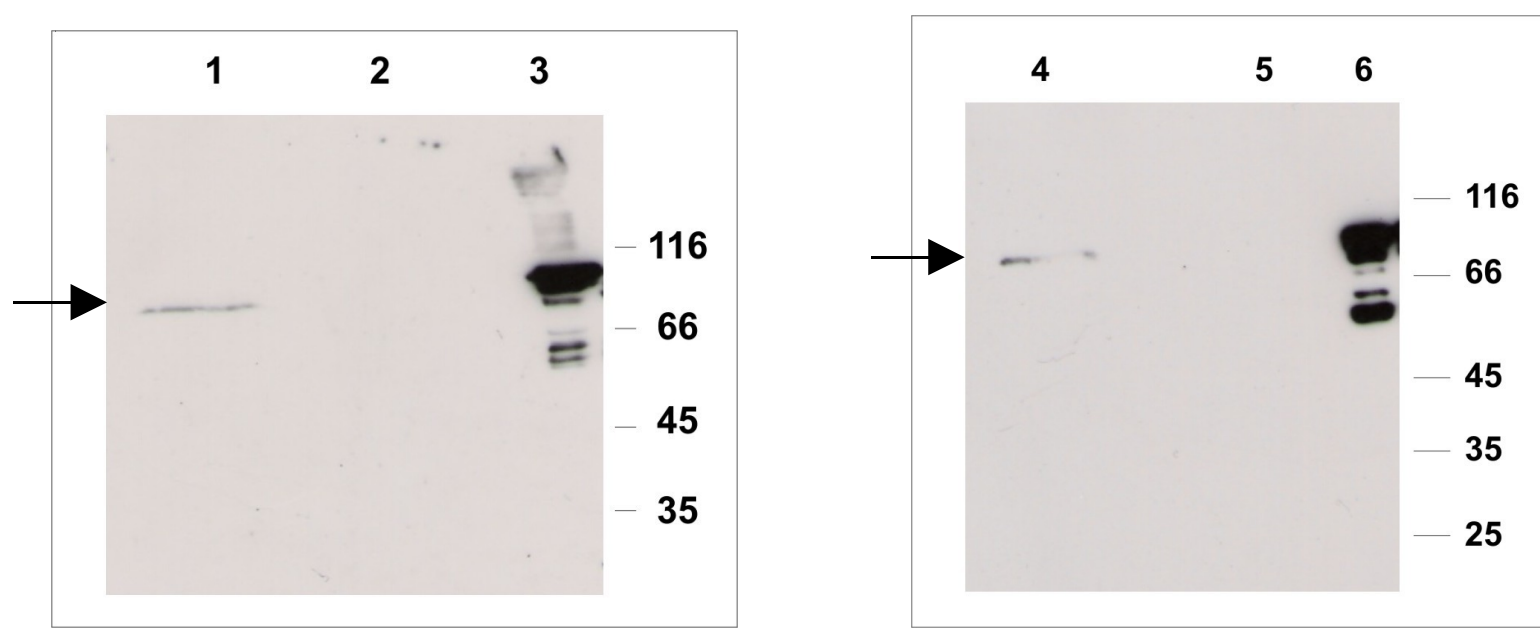

Fig. 22 - Análise dos meios de cultura de $L$. casei transformados com as construções das proteínas ancoradas à parede celular: (canais 1 e 4) pT1NXssANCH-pspA1' e pT1NXssANCH-pspA3', respectivamente; (canais 2 e 5) marcador de massa molecular de proteínas; (canais 3 e 6) lisados dos clones com vetor pT1NXssANCH-pspA1' e pT1NXssANCH-pspA3', respectivamente - controle positivo do Western-blot; As setas cheias indicam as bandas específicas das proteínas com peptídeo de ancoramento.

Para L. helveticus, também foram analisados os meios de cultura dos clones escolhidos. A partir de culturas crescidas até aproximadamente $\mathrm{DO}_{660} 1,3$, centrifugou-se e coletou-se o sobrenadante, para posterior concentração das amostras e análise por Westernblot. A figura 23 mostra a presença de um pouco das proteínas PspA1' e AB1 no meio de cultura, para os clones transformados com os vetores pT1NX-pspA1' (canal 3A) e pT1NXAB1 (canal 2A), respectivamente. Visto que a quantidade das proteínas nos meios de cultura é bem menor do que a vista nos respectivos lisados, provavelmente, isto corresponde a um pouco de lise celular, como visto para as outras bactérias. A figura 23 mostra também a ausência das proteínas AB3 (canal 2B) e PspA3' (canal 3B) nos meios de cultura.
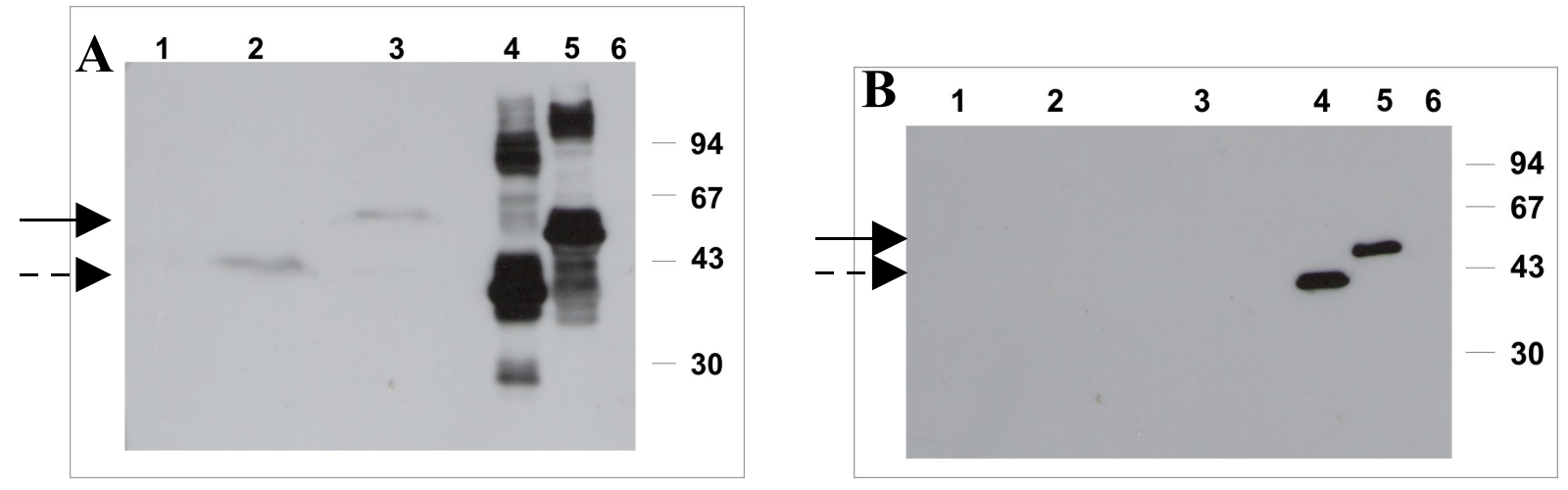

Fig. 23 - Análise dos meios de cultura de L. helveticus transformados com as construções intracelulares: (canais 1A e B) pT1NX; (canais 2) pT1NX-ab1 (A) e pT1NX-ab3 (B); (canais 3) pT1NXpspA1' (A) e pT1NX-pspA3' (B); (canais 4) lisados dos clones com vetor pT1NX-ab1 (A) e pT1NX-ab3 (B); (canais 5) lisados dos clones com vetor pT1NX-pspA1' (A) e pT1NX-pspA3' (B); (canais 6A e B) marcador de massa molecular de proteínas; As setas cheias indicam as bandas específicas das proteínas PspA1' (A) e PspA3' (B); As setas tracejadas indicam as bandas das proteínas AB1 (A) e AB3 (B). 


\subsection{Análise da exposição da proteína heteróloga nas bactérias lácticas íntegras.}

A fim de confirmar a exposição das proteínas de interesse ancoradas à parede celular, um clone de L. lactis e L. casei de cada construção (intracelular e ancorado à parede) foi crescido até atingir DO entre 1,5 e 1,7 (600nm para L. lactis e 550nm para L. casei), centrifugado e incubado com anticorpos específicos (conforme descrito no item 3.11 dos Materiais e Métodos). Os clones transformados com as construções intracelulares também foram testados, para a confirmação de que a proteína heteróloga está apenas no meio intracelular. Além destes, os clones que carregam o vetor vazio foram utilizados como controles negativos. Os resultados mostram que apenas as bactérias lácticas transformadas com as construções de ancoramento à parede celular, tanto para PspA1' quanto para PspA3', apresentaram as proteínas de interesse expostas, tanto para L. lactis (fig 24) como para $L$. casei (fig 25). As bactérias transformadas com os outros vetores (intracelular e vetor sem o gene de interesse) apresentaram apenas reações basais. Durante este experimento os anticorpos específicos reagiram apenas com as proteínas de interesse expostas, ou seja, que foram dirigidas para à parede celular, mostrando que as bactérias permaneceram íntegras, não havendo portanto acesso dos anticorpos às proteínas intracelulares.

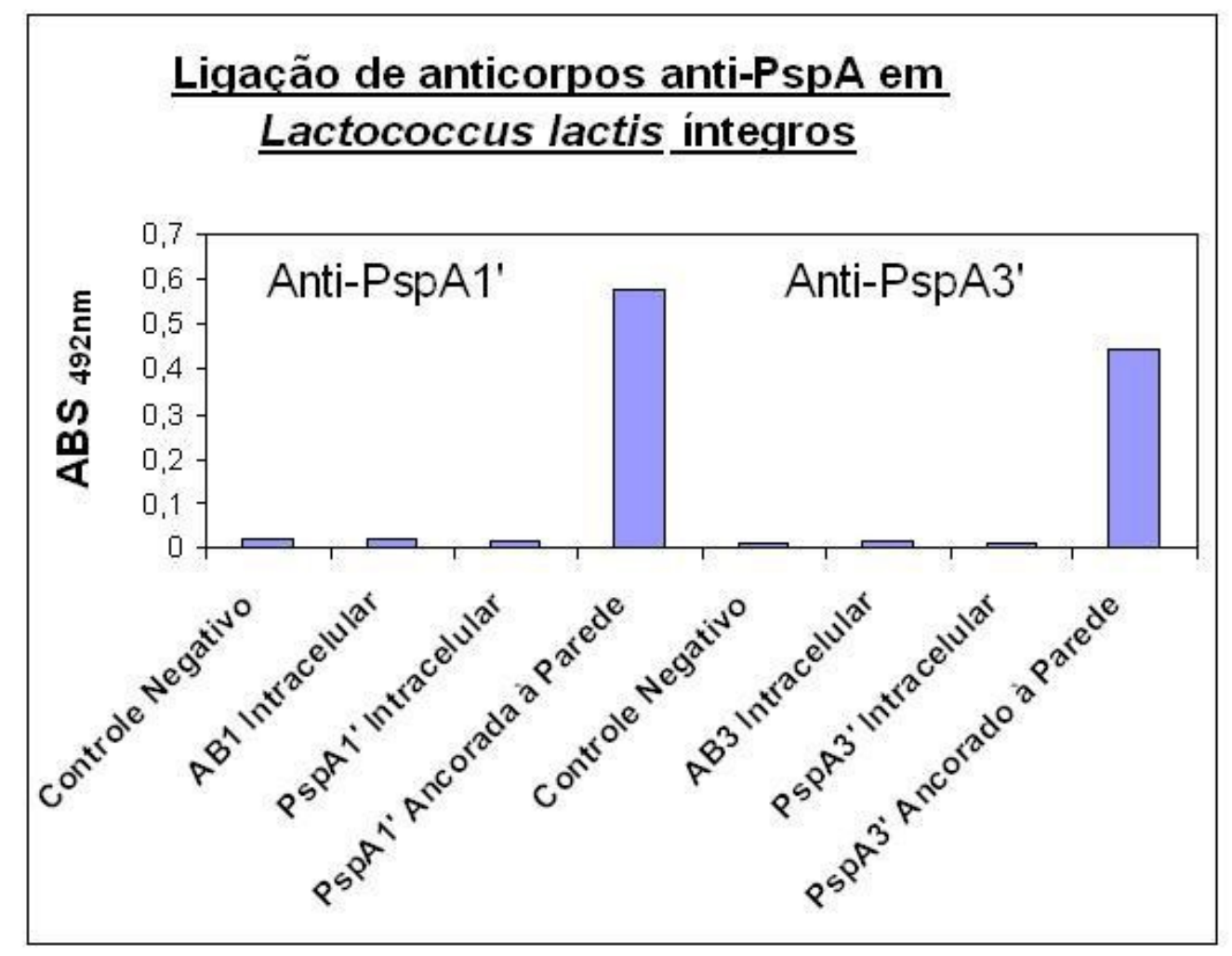

Fig 24 - Análise da exposição das proteínas de interesse em $L$. lactis recombinantes. 


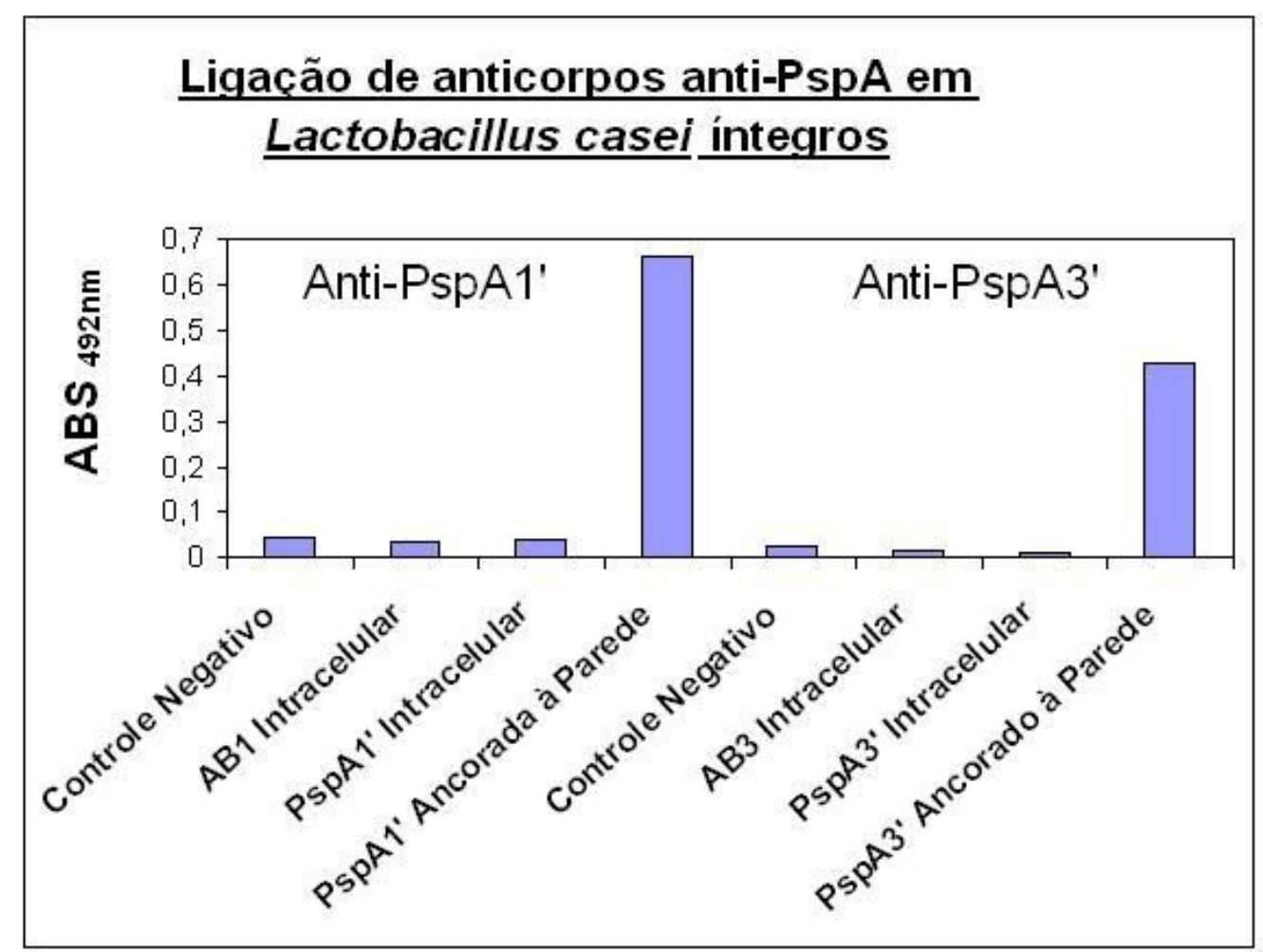

Fig 25 - Análise da exposição das proteínas de interesse em $L$. casei recombinantes.

\subsection{Curva de crescimento das bactérias recombinantes}

Para algumas das bactérias expressando as proteínas de interesse, foram feitas curvas de crescimento. Com estes dados foi possível visualizar as diferentes fases de crescimento de cada bactéria. Sendo que estas fases variam de acordo com as bactérias lácticas estudadas. Com as diluições seriadas da cultura em diferentes DOs, foi possível estimar aproximadamente a quantidade de bactéria encontrada em uma dada DO.

Para L. lactis, foram feitas as curvas de crescimento dos clones expressando PspA1' ou PspA3' no meio intracelular ou ancorada à parede. Todos foram crescidos nas mesmas condições, e ao mesmo tempo. Na figura 26, é possível visualizar o gráfico das DOs em relação ao tempo. Pode-se constatar que todas as bactérias estudadas apresentaram aproximadamente o mesmo padrão de crescimento. Sendo que, em DO 1,0 elas se encontram em fase logarítmica, enquanto que em DO 1,5 elas já se encontram em fase estacionária, e não ultrapassam esta DO. E para atingir esta fase estacionária, as bactérias levaram cerca de 8 horas. 


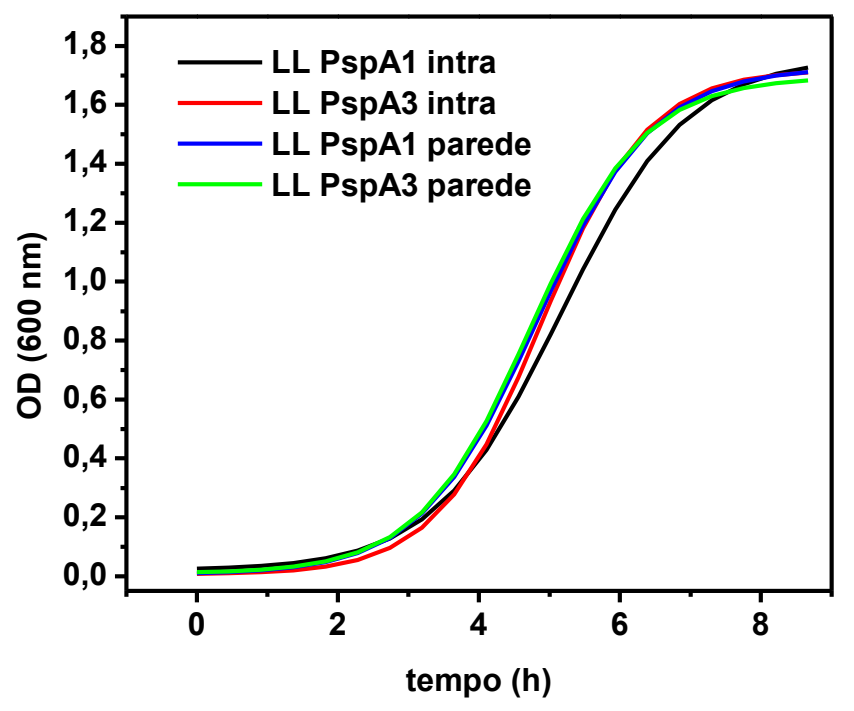

Fig 26 - Curvas de crescimento de $L$. lactis recombinantes.

Para L. casei, foram feitas curvas de crescimento dos clones expressando PspA1' no meio intracelular e ancorada à parede, além do clone com vetor pT1NX. Todos foram crescidos nas mesmas condições, e ao mesmo tempo. Na figura 27, é possível visualizar que todas as bactérias estudadas apresentaram aproximadamente o mesmo padrão de crescimento. Sendo que, em DO 1,5 elas se encontram quase em final da fase logarítmica, enquanto que em DO 2,0 elas se encontram em início de fase estacionária, e não ultrapassam a DO de 2,3. Para atingir esta fase estacionária, as bactérias levaram quase 15 horas.

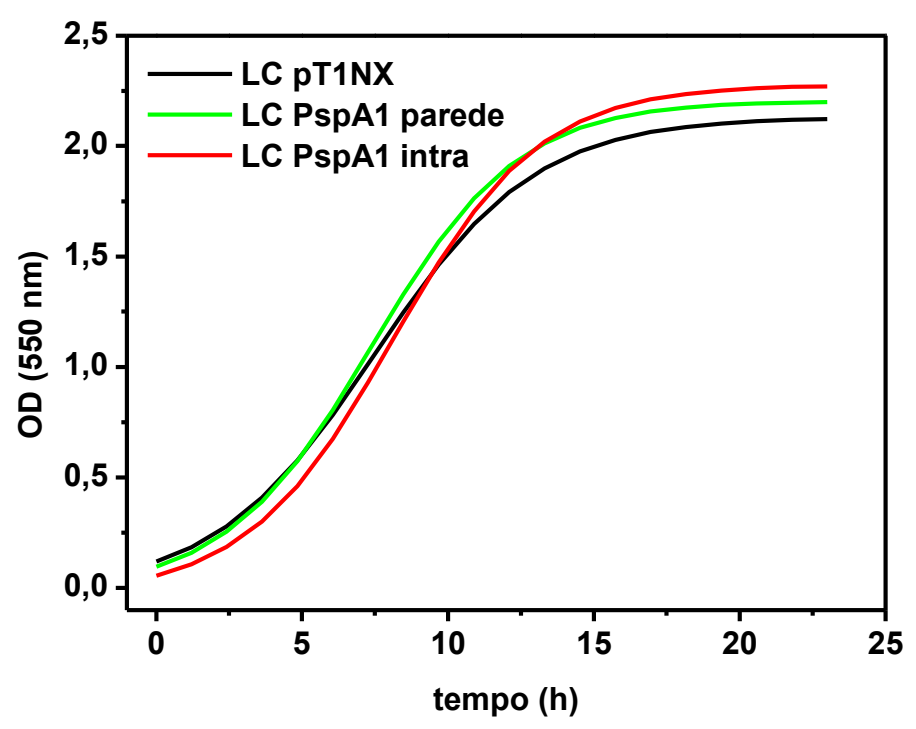

Fig 27 - Curva de crescimento de $L$. casei recombinantes. 
Para L.helveticus, foram feitas curvas de crescimento do clone expressando PspA1' no meio intracelular, e do clone com vetor pT1NX. Os dois clones foram crescidos nas mesmas condições, e ao mesmo tempo. Na figura 28, é possível visualizar que as bactérias estudadas apresentaram aproximadamente o mesmo padrão de crescimento. Sendo que, em DO 1,0 elas se encontram em fase logarítmica, porém em DO 1,5 elas já se encontram em fase estacionária, e não ultrapassam a DO de 1,6. Como foi possível constatar, L.helveticus tem um crescimento muito lento, quando comparado com as demais bactérias lácticas estudadas. Sendo que, a fase estacionária só foi atingida após 30 horas de crescimento. Outra observação, é que nas mesmas DOs das outras bactérias, os L. helveticus recombinantes possuem uma quantidade menor de bactérias, como pode ser comparado nos gráficos das figuras 29, 30 e 31, o que dificulta a obtenção de $10^{9} \mathrm{CFU}$, que é a quantidade utilizada comumente para imunização com bactérias lácticas (Seegers, 2002).

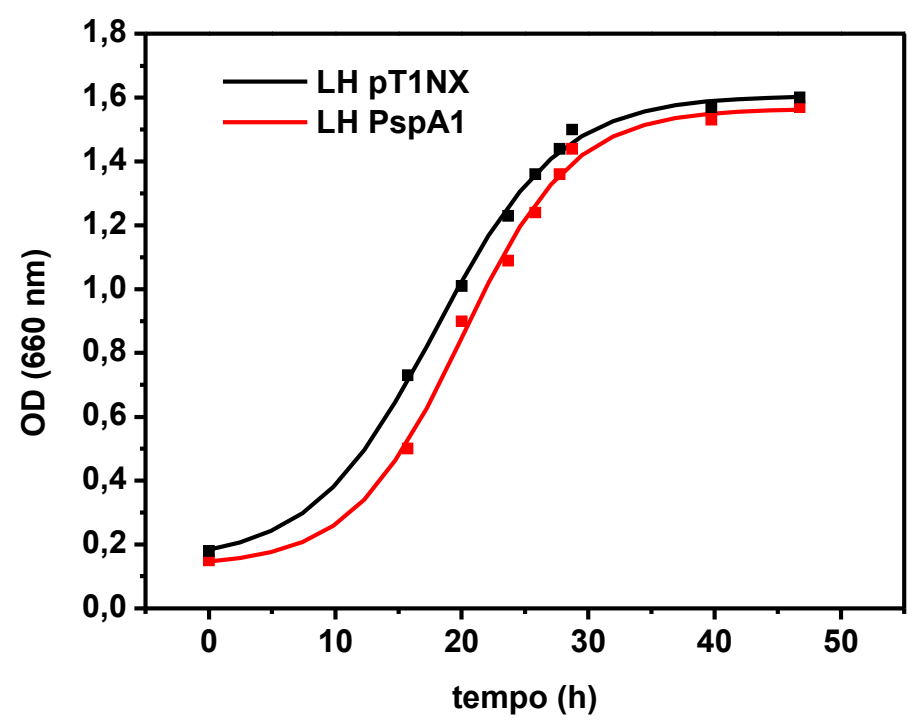

Fig 28 - Curva de crescimento de $L$. helveticus recombinantes.

Para contagem das CFUs de cada bactéria utilizada, foram aliquotados $10 \mu \mathrm{L}$ das culturas em diferentes DOs durante a realização das curvas de crescimento. Com este volume, foram feitas diluições seriadas de 1:10, e plaqueadas nos respectivos meios-ágar para cada bactéria. A figura 29 mostra as quantidades de L. lactis obtidas em $10 \mu \mathrm{L}$ de cultura, nas DOs testadas. Nesta figura, pode-se observar uma grande quantidade de bactéria por $\mu \mathrm{L}$, muito maior que para as outras bactérias (vide figuras 30 e 31). Várias repetições foram realizadas e os números obtidos foram sempre da mesma ordem de grandeza. 


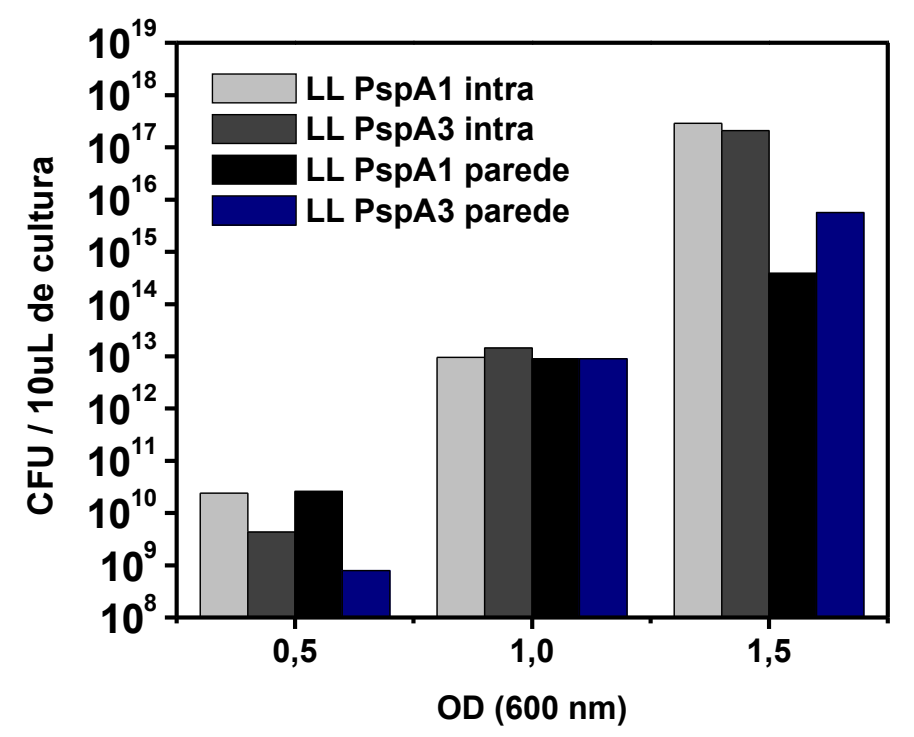

Figura 29 - Diluições seriadas de $L$. lactis recombinantes em diferentes DOs.

A figura 30 mostra as quantidades de L. casei obtidas em $10 \mu \mathrm{L}$ de cultura, nas diferentes DOs testadas. É possível observar que a DO ideal para obtenção de $10^{9}$ bactérias, quantidade que a maioria dos trabalhos utilizam para imunização com bactérias lácticas recombinantes, foi 1,5. Nos resultados preliminares de imunização descritos nesta dissertação, vide item 4.10, utilizou-se $10^{8}$ bactérias obtidas em DO 2,3. Isto provavelmente se deve ao longo tempo de crescimento dos L. casei utilizados (cerca de $20 \mathrm{~h}$ de cultivo), sugerindo que houve morte celular.

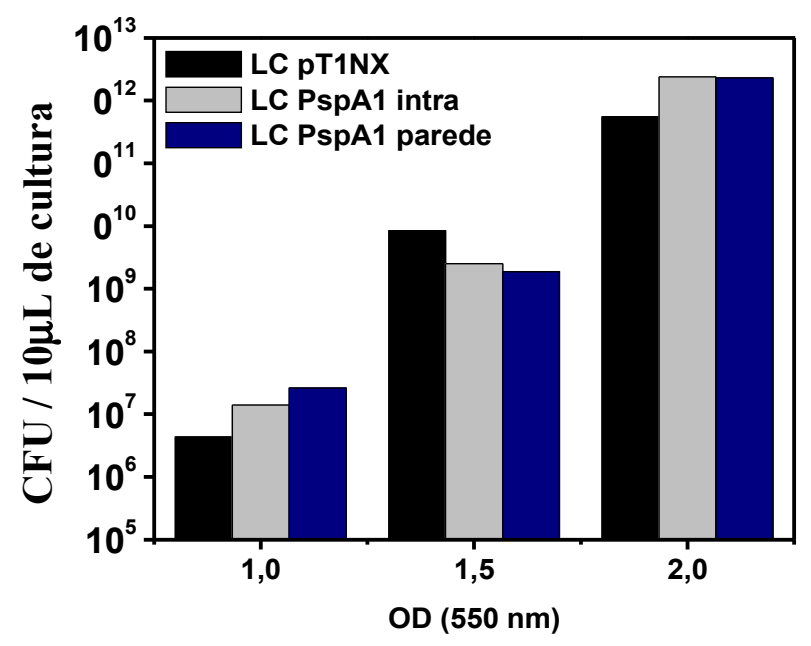

Figura 30 - Diluições seriadas de $L$. casei recombinantes em diferentes DOs. 
A figura 31 mostra as médias das quantidades de L. helveticus obtidas em $10 \mu \mathrm{L}$ de cultura, nas diferentes DOs testadas. Como já foi mencionado, observa-se um número menor de bactérias por $\mu \mathrm{L}$ quando comparado às outras bactérias, o que dificulta a obtenção de $10^{9}$ CFU.

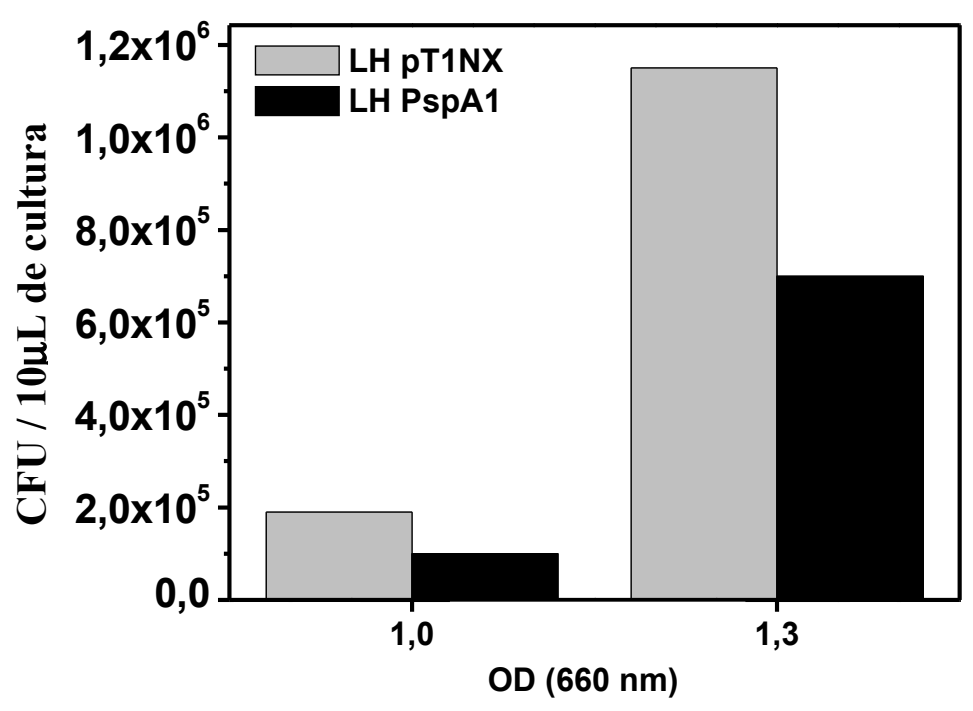

Figura 31 - Diluições seriadas de $L$. helveticus recombinantes em diferentes DOs.

\subsection{Quantificação de PspA produzida pelas bactérias recombinantes}

As bactérias expressando as proteínas heterólogas foram avaliadas quanto à quantidade de proteínas produzidas. Para isso, as diferentes bactérias utilizadas, portando as diferentes construções realizadas, foram crescidas até uma DO de aproximadamente 1,5. Depois da centrifugação, e da lise, realizou-se Western-blots dos lisados, que correspondiam a quantidades conhecidas de bactérias (de $10^{7}$ a $10^{9}$, dependendo do clone - vide tabela 1). Estes lisados foram aplicados ao lado de diferentes concentrações das proteínas recombinantes purificadas de E. coli. Com base nestas curvas de concentração, foram feitas estimativas das quantidades das proteínas presentes por número de célula das bactérias recombinantes. Um exemplo é mostrado na figura 32, onde as quantidades das proteínas AB3 e PspA3' produzidas por L. helveticus foram determinadas. Com base em géis como exemplificado na figura 32 , gerou-se a tabela 1 . 


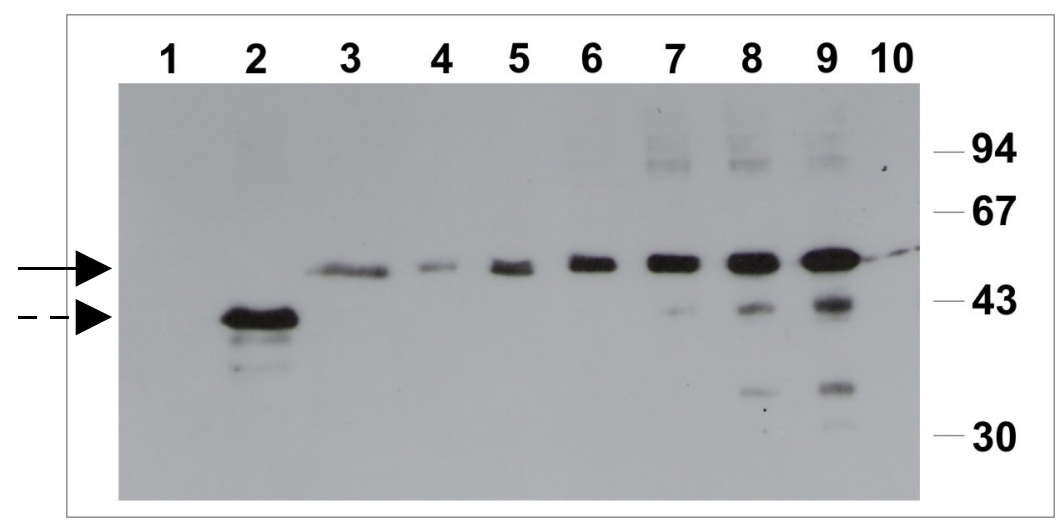

Fig 32 - Quantificação de PspA3' em L. helveticus: (canal 1) pT1NX; (canal 2) pT1NX-ab3; (canal 3) pT1NX-pspA3'; (canal 4) 10ng, (canal 5) 20ng, (canal 6) 40ng, (canal 7) 80ng, (canal 8) 160ng, (canal 9) 320ng de PspA3' purificada de E. coli; (canal 10) marcador de massa molecular de proteínas; A seta cheia indica as bandas específicas da proteína PspA3'; A seta tracejada indica a banda da proteína AB3.

Um problema, já visualizado anteriormente, é que as proteínas PspA1' e AB1, expressas nas bactérias lácticas, não formam uma banda única, o que dificulta sua quantificação, quando comparadas com a proteína recombinante purificada de E. coli (vide exemplo na figura 15).

Outro problema foi a dificuldade de se obter uma diluição confiável dos diferentes clones recombinantes de L. lactis, que pudesse ser quantificada por Western-blot.

Tabela 1 - Quantificação de PspA produzida nas bactérias recombinantes

\begin{tabular}{ccc}
\hline Bactérias $^{\text {Utilizadas }}{ }^{\text {a }}$ & $\begin{array}{c}\text { Quantidade estimada } \\
\text { de proteína produzida }\end{array}$ & $\begin{array}{c}\text { CFU utilizada em determinada } \\
\text { DO (em média) }\end{array}$ \\
\hline LC-pspA1 & $130 \mathrm{ng}$ & $\approx 10^{9} \mathrm{em}$ DO 1,5 \\
LC-ab1 & $130 \mathrm{ng}$ & $\approx 10^{9} \mathrm{em}$ DO 1,5 \\
LC-pspA3 & $80 \mathrm{a} 100 \mathrm{ng}$ & $\approx 10^{9} \mathrm{em}$ DO 1,5 \\
LC-ab3 & $100 \mathrm{ng}$ & $\approx 10^{9} \mathrm{em} \mathrm{DO} 1,5$ \\
& & $\approx 10^{7} \mathrm{em} \mathrm{DO} 1,3$ \\
LH-pspA1 & $100 \mathrm{a} 170 \mathrm{ng}$ & $\approx 10^{7} \mathrm{em}$ DO 1,4 \\
LH-ab1 & $260 \mathrm{ng}$ & $\approx 10^{9} \mathrm{em}$ DO 1,6 \\
LH-pspA3 & $10 \mathrm{ng}$ & $\approx 10^{7} \mathrm{em}$ DO 1,3 \\
LH-ab3 & $300 \mathrm{ng}$ &
\end{tabular}

a- Bactérias recombinantes expressando a proteína heteróloga intracelularmente, exceto em "ss", indicando a expressão ancorada à parede; b- Possível erro experimental a ser confirmado.

LC - L. casei; $\mathrm{LH}-$ L. helveticus 


\subsection{Análise preliminar da produção de anticorpos anti-PspA' em camundongos após $3^{\mathrm{a}}$ imunização}

Para uma análise inicial da capacidade de indução de resposta imune in vivo pelas bactérias lácticas recombinantes, utilizou-se camundongos C57Bl/6 fêmeas. Nestes experimentos preliminares, foram utilizados L. lactis (descrito como LL), L. casei (descrito como LC) e L. helveticus (descrito como LH), portando o vetor pT1NX como controle negativo, ou expressando PspA1' na porção intracelular. Estas bactérias foram crescidas em seus respectivos meios de cultura, até $\mathrm{DO}_{600} 1,6$ para L. lactis, $\mathrm{DO}_{550} 2,0$ para L. casei e $\mathrm{DO}_{660}$ 1,6 para L. helveticus, que correspondem às DOs da fase estacionária de cada bactéria recombinante. Depois de coletadas, e preparadas as alíquotas para imunização, foram realizadas diluições seriadas das diferentes culturas para contagem das CFUs que foram inoculadas nos animais. Após a terceira imunização dos camundongos, foram coletados sangue (individualmente) e saliva ("pool") de todos os animais, para análise pela técnica de ELISA da presença de IgG e IgA anti-PspA1' nas amostras, respectivamente. A seguir descreve-se: L. lactis-PspA1', L. casei-PspA1', L. helveticus-PspA1', que correspondem às respectivas bactérias expressando a proteína heteróloga no meio intracelular.

\section{Avaliação de IgG}

A figura 33 mostra a resposta de anticorpos do tipo IgG anti-PspA1' dos animais que foram imunizados com L. lactis-pT1NX e L. lactis-PspA1', após a administração de $10^{14}$ CFU/dose (dados obtidos após incubação das placas com as diluições seriadas das culturas). Houve uma pequena produção de anticorpos anti-PspA1' nos animais imunizados com $L$. lactis-PspA1', que foi significativamente diferente da salina $(P<0,05)$. Entretanto, esta resposta não foi significativamente diferente dos animais imunizados com L. lactis-pT1NX. Isto confere com os resultados obtidos em nosso grupo (Oliveira, et al., 2006 in press, vide Anexos), porém difere de resultados apresentados na literatura. Um exemplo é a indução de anticorpos do tipo IgG por lactococos recombinantes expressando TTFC (Grangette et al., 2002; Robinson et al., 1997; Norton et al., 1997), com títulos de até $10^{4}$. Isto pode ser explicado por diferenças de imunogenicidade dos antígenos, condições de crescimento e sistemas de expressão utilizados. Outra diferença foi a alta quantidade de bactéria inoculada $\left(10^{14}\right)$ em nosso experimento, que poderia induzir tolerância ao antígeno no animal. Esta alta dose de lactococos utilizada por animal refere-se a grande quantidade desta bactéria presente 
na DO utilizada, e a dificuldade na obtenção de uma diluição confiável contendo $10^{8}$ bactérias, conforme utilizado para lactobacilos.

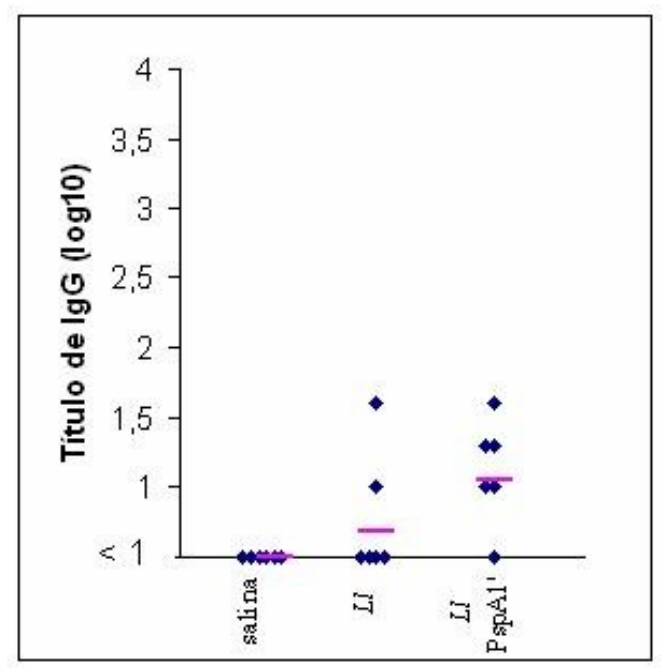

Fig 33 - Avaliação de anticorpos anti-PspA1' do tipo IgG induzidos por L. lactis recombinantes, analisados no soro dos animais C57BI/6: Cada ponto representa um animal; Barras representam as médias dos logaritmos dos títulos de anticorpos entre todos os animais de uma mesma condição.

A figura 34 mostra a resposta individual de anticorpos do tipo IgG anti-PspA1', presentes no soro dos animais imunizados com L. casei-pT1NX e L. casei-PspA1'. Foi possível observar que L. casei expressando PspA1' induziu a produção de IgG anti-PspA1' com um título médio de 1/1183, após a administração de $7 \times 10^{8} \mathrm{CFU} /$ dose. Sendo que estes títulos foram significativamente diferentes dos animais que receberam salina ou L. casei portando o vetor vazio $(P<0,01)$.

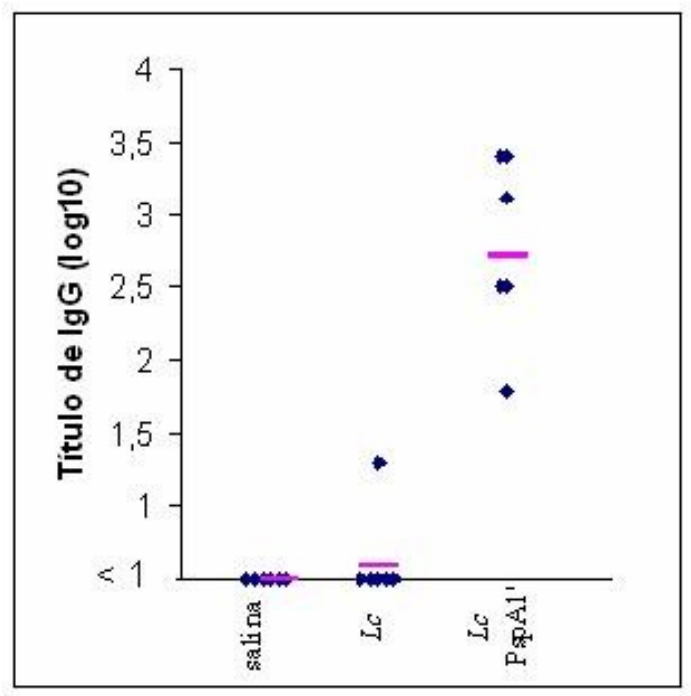

Fig 34 - Avaliação de anticorpos anti-PspA1' do tipo IgG induzidos por L. casei recombinantes, analisados no soro dos animais $\mathrm{C} 57 \mathrm{BI} / 6$ : Cada ponto representa um animal; Barras representam as médias dos logaritmos dos títulos de anticorpos entre todos os animais de uma mesma condição. 
Para L. helveticus-PspA1', também se observou a indução de anticorpos nos animais imunizados com esta bactéria, como mostra a figura 35. Ele induziu uma resposta menor (com título de 1/23 em média), que foi significativamente diferente dos títulos dos animais que receberam a salina ou $L$. helveticus-pT1NX $(P<0,01)$. Cada dose administrada a estes animais foi de $2 \times 10^{8}$ CFU de L. helveticus/animal.

Nestes experimentos preliminares de imunização, foi possível perceber que os grupos controles, bactérias lácticas transformadas com os vetores sem o gene de interesse, apresentaram níveis baixos de anticorpos como o grupo salina.

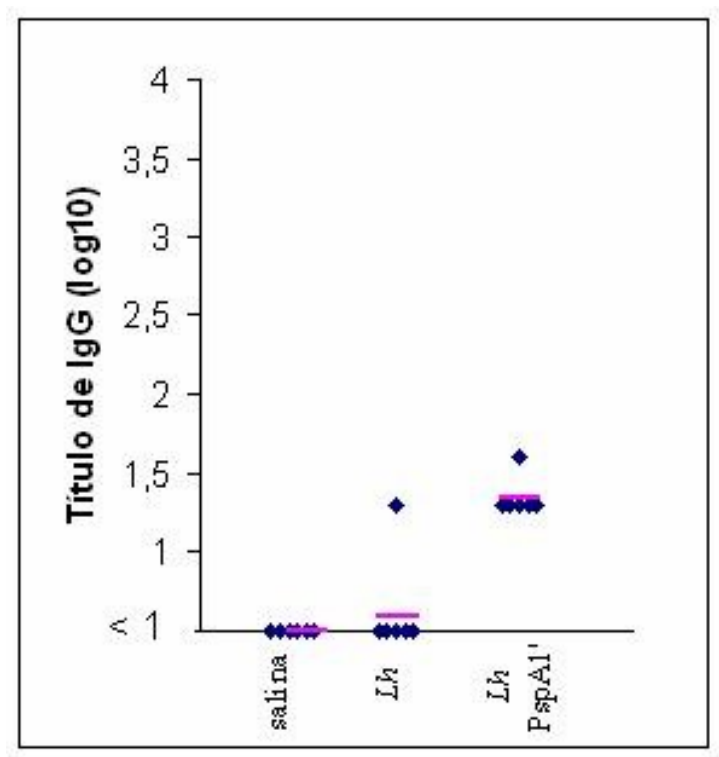

Fig 35 - Avaliação de anticorpos anti-PspA1' do tipo IgG induzidos por L. helveticus recombinantes, analisados no soro dos animais $\mathrm{C} 57 \mathrm{Bl} / 6$ : Cada ponto representa um animal; Barras representam as médias dos logaritmos dos títulos de anticorpos entre todos os animais de uma mesma condição.

Com base nestes resultados, realizou-se um novo experimento em $\mathrm{C} 57 \mathrm{Bl} / 6$, na tentativa de igualar a quantidade de bactéria utilizada nas diferentes condições. Entretanto, neste experimento não foi utilizado L. lactis, uma vez que os resultados da figura 33 não indicaram diferenças significativas entre LL-pspA1' e LL-pT1NX, e devido à dificuldade de se obter com segurança $10^{8}$ bactérias. Portanto, foram utilizadas as bactérias L. casei-pT1NX, L. casei-PspA1', L. helveticus-pT1NX e L. helveticus-PspA1' para imunização dos animais, além de um grupo que recebeu apenas salina. Com base nas curvas de crescimento, percebeuse que os L. helveticus permaneceram por muito tempo na DO correspondente à fase estacionária no experimento anterior, o que poderia acarretar a presença de bactérias mortas (tempo de cultivo 50h). Por este motivo, decidiu-se utilizar as bactérias na $\mathrm{DO}_{660}$ 1,3 (em 
média), que pela curva (figura 28), corresponde ao final da fase exponencial. De fato, apesar da DO utilizada ser menor, o número de bactérias inoculado por animal neste experimento foi igual $\left(1 \times 10^{8} \mathrm{CFU}\right)$, apesar do maior volume de cultura coletado. Isto indica a presença de bactérias mortas no inóculo do experimento anterior. Para este experimento, utilizou-se $L$. casei nas mesmas condições do experimento anterior, cujo inóculo por animal correspondeu à $2 \times 10^{8} \mathrm{CFU} /$ dose.

A figura 36 mostra que L. casei-PspA1' foi capaz de induzir a produção de anticorpos do tipo IgG nos camundongos, com título médio de 1/1108. Com base na mesma figura, observa-se que L. helveticus-PspA1' levou à indução de anticorpos IgG anti-PspA1' com título médio de 1/384. Novamente, ambas as bactérias (L. casei-PspA1' e L. helveticusPspA1') induziram títulos de anticorpos significativamente diferente da salina e das bactérias portando o vetor vazio $(P<0,01)$.

Os resultados obtidos para L. casei, nestes dois experimentos, diferem dos resultados obtidos anteriormente pelo nosso grupo, que mostraram uma melhor resposta imune para $L$. helveticus, e mais baixa para L. casei expressando o antígeno PsaA (L. casei-PsaA) de $S$. pneumoniae (Oliveira, et al., 2006 in press, vide Anexos). Isto talvez possa ser explicado pela menor quantidade de L. helveticus utilizada nestes experimentos, já que os resultados positivos foram conseguidos pelo nosso grupo com imunização de $10^{9}$ bactérias por animal. Não podem ser descartadas também, possíveis diferenças em relação aos antígenos de pneumococo, e o fato da proteína PsaA naquele trabalho estar localizada na parede celular. Alguns trabalhos mostraram que L. casei foi capaz de induzir a produção de anticorpos contra antígenos expressos de forma constitutiva, entretanto, quando comparada a outras linhagens de lactobacilos a eficiência desta linhagem em estimular o sistema imune foi menor (Seegers, 2003). 


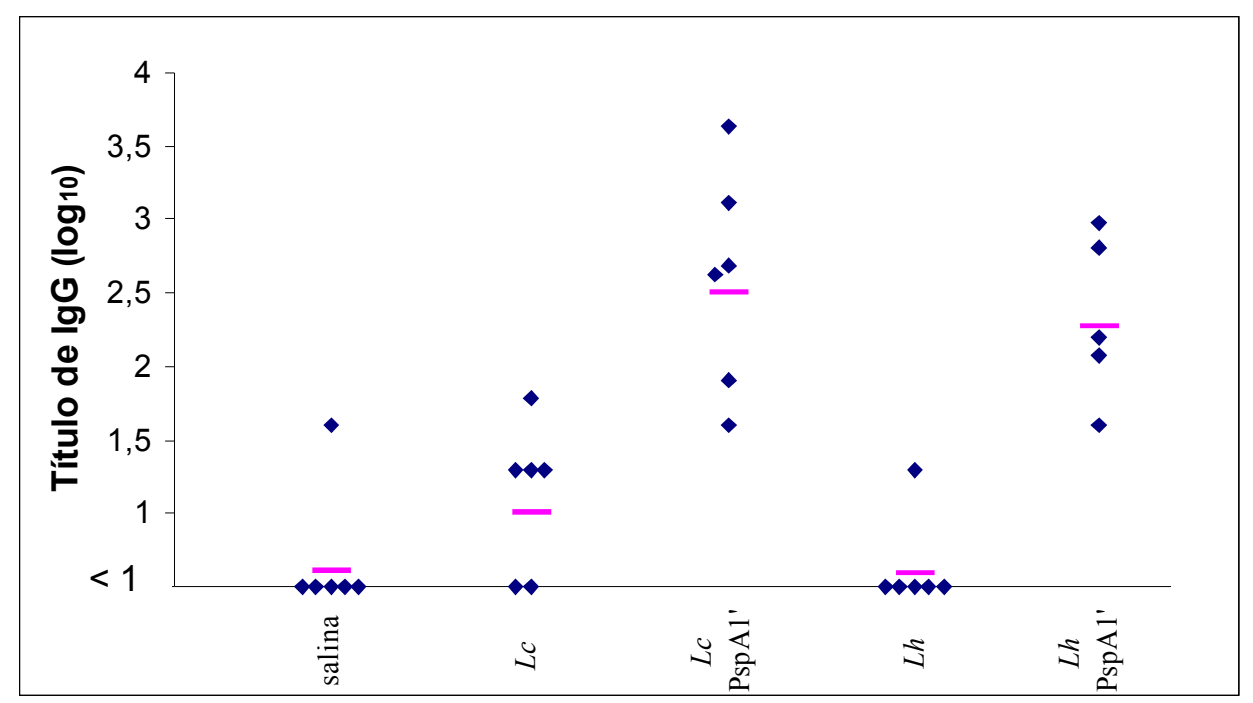

Fig 36 - Avaliação de anticorpos anti-PspA1' do tipo IgG induzidos pelas bactérias lácticas recombinantes, analisados no soro dos animais C57BI/6: Cada ponto representa um animal; Barras representam as médias dos logaritmos dos títulos de anticorpos entre todos os animais de uma mesma condição.

\section{$\underline{\text { Avaliação de } \operatorname{IgA}}$}

Para análise da resposta de anticorpos do tipo $\operatorname{IgA}$, induzida pelas bactérias lácticas utilizadas, avaliou-se por ELISA a saliva de todos os animais utilizados nos experimentos descritos anteriormente. A partir de uma diluição da saliva de 1/4 para todas as condições, foi possível observar que L. casei-PspA1' teve uma tendência maior de produção de anticorpos, quando comparado com os demais, porém não significativo. Estes resultados diferem dos obtidos em nosso grupo, que mostraram títulos significativos de IgA anti-PsaA na saliva induzidos por L. helveticus-PsaA e L. plantarum-PsaA, após administração intranasal, por volta de 1/30 (Oliveira, et al., 2006 in press, vide Anexos). Difere também de outros trabalhos, como por exemplo a indução de $\operatorname{IgA}$, com títulos de $10^{2,5}$, após imunização intranasal de L. plantarum-TTFC (Grangette et al., 2001; Reveneau et al., 2002). Isto evidencia que lactobacilos são capazes de induzir a produção de anticorpos do tipo $\operatorname{IgA}$, entretanto isto pode variar entre as espécies e o antígeno utilizado. Outra possível explicação para os títulos de anticorpos do tipo IgA não terem sido detectados na saliva seria a ausência de indução de sítios de mucosa distintos, já que a imunização foi nasal e a análise de IgA foi da saliva. Não foram avaliados os lavados nasais e brônquicos destes animais, pois eles foram utilizados no ensaio de desafio. 


\section{$\underline{\text { Avaliação em BALB/c }}$}

Devido à dificuldade de obtermos animais $\mathrm{C} 57 \mathrm{Bl} / 6$, realizamos alguns experimentos em camundongos $\mathrm{BALB} / \mathrm{c}$ (dados não mostrados). Entretanto, como observado em experimentos anteriores no nosso laboratório, utilizando as bactérias lácticas expressando diferentes antígenos, houve uma resposta inespecífica muito alta, principalmente nos animais inoculados com as bactérias contendo os vetores vazios. Além disso, a variação de títulos de anticorpos observados nos animais dentro do mesmo grupo é muito grande, gerando então resultados inconclusivos. Isto evidencia que os animais $\mathrm{BALB} / \mathrm{c}$ não são ideais para a avaliação de indução de anticorpos por bactérias lácticas nas condições utilizadas neste trabalho. Além disso, a maioria dos trabalhos com bactérias lácticas, presentes na literatura, foram realizados em camundongos $\mathrm{C} 57 \mathrm{Bl} / 6$, sugerindo a importância desta linhagem para este tipo de avaliação.

\section{$\underline{\text { Desafio }}$}

Após 14 dias da última imunização, os animais C57B1/6 foram desafiados via intraperitoneal com $2 \times 10^{6}$ bactérias da cepa 491/00 de Streptococcus pneumoniae, que possui a proteína PspA do clado 1. No período de duas semanas todos os animais morreram, exceto um que foi imunizado com L. casei-PspA1', sendo que este foi o animal que apresentou o maior título de anticorpos (IgG). Entretanto, um animal sobrevivente em 6 testados com a mesma condição não representa um índice significativo.

De acordo com resultados obtidos pelo grupo que trabalha com vacinas contra $S$. pneumoniae no Instituto Butantan, e comunicação pessoal com o Dr. David E. Briles (Departmento de Microbiologia da Universidade do Alabama, EUA), os desafios realizados por via intraperitoneal geram uma inflamação muito grande, e são mais difíceis de serem controlados. Novos desafios, com diferentes cepas de pneumococo, estão sendo estabelecidos atualmente pela via intravenosa, com resultados promissores. Portanto, estes desafios devem agora ser aplicados em novos experimentos de imunização com as bactérias lácticas recombinantes expressando PspA. 


\section{Conclusões}

Os resultados apresentados nesta dissertação indicam que foi possível a expressão constitutiva das proteínas de interesse PspA1', PspA3', AB1 e AB3 em todas as bactérias utilizadas: L. lactis, L. casei e L. helveticus. E esta expressão pode ser direcionada para localização intracelular ou ancorada à parede celular. As construções de ancoramento à parede celular só foram realizadas para os fragmentos maiores de PspA, e não foram obtidas em $L$. helveticus.

Os Western-blots evidenciaram a presença das proteínas de interesse nos lisados celulares de todas as bactérias, além de alta especificidade aos anticorpos. Inesperadamente, apenas para PspA1' e AB1, foi visto um padrão de várias bandas na altura do tamanho esperado, em todos os lisados celulares de todas as bactérias. Entretanto, isto não alterou a imunogenicidade desta proteína, já que foram obtidos anticorpos contra ela em experimentos de imunização nasal de camundongos. No meio de cultura, também foi observada uma pequena quantidade da proteína de interesse. Já que as construções intracelulares não possuíam o peptídeo sinal, que foi retirado do vetor antes da clonagem dos genes, esta presença refere-se, provavelmente, a um pouco de lise celular, em índices baixos mas suficientes para detecção.

Para as bactérias transformadas com as construções de ancoramento, foi possível comprovar a presença das proteínas heterólogas ancoradas à parede celular. Isto foi possível através do ensaio em que anticorpos específicos foram incubados com as bactérias íntegras. Além disso, foi possível comprovar a ausência da exposição das proteínas de interesse nas bactérias transformadas com as construções intracelulares.

Através das curvas de crescimento, foi possível visualizar que as diferentes bactérias lácticas precisam de diferentes tempos de incubação para alcançar determinada fase do crescimento. Além disso, após plaqueamento das diluições seriadas das culturas, foi possível constatar uma grande diferença na quantidade de CFU entre as diferentes bactérias lácticas utilizadas, em uma mesma DO.

Também por Western-blot, foi possível estimar a quantidade das proteínas heterólogas produzidas pelos lactobacilos, com base em curvas de PspA1' e PspA3' purificadas de E. coli. Sendo que esta quantidade variou de acordo com a bactéria utilizada e o tamanho do fragmento expresso. Contudo, a quantificação foi dificultada para PspA1' e AB1, devido a formação de várias bandas próximas da altura esperada. Além disso, também houve 
problemas na quantificação das proteínas produzidas por L. lactis recombinantes, devido a dificuldade de se obter uma diluição confiável dos diferentes clones, que pudesse ser quantificada por Western-blot.

Os resultados de ELISA, após a imunização nasal de camundongos com L. lactis, $L$. casei e L. helveticus, todos expressando PspA1' no meio intracelular, estão resumidos na tabela 2. Alguns experimentos de imunização em camundongos BALB/c mostraram uma grande variação, inclusive entre animais de um mesmo grupo, e não geraram resultados conclusivos. Além disso, foi demonstrado que esta linhagem apresenta resposta inespecífica às bactérias portando os vetores vazios. Isto evidencia que a obtenção de anticorpos neste sistema é dependente da linhagem de camundongo, já que todos os experimentos foram realizados nas mesmas condições.

\section{Tabela 2 - Resumo dos títulos de anticorpos obtidos em animais nas diferentes condições experimentais}

\begin{tabular}{|c|c|}
\hline $\begin{array}{c}\text { Bactérias utilizadas } \\
\text { nos experimentos de } \\
\text { imunização }\end{array}$ & Títulos \\
\hline $\begin{array}{l}\text { LL-pT1NX } \\
\text { LL-PspA1' }\end{array}$ & $\begin{array}{l}- \\
+\end{array}$ \\
\hline $\begin{array}{l}\text { LC-pT1NX } \\
\text { LC-PspA1' } \\
\text { LH-pT1NX } \\
\text { LH-PspA1' }\end{array}$ & $\begin{array}{c}-,+^{\mathrm{a}} \\
+++++ \\
- \\
+,++++^{\mathrm{a}}\end{array}$ \\
\hline
\end{tabular}

A tabela 5 mostra que tanto $L$. casei-PspA1' quanto L. helveticus-PspA1' foram capazes de induzir anticorpos do tipo IgG anti-PspA1' no soro dos animais C57B1/6. Os resultados obtidos pela imunização com L. casei-PspA1' foram bem reproduzidos nos dois experimentos. Títulos um pouco mais altos de IgG anti-PspA1' parecem ter sido obtidos após a imunização com L. helveticus-PspA1' no segundo experimento. Isto pode refletir o fato de termos utilizado culturas em fase anterior à estacionária. Entretanto, estes dados ainda devem ser confirmados.

Para L. lactis, houve uma baixa indução de anticorpos em C57B1/6, o que difere dos resultados obtidos na literatura para outros antígenos. Isto pode ser explicado por diferentes razões: 
(a) pela alta quantidade de bactéria inoculada, que pode ter causado tolerância ao antígeno nos animais. Porém, esta é uma hipótese que ainda deve ser avaliada. Uma possível solução para este problema seria a utilização desta bactéria em $\mathrm{DO}=0,5$, pois seria possível aliquotar $10^{9}$ bactérias com maior segurança, conforme gráfico da figura 29. Porém, há a necessidade prévia de quantificar o antígeno, no caso de se utilizar menor quantidade de L. lactis, para controle maior dos novos experimentos de imunização a serem realizados;

(b) pela fase de crescimento estacionária que foi utilizada, talvez a fase log possa induzir maiores títulos. Esta hipótese corrobora com os dados presentes na literatura, que evidenciaram a indução de anticorpos por L. lactis, quando este foi utilizado em fase exponencial (Grangette et al., 2002). Além disso, já foi visto que a resposta imune pode variar para uma mesma bactéria láctica, de acordo com sua fase de crescimento (Maassen et al., 2003);

(c) pela diferença entre os antígenos utilizados em trabalhos da literatura e neste trabalho, ou seja, eles possuem potenciais imunogênicos diferentes.

No experimento de desafio, houve apenas um sobrevivente, coincidentemente, aquele que apresentou o maior título de anticorpos IgG. Contudo, novos experimentos de desafio, com a utilização de diferentes cepas de pneumococo, e outras vias de inoculação estão programados para a conclusão do trabalho.

Este trabalho descreve pela primeira vez a expressão constitutiva da proteína PspA de S. pneumoniae em bactérias lácticas. Estas linhagens mostraram-se boas apresentadoras do antígeno PspA1', e também se mostraram capazes de induzir uma resposta imune humoral específica contra esta proteína em camundongos imunizados pela via de mucosa. Estudos mostraram que anticorpos anti-PspA são protetores em ensaios de desafio em camundongos (Areas et al., 2005; Briles et al., 2001). Isto sugere que em experimentos de desafio bem estabelecidos, os anticorpos induzidos pelas bactérias lácticas poderiam conferir proteção aos animais imunizados. Os resultados obtidos anteriormente pelo nosso grupo, que mostraram a inviabilidade de linhagens de lactobacilos expressando PspA na forma induzível em estimular uma resposta imune após imunização de mucosa (dados não publicados), evidenciam que os dados apresentados nesta dissertação são promissores, mostrando a viabilidade do desenvolvimento de vacinas bacterianas vivas baseadas em lactobacilos expressando candidatos vacinais constitutivamente. 


\section{Referências bibliográficas ${ }^{1}$}

Aires KA, Cianciarullo AM, Carneiro SM, Villa LL, Boccardo E, Perez-Martinez G, PerezArellano I, Oliveira ML, Ho PL. Production of human papillomavirus type 16 L1 virus-like particles by recombinant Lactobacillus casei cells. Appl Environ Microbiol. 2006, 72 (1): 745-752.

American Academy of Pediatrics. Committee on Infectious Diseases. Policy statement: recommendations for the prevention of pneumococcal infections, including the use of pneumococcal conjugate vaccine (Prevnar), pneumococcal polysaccharide vaccine, and antibiotic prophylaxis. Pediatrics. 2000, 106 (2Pt 1): 362-366.

Areas AP, Oliveira ML, Miyaji EN, Leite LC, Ho PL. Intradermal immunization of mice with cholera toxin B-pneumococcal surface protein A fusion protein is protective against intraperitoneal challenge with Streptococcus pneumoniae. Infect Immun. 2005, 73 (6): 38103813.

Avery OT, McLeod CM, McCarty M. Sudies on the chemical nature of the substance inducing transformation of pneumococcal types. Induction of transformation by a deoxyribonucleic acid fraction isolated from pneumococcus type III. $J$ Exp Med. 1944, 79: $137-158$

Balachandran P, Brooks-Walter A, Virolainen-Julkunen A, Hollingshead SK, Briles DE. Role of pneumococcal surface protein $\mathrm{C}$ in nasopharyngeal carriage and pneumonia and its ability to elicit protection against carriage of Streptococcus pneumoniae. Infect Immun. 2002, 70 (5): 2526-2534.

Bogaert D, Hermans PWM, Adrian PV, Riimke HC, de Groot R. Pneumococcal vaccines: an update on current strategies. Vaccine. 2004a, 22 (17-18): 2209-2220

Bogaert D, de Groot R, Hermans PW. Streptococcus pneumoniae colonisation: the key to pneumococcal disease. Lancet Infect Dis. 2004b, 4 (3): 144-154

Brandileone MCC, de Andrade ALSS, Di Fabio JL, Guerra MLLS, Austrian R. Appropriateness of pneumococcal conjugate vaccine in Brazil: Potential impact of age and clinical diagnosis, with emphasis on meningitis. J Infect Dis. 2003, 187: 1206-1212

Brandileone MCC, Andrade ALSS, Teles EM, Zanella RC, Yara TI, Di Fabio JL, Hollingshead SK. Typing of pneumococcal surface protein A (PspA) in Streptococcus pneumoniae isolated during epidemiological surveillance in Brazil: towards novel pneumococcal protein vaccines. Vaccine. 2004, 22: 3890-3896.

Briles DE, Hollingshead S, Brooks-Walter A, Nabors GS, Ferguson L, Schilling M, Gravenstein S, Braun P, King J \& Swift A. The potential to use PspA and other

\footnotetext{
${ }^{1}$ International Committee of Medical Journal Editors. Uniform requirements for manuscripts submitted to Biomedical Journal: sample references. Available from: http://www.icmj.org [2004 May 06]. National library of medicine. List of journals indexed in Index Medicus, 2001. Available from: http://www.ncbi.nlm.nih.gov/entrez/browser.cgi, www.nlm.nih.gov/tsd/serials/lji.html .
} 
pneumococcal proteins to elicit protection against pneumococcal infection. Vaccine. 2000a, 18: $1707-1711$.

Briles DE, Ades E, Paton JC, Sampson JS, Carlone GM, Huebner RC, Virolainen A, Swiatlo E \& Hollingshead S. Intranasal immunization of mice with a mixture of the pneumococcal proteins PsaA and PspA is highly protective against nasopharyngeal carriage of Streptococcus pneumoniae. Infect Immun. 2000b, 68: 796-800.

Briles DE, Hollingshead S, King J, Swift A, Braun PA, Park MK, Ferguson LM, Nahm MH, Nabors GS. Immunization of humans with recombinant pneumococcal surface protein A (rPspA) elicits antibodies that passively protect mice from fatal infection with Streptococcus pneumoniae bearing heterologous PspA. J Infect Dis. 2000c, 182 (6): 1694-1701.

Briles DE, Hollingshead S, Nabors GS, Paton JC, Brooks-Walter A. The potential for using protein vaccines to protect against otitis media caused by Streptococcus pneumoniae. Vaccine. 2001, 19: S87-S95.

Butler JC, Schuchar A. Epidemiology of pneumococcal infections in the elderly. Drugs Aging. 1999, 15, (Suppl 1): 11-19.

Centers for Disease Control and Prevention (CDC). Prevention of Pneumococcal Disease: Recommendations of the Advisory Committee on Immunization Practices (ACIP). 1997, 46 (RR-08): 1-24.

Centers for Disease Control and Prevention (CDC). Direct and indirect effects of routine vaccination of children with 7-valent pneumococcal conjugate vaccine on incidence of invasive pneumococcal disease--United States, 1998-2003. MMWR Morb Mortal Wkly Rep. 2005, 54 (36): 893-897.

Chandan RC. Enhancing market value of milk by addicing cultures. J Dairy Sci. 1999, 82 (10): 2245-2256.

Corthesy B, Boris S, Isler P, Grangette C, Mercenier A. Oral immunization of mice with lactic acid bacteria producing Helicobacter pylori Urease B subunit partially protects against challenge with Helicobacter felis. J Infect Dis. 2005, 192: 1441-1449.

Diekema DJ, Brueggemann AB, Doern GV. Antimicrobial-drug use and changes in resistance in Streptococcus pneumoniae. Emerg Infect Dis. 2000, 6 (5): 552-556.

Fedson DS, Scott JA. The burden of pneumococcal disease among adults in developed and developing countries: what is and is not known. Vaccine. 1999b, 17 (Suppl 1): S11-18.

Fedson DS. The clinical effectiveness of pneumococcal vaccination: a brief review. Vaccine. 1999b, 17 (Suppl 1): S85-90.

French N, Nakiyingi J, Carpenter LM, Lugada E, Watera C, Moi K, Moore M, Antvelink D, Mulder D, Janoff EM, Whitworth J, Gilks CF. 23-valent pneumococcal polysaccharide vaccine in HIV-1-infected Ugandan adults: double-blind, randomised and placebo controlled trial. Lancet. 2000, 355 (9221): 2106-2111. 
Gluck U, Gebbers JO. Ingested probiotcs reduce nasal colonization with pathogenic bacteria (Staphylococcus aureus, Streptococcus pneumoniae, and $\beta$-hemolitic streptocci). Am J Clin Nutr. 2003, 77 (2): 517-520.

Grangette C, Müller- Alouf H, Goudercourt D, Geoffroy M-C, Turneer M \& Mercenier A. Mucosal immune responses and protection against tetanus toxin after intranasal immunization with recombinant Lactobacillus plantarum. Infect Immun. 2001, 69: 1547-1553.

Grangette C, Müller- Alouf H, Geoffroy M-C, Goudercourt D, Turneer M \& Mercenier A. Protection against tetanus toxin after intragastric administration of two recombinant lactic acid bacteria: impact of strain viability and in vivo persistence. Vaccine. 2002, 20: 3304-3309

Gutierrez RC, Santos V, Nader-Macías ME. Protective effect of intranasally inoculated Lactobacillus fermentum against Streptococcus pneumoniae challenge on the mouse respiratory tract. FEMS Immun Med Microbiol. 2001, 31: 187-195.

Hammerschmidt S, Bethe G, Remane PH, Chhatwal GS. Identification of Pneumococcal Surface Protein A as a Lactoferrin-Binding Protein of Streptococcus pneumoniae. Infect Immun. 1999, 67 (4): 1683-1687.

Hausdorff WP, Feikin DR, Klugman KP. Epidemiological differences among pneumococcal serotypes. Lancet Infect Dis. 2005, 5 (2): 83-93.

Henrichsen J. Six newly recognized types of Streptococcus pneumoniae. J Clin Microbiol. 1995, 33 (10): 2759-2762.

Ho PS, Kwang J, Lee YK. Intragastric administration of Lactobacillus casei expressing transmissible gastroentritis coronavirus spike glycoprotein induced specific antibody production. Vaccine. 2005, 23: 1335-1342.

Hoffman-Roberts HL, Babcock EC, Mitropoulos IF. Investigational new drugs for the treatment of resistant pneumococcal infections. Expert Opin Investig Drugs. 2005, 14 (8): 973-995

Holck A \& Naes H. Cloning, sequencing and expression of the gene encoding the cellenvelope-associated proteinase from Lactobacillus paracasei subsp. paracasei NCDO 151. J Gen Microbiol. 1992, 138: 1353-1364.

Hollingshead S, Becker R, Briles DE. Diversity of PspA: Mosaic genes and evidence for past recombination in Streptococcus Pneumoniae. Infect Immun. 2000, 68: 5889-5900.

Holzapfel WH, Haberer P, Snel J, Schillinger U, Huis in't Veld JH. Overview of gut flora and probiotics. Int J Food Microbio. 1998, 41: 85-101.

Ibnou-Zekri N, Blum S, Schiffrin EJ, vonderWeid T. Divergent patterns of colonization and immune response elicited from two intestinal Lactobacillus strains that display similar properties in vitro. Infect Immun. 2003, 71: 428-436.

Jedrzejas MJ. Pneumococcal virulence factors: structure and function. Microbiol Mol Biol Rev. 2001, 65: 187-207. 
Kim PE, Musher DM, Glezen WP, Rodriguez-Barradas MC, Nahm WK, Wright CE. Association of invasive pneumococcal disease with season, atmospheric conditions, air pollution, and the isolation of respiratory viruses. Clin Infect Dis. 1996, 22 (11): 100-106.

Koskela M, Leinonen M, Haiva VM, Timonen M, Makela PH. First and second dose antibody responses to pneumococcal polysaccharide vaccine in infants. Pediatr Infect Dis. 1986, 5 (1): 45-50.

Laible G, Spratt BG, Hakenbeck R. Interspecies recombinational events during the evolution of altered PBP 2x genes in penicillin-resistant clinical isolates of Streptococcus pneumoniae. Mol Microbiol. 1991, 5 (8): 1993-2002.

Lipsitch M, Dykes JK, Johnson SE, Ades EW, KINg J, Briles DE, Carlone GM. Competition among Streptococcus pneumoniae for intranasal colonization in a mouse model. Vaccine. 2000, 18 (25): 2895-2901

Lopez R, Garcia E. Recent trends on the molecular biology of pneumococcal capsules, lytic enzymes, and bacteriophage. FEMS Microbiol Rev. 2004, 28 (5): 553-580.

Maassen CBM, vanHolten-Neelen C, Balk F, denBak-Glashouwer M-J H, Leer RJ, Laman JD, Boersma WJA, Claasen E. Strain-dependent induction of cytokine profiles in the gut by orally administered Lactobacillus strains. Vaccine. 2000, 18: 2613-2623.

Maassen CBM, Boersma WJA, vanHolten-Neelen C, Claasen E \& Laman JD. Growth phase of orally administered Lactobacillus strains differentially affects IgG1/IgG2a ratio for soluble antigens: implications for vaccine development. Vaccine. 2003, 21: 2751-2757.

Magee AD, Yother J. Requirement for capsule in colonization by Streptococcus pneumoniae. Infect Immun. 2001, 69 (6): 3755-3761.

Mantese OC, Paula A, Moraes AB, Moreira TA, Guerra ML, Brandileone MC. Prevalence of serotypes and antimicrobial resistance of invasive strains of Streptococcus pneumoniae. $J$ Pediatr (Rio J). 2003, 79 (6): 537-542.

Matsumoto S, Hara T, Hori T, Mitsuyama K, Nagaoka M, Tomiyasu N, Suzuki A, Sata M. Probiotic Lactobacillus-induced improvement in murine chronic inflammatory bowel disease is associated with the down-regulation of pro-inflammatory cytokines in lamina propria mononuclear cells. Clin Exp Immunol. 2005, 140 (3): 417-426.

McCormick AW, Whitney CG, Farley MM, Lynfield R, Harrison LH, Bennett NM, SchaffnenW, Reingold A, Hadler J, Cieslak P, Samore MH, Lipsitch M. Geographic diversity and temporal trends of antimicrobial resistance in Streptococcus pneumoniae in the United States. Nat Med. 2003, 9 (4): 424-430.

Meurman JH. Probiotics: do they have a role in oral medicine and dentistry? Eur J Oral Sci. 2005, 113: 188-196.

Miyaji EN, Ferreira DM, Lopes AP, Brandileone MC, Dias WO, Leite LCC. Analysis of serum cross-reactivity and cross-protection elicited by immunization with DNA vaccines 
against Streptococcus pneumoniae expressing PspA fragments from different clades. Infect Immun. 2002a, 70 (9): 5086-5090.

Miyaji EN, Dias WO, Gamberini M, Gebara VCBC, Schenkman RPF, Wild J, Riedl P, Reimann J, Schirmbeck R, Leite LCC. PsaA and PspA DNA vaccines induce humoral and cellular immune responses against Streptococcus pneumoniae. Vaccine. 2002b, 20: 805-812.

Nabors GS, Braun PA, Herrmann DJ, Heise ML, Pyle DJ, Gravenstein S, Schilling M, Ferguson LM, Hollingshead S, Briles DE, Becker RS. Immunization of healthy adults with a single recombinant pneumococcal surface protein A (PspA) variant stimulates broadly crossreactive antibodies to heterologous PspA molecules. Vaccine. 2000, 18 (17): 1743-1754.

Nachman S, Kim S, King J, Abrams EJ, Margolis D, Petru A, Shearer WW, Smith E, Moye J, Blanchard S, Hawkins E, Bouquin P, Vink P, Benson M, Estep S, Malinoski F. Safety and immunogenicity of a heptavalent pneumococcal conjugate vaccine in infants with human immunodeficiency virus type 1 infection. Pediatrics. 2003, 112 (1 Pt 1): 66-73.

Nielsen H, Kvinesdal B, Benfield TL, Lundgren JD, Konradsen HB. Rapid loss of specific antibodies after pneumococcal vaccination in patients with human immunodeficiency virus-1 infection. Scand J Infect Dis. 1998, 30 (6): 597-601.

Norton PM, Wells JM, Brown HWG, Macpherson AM, Le Page RWF. Protection against tetanus toxin in mice nasally immunized with recombinant Lactococcus lactis expressing tetanus toxin fragment C. Vaccine. 1997, 15: 616-619.

Oliveira ML, Monedero V, Miyaji EN, Leite LC, Lee Ho P, Perez-Martinez G. Expression of Streptococcus pneumoniae antigens, PsaA (pneumococcal surface antigen A) and PspA (pneumococcal surface protein A) by Lactobacillus casei. FEMS Microbiol. 2003, 227 (1): 25-31.

Oliveira ML, Arêas APM, Campos IB, Monedero V, Perez-Martinez G, Miyaji EN, Leite LCC, Aires KA, Ho PL. Induction of systemic and mucosal immune response and decrease of Streptococcus pneumoniae colonization by nasal inoculation of mice recombinant lactic acid bacteria expressing the Pneumococcal Surface Antigen A (PsaA). J Microbes Infect. 2006, in press.

Ogunniyi AD, Folland RL, Briles DE, Hollingshead SK, Paton JC. Immunization of Mice with Combinations of Pneumococcal Virulence Proteins Elicits Enhanced Protection against Challenge with Streptococcus pneumoniae. Infect Immun. 2000, 68 (5): 3028-3033.

Ogunniyi AD, Woodrow MC, Poolman JT, Paton JC. Protection against Streptococcus pneumoniae Elicited by Immunization with Pneumolysin and CbpA. Infect Immun. 2001, 69 (10): 5997-6003.

Pai VB, Heyneman CA, Erramouspe J. Conjugated heptavalent pneumococcal vaccine. Ann Pharmacother. 2002, 36 (9): 1403-1413.

Peran L, Camuesco D, Comalada M, Nieto A, Concha A, Adrio JL, Olivares M, Xaus J, Zarzuelo A, Galvez J. Lactobacillus fermentum, a probiotic capable to release glutathione, 
prevents colonic inflammation in the TNBS model of rat colitis. Int $J$ Colorectal Dis. 2005, 11 (33): 5185-5192.

Perdigon G, Vintini E, Alvarez S, Medina M, Medici M. Study of the possible mechanisms involved in the mucosal immune system activation by lactic acid bacteria. J Dairy Sci. 1999, 2: $1108-1114$.

Pereira DI, Gibson GR. Cholesterol assimilation by lactic acid bactéria and bifidobacteria isolated from the human gut. Appl Environ Microbiol. 2002, 68 (9): 4689-4693.

Pichardo C, Docobo-Perz F, Pachon-Ibanez ME, Jimenez-Mejias ME, Garcia-Curiel A, Caballero-Granado FJ, Moreno-Maqueda I, Pachon J. Efficacy of \{beta $\}$-lactams against experimental pneumococcal endocarditis caused by strains with different susceptibilities to penicillin. J Antimicrob Chemother. 2005, 56(4): 732-737.

Pouwels PH, Leer RJ, Shaw M, Heijne den Bakb-Glashouwer MJ, Tielen FD, Smit E, Martinez B, Jore J, Conway PL. Lactic acid bacteria as antigen delivery vehicles for oral immunization purposes. Int J Food Microbiol. 1998, 41: 155-167.

Reid G. The scientific basis for probiotic strains of Lactobacillus. Appl Environ Microbiol. 1999, 65 (9): 3763-3766.

Ren B, Szalai AJ, Hollingshead SK, Briles DE. Effects of PspA and antibodies to PspA on activation and deposition of complement on the pneumococcal surface. Infect Immun. 2004, 72 (1): 114-122.

Reveneau N, Geoffroy MC, Locht C, Chagnaud P, Mercenier A. Comparison of the immune responses induced by local immunizations with recombinant Lactobacillus plantarum producing tetanus toxin fragment $\mathrm{C}$ in different cellular locations. Vaccine. 2002, 15; 20 (1314): 1769-1777.

Robinson K, Chamberlain LM, Schofield KM, Wells JM, Le Page RWF. Oral vaccination of mice against tetanus with recombinant Lactococcus lactis. Nat Biotech. 1997, 15: 653-657.

Rosenfeldt V, Michaelsen KF, Jakobsen M, Larsen CN, Moller PL, Pedersen P, Tvede M, Weyrehter H, Valerius NH, Paerregaard A. Effect of probiotc Lactobacillus strains in young clhidren hospitalized with acute diarrhea. Pediatr Infect Diseade J. 2002, 21 (5): 411-416.

Rubins JB, Alter M, Loch J, Janoff EN. Determination of antibody responses of elderly adults to all 23 capsular polysaccharides after pneumococcal vaccination. Infect Immun. 1999, 67 (11): 5979-5984.

Sankilampi U, Honkanen PO, Bloigu A, Leinonen M. Persistence of antibodies to pneumococcal capsular polysaccharide vaccine in the elderly. J Infect Dis. 1997, 176 (4): 1100-1104.

Scheppler L, Vogel M, Marti P, Muller L, Miescher SM, Stadler BM. Intranasal immunisation using recombinant Lactobacillus johnsonii as a new strategy to prevent allergic disease. Vaccine. 2005, 23 (9): 1126-1134. 
Scott JA, Hall AJ, Dagan R, Dixon JM, Eykyn SJ, Fenoll A, Hortal M, Jette LP, Jorgensen JH, Lamothe F, Latorre C, Macfarlane JT, Shlaes DM, Smart LE, Taunay A. Serogroupspecific epidemiology of Streptococcus pneumoniae: associations with age, sex, and geography in 7,000 episodes of invasive disease. Clin Infect Dis. 1996, 22 (6): 973-981.

Seegers JFML. Lactobacilli as live vaccine delivery vectors: progress and prospects. Trends in Biotechnol. 2002, 20 (12): 508-515.

Seegers JFML, Kremer SHA, Tielen FJ, Plomp AC, Verbeek R, Powels PH, vanNoort JM. Lactobacilli as live vaccine delivery vehicles. In: Moderns Vaccines Adjuvants and Delivery Systems Symposium. Dublin, Ireland, 2003.

Sessegolo JF, Levin AS, Levy CE, Asensi M, Facklam RR, Teixeira LM. Distribution of serotypes and antimicrobial resistance of Streptococcus pneumoniae strains isolated in Brazil from 1988 to 1992. J Clin Microbiol. 1994, 32(4): 906-911.

Shaw DM, Gaerthe B, Leer RJ, Van Der Stap JG, Smittenaar C, Heijne Den Bak-Glashouwer M, Thole JE, Tielen FJ, Pouwels PH, Havenith CE.Engineering the microflora to vaccinate the mucosa: serum immunoglobulin $\mathrm{G}$ responses and activated draining cervical lymph nodes following mucosal application of tetanus toxin fragment $\mathrm{C}$-expressing lactobacilli. Immunology. 2000, 100 (4): 510 -518.

Somkuti GA. Lactic acid bacteria. In: Lederberg J, editor. Encyclopedia of Microbiology. 2th ed. New York; 2000. vol 3, p. 1-8.

Steidler L, Hans W, Schotte L, Neirynck S, Obermeier F, Falk W, Fiers W, Remaut E. Treatment of murine colitis by Lactococcus lactis secreting interleukin-10. Science. 2000, 289: 1352-1355.

Teixeira LM, Trabulsi LR. Streptococcus, Enterococcus e gêneros relacionados; E Streptococcus pneumoniae. In: Trabulsi LR, Alterthum F, editores. Microbiologia. 4 ed. São Paulo: Atheneu, 2004: 189-193; 199-203.

Tu AHT, Fulgham RL, McCrory MA, Briles DE, Szalai AJ. Pneumococcal Surface Protein A Inhibits Complement Activation by Streptococcus pneumoniae. Infect Immun. 1999, 67 (9): $4720-4724$.

deVrese M, Stegelmann A, Ritcher B, Fenselau S, Laue C, Schrezenmeir J. Probiotcs compesnation for lactase insufficiency. Am J Clin Nutr. 2001, 73 (Suppl): 421S-429S.

Wagner RD, Pierson C, Warner T, Dohnalek M, Farmer J, Roberts L, Hilty M, Balish E. Biotherapeutic effects of probiotc bacteria on candidiasis in immunodficient mice. Infect Immun. 1997, 65 (10): 4165-4172.

Waterfield NR, Le Page RW, Wilson PW, Wells JM. The isolation of lactococcal promoters and their use in investigating bacterial luciferase synthesis in Lactococcus lactis. Gene. 1995, 165 (1): 9-15.

Weiser JN, Bae D, Fasching C, Scamurra RW, Ratner AJ, Janoff EN. Antibody-enhanced pneumococcal adherence requires IgA1 protease. PNAS. 2003, 100 (7): 4215-4220. 
World Health Organization (WHO). Pneumococcal vaccines: WHO position paper. Weekly epidemiology record. 1999, 74: 177-183.

Yamamoto M, McDaniel LS, Kawabata K, Briles DE, Jackson RJ, McGhee JR, Kiyono H. Oral immunization with PspA elicits protective humoral immunity against Streptococcus pneumoniae infection. Infect Immun. 1997, 65: 640-644. 